\title{
Dinoflagellates of the Trentino Province, Italy
}

\author{
Gert HANSEN* and Giovanna FLAIM ${ }^{1)}$ \\ Department of Biosciences, Section of aquatic microbiology, University of Copenhagen Øster Farimagsgade 2D, DK-1353 \\ Copenhagen, Denmark \\ ${ }^{1)}$ Natural Resources Department, IASMA Research Centre, 38010 S. Michele all'Adige TN, Italy \\ *corresponding author: gerth@bi.ku.dk
}

\begin{abstract}
The Trentino Province (Italy) has more than 320 lakes diverse in size, geological substrate, altitude and trophic status, and representing most physico-chemical types of temperate lakes. A recent research project (SALTO) offered the opportunity to study the dinoflagellate flora of 27 of these water bodies representing all lake types. In this paper 34 taxa of dinoflagellates assigned to eight genera (Ceratium, Glenodiniopsis, Glochidinium, Gymnodinium, Gyrodinium, Peridinium, Peridiniopsis and Tovellia) in five families (Ceratiaceae, Glenodiniopsidaceae, Gymnodiniaceae, Peridiniaceae and Tovelliaceae) and four genera of uncertain collocation (Baldinia, Borghiella, Durinskia and Staszicella) are described. Two previously undescribed species and two new combinations are also included. Classification is based in part on Popovsky and Pfiester (1990), modified according to the results of recent molecular and ultrastructural analyses. Dinoflagellate taxonomy is currently undergoing extensive revision, and taxonomic decisions in the present article follow the recent orientations in dinoflagellate systematics. The taxonomical issues of the more problematic genera are discussed. Where appropriate, comments on ecological features of the species are also given.
\end{abstract}

Key words: Dinophyceae, morphology, taxonomy, phytoplankton, new species, ecology

\section{INTRODUCTION}

The small Trentino Province in northern Italy (ca. $6300 \mathrm{~km}^{2}$ ) contains more than 320 lakes, but irrespective of its small size perhaps no other area displays such immense lake diversity with respect to size, geological substrate, altitude and anthropogenic inputs (Tomasi 2004). Thus, most types of physico-chemical temperate lake characteristics are represented within this region (Table 1).

Pristine Lake Tovel is probably the best-known Trentino lake, due to its recurrent reddening caused by the dinoflagellate 'Glenodinium sanguineum'. This phenomenon, which essentially has been absent since 1965 , has been a matter of discussion in a number of scientific papers (see e.g. Cavalca et al. 2001). In 2003-2005 a large multidisciplinary project (SALTO) was initiated, which focused on the cause(s) for the disappearance of the reddening of L. Tovel. The results from this project have recently been published (Borghi et al. 2006). An important issue of the project was a detailed characterization of the causative organism and sorting out the taxonomic problems affiliated with this dinoflagellate. It turned out to represent at least 3 different species (Flaim et al. 2004), which have recently been given the scientific names Tovellia sanguinea Moestrup, Gert Hansen, Daugbjerg, Flaim et D'Andrea (formerly known as the red form of ' $G$. sanguineum' and causing the reddening of the lake in the past), Baldinia anauniensis Gert Hansen et Daugbjerg (formerly known as the green form of 'G. sanguineum') and Borghiella dodgei Moestrup, Gert Hansen et Daugbjerg (formerly known as ' $G$. san- guineum' sensu Dodge) (Baldi 1941, Dodge et al. 1987, Moestrup et al. 2006, Hansen et al. 2007, Moestrup et al. 2008).

An issue of relevance to the SALTO project was whether Tovellia sanguinea was endemic to Lake Tovel or also occurred in other lakes of the region. Detailed taxonomic studies of the dinoflagellates had never been made in this region before. It was therefore decided to extend sampling during the SALTO project to include phytoplankton net tow samples for analysis of the dinoflagellate flora in other lakes. The present paper presents the results of this survey.

\section{MATERIAL AND METHODS}

Sampling was done in 27 different lakes in the Trentino Province (Fig. 1, Tab. 1) during 2003 and 2004, as part of the Istituto Agrario's routine sampling programme or during the first author's stay at Istituto Agrario in July-August 2003 and 2004. Some lakes were sampled several times during the study period giving some information on the temporal distribution of the different species. Integrated net samples (10 or $20 \mu \mathrm{m}$ mesh size) were usually collected over the deepest part of the lake to a depth of 2.5 times Secchi disk transparency and fixed in $2 \%$ acidic Lugol. Analysis of live samples was mostly done on July and August samples, and in a few cases on cultured material. Details of the ecological data of the lakes on which Table 1 is based can be found in IASMA (1996-99). Values of total phosphorus $\left(\mathrm{P}_{\mathrm{T}}\right)$ and conductivity at spring overturn were reported as class values. For $\mathrm{P}_{\mathrm{T}}$ class $1=\leq 5 \mu \mathrm{g} \mathrm{l}^{-1}$, class 


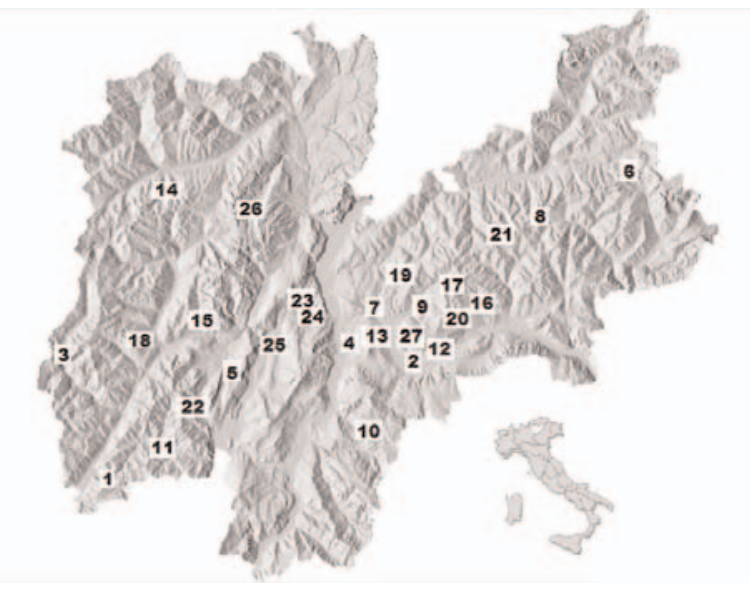

Fig. 1. Sampling localities in the Trentino Province. The numbers correspond to lake numbers of Table 1 .

$2=6-10 \mu \mathrm{g} \mathrm{l}^{-1}$, class $3=11-20 \mu \mathrm{g} \mathrm{l}^{-1}$, class $4=21-35 \mu \mathrm{g}$ $1^{-1}$, class $5=>35 \mu \mathrm{g} \mathrm{l}^{-1}$, for conductivity class $1=<30 \mu \mathrm{S}$ $\mathrm{cm}^{-1}$, class $2=30-80 \mu \mathrm{S} \mathrm{cm}^{-1}$, class $3=80-200 \mu \mathrm{S} \mathrm{cm}^{-1}$, class $4=200-350 \mu \mathrm{S} \mathrm{cm}^{-1}$, class $5=>350 \mu \mathrm{S} \mathrm{cm}^{-1}$.

\section{Light microscopy}

Light microscopy of live or fixed cells was made using Leitz Diaplan, Olympus Provis AX 70 or Olympus BHS microscopes. The microscopes were fitted with a filter arrangement for epifluoresence observations of CalcoFluor White stained cells according to Fritz \& Triemer (1985). Photomicrographs were taken with Leica DFC300FX, Zeiss Axiocam HR or Olympus Camedia 5060 digital cameras.

\section{Scanning electron microscopy}

Fixation for SEM was primarily done in Lugol's as described above. However, unarmoured species were fixed in $2 \% \mathrm{OsO}_{4}$. In either case, cells were placed onto a poly-L-lysine (Sigma) coated circular coverslip. After washing in $\mathrm{dH}_{2} \mathrm{O}$ for one hour, samples were dehydrated in a graded ethanol series: $30 \%, 50 \%, 70 \%, 96 \%$, $99,9 \%$ for $10 \mathrm{~min}$ in each change, and finally in two changes of $100 \%$ ethanol, $30 \mathrm{~min}$ in each change. Sometimes dehydration was stopped in $70 \%$ ethanol and the coverslip was stored at $4{ }^{\circ} \mathrm{C}$ until further processing,

Tab. 1. Physical and trophic characteristics of the Trentino lakes considered. See text for explanation of conductivity and $\mathrm{P}$ class values: $\mathrm{o}=$ oligotrophic, $\mathrm{m}=$ mesotrophic, $\mathrm{e}=$ eutrophic; $\mathrm{n} . \mathrm{a} .=$ not available.

\begin{tabular}{|c|c|c|c|c|c|c|c|}
\hline \multirow{2}{*}{ Lake no. Name } & \multicolumn{4}{|c|}{ physical parameters } & \multicolumn{3}{|c|}{ trophic parameters } \\
\hline & $\begin{array}{c}\text { altitude } \\
\text { m asl }\end{array}$ & $\begin{array}{l}\text { max depth } \\
(\mathrm{m})\end{array}$ & $\begin{array}{l}\text { area } \\
\text { (ha) }\end{array}$ & $\begin{array}{c}\text { volume } \\
10^{3} \mathrm{~m}^{3}\end{array}$ & $\begin{array}{c}\text { conductivity } \\
\text { class }\end{array}$ & $\begin{array}{l}\mathrm{P}_{\text {tot }} \\
\text { class }\end{array}$ & trophy \\
\hline 1 Ampola & 725 & 5 & 6 & n.a & 5 & 3 & m-e \\
\hline 2 Caldonazzo & 449 & 49 & 563 & 148,987 & 4 & 4 & $\mathrm{~m}$ \\
\hline 3 Campo & 1943 & 27 & 9 & 1,130 & 2 & 2 & o \\
\hline 4 Canzolino & 540 & 15 & 7 & 515 & 4 & 5 & $\mathrm{e}$ \\
\hline 5 Cavedine & 241 & 50 & 101 & 24,492 & 3 & 3 & $\mathrm{o}-\mathrm{m}$ \\
\hline 6 Colbricon & 1926 & 12 & 3 & 163 & 2 & 2 & $\mathrm{o}-\mathrm{m}$ \\
\hline 7 Colomba, Santa & 922 & 9 & 3 & 129 & 3 & 3 & $\mathrm{~m}$ \\
\hline 8 Lagorai & 1868 & 31 & 9 & 1,433 & 1 & 2 & o \\
\hline 9 Lases & 632 & 26 & 12 & 1,750 & 3 & 3 & $\mathrm{~m}$ \\
\hline 10 Lavarone & 1100 & 17 & 5 & 383 & 4 & 4 & m-e \\
\hline 11 Ledro & 655 & 48 & 218 & 75,775 & 4 & 2 & $\mathrm{~m}$ \\
\hline 12 Levico & 440 & 38 & 116 & 12,942 & 4 & 3 & $\mathrm{~m}$ \\
\hline 13 Madrano & 548 & 8 & $<1$ & 31 & 5 & 4 & $\mathrm{e}$ \\
\hline 14 Malghette & 1891 & 12 & 10 & 477 & 1 & 1 & o \\
\hline${ }_{15}$ Molveno - & & 124 & 341 & 161,200 & 2 & 2 & o \\
\hline 15 Bior & 845 & 4 & 1 & n.a. & 4 & 4 & $\mathrm{e}$ \\
\hline 16 Piazze & 1025 & 30 & 36 & 6,080 & 2 & 3 & $\mathrm{~m}$ \\
\hline 17 Rane & 700 & 1 & $<1$ & n.a & 1 & 5 & $\mathrm{~m}$ \\
\hline 18 Roncone & 782 & 4 & 3 & 55 & 5 & 4 & $\mathrm{e}$ \\
\hline 19 Santo di Cembra & 1194 & 15 & 3 & 192 & $2-3$ & 3 & $\mathrm{~m}$ \\
\hline 20 Serraia & 974 & 17 & 44 & 3,140 & 3 & 5 & $\mathrm{e}$ \\
\hline 21 Stellune & 2099 & 20 & 3 & n.a & 2 & 1 & o \\
\hline 22 Tenno & 570 & 48 & 20 & 3,904 & 4 & 2 & $\mathrm{o}-\mathrm{m}$ \\
\hline 23 Terlago north & & 10 & & & & 4 & $\mathrm{e}$ \\
\hline 24 Terlago south & 414 & 2 & 12 & 445 & 5 & 5 & $\mathrm{e}$ \\
\hline 25 Toblino & 245 & 14 & 73 & 5,900 & 3 & 3 & $\mathrm{~m}$ \\
\hline 26 Tovel & 1178 & 39 & 38 & 7,368 & 4 & 2 & o \\
\hline 27 Valle & 625 & 8 & 2 & 72 & 4 & 4 & $\mathrm{~m}$ \\
\hline
\end{tabular}


usually within a month. Critical point drying was made using a BAL-TEC CPD-030. The filters or coverslips were mounted on stubs and coated with palladium-platinum and examined using a JEOL JSM-6335F field emission scanning electron microscope.

\section{Taxonomic considerations}

The taxonomy used in the present study follows, to some extent Popovský \& Pfiester (1990). However, the taxonomy and phylogeny of freshwater dinoflagellates is currently under rapid development. Based on recent molecular- and ultrastructural analyses some groups have been revised or are likely to be in the near future. For example Gymnodinium helveticum has been transferred to the genus Gyrodinium (Takano \& Horiguchi 2004). The woloszynkioid dinoflagellates have been shown to represent several lineages, which so far has resulted in the creation of the new family Tovelliaceae, with Tovellia coronata and T. sanguinea as well-known members (Lindberg et al. 2005; Moestrup et al. 2006). With respect to the peridinioids a major revision is still awaited, but their relatively high diversity in plate tabulation suggests that they will probably be divided into several new genera in the future. The number of cingular plates has been considered an important generic criterion; e.g. the genus Protoperidinium was separated from Peridinium based on the presence of 4 and 5 cingular plates, respectively (Balech 1974). Similarly, the presence of 6 cingular plates distinguishes the marine genus Scrippsiella from Peridinium (Balech 1980). However, several freshwater Peridinium species have 6 cingular plates; i.e. the palatinum-, lomnickii- and umbonatum-groups. Molecular evidence has shown that at least the lomnickii-group is closely related to Scrippsiella (Logares et al. 2007 for P. aciculiferum and Niels Daugbjerg \& Gert Hansen, unpubl. obs. for P. lomnickii). The umbonatum-group has only 2 rather than 3 intercalary plates, and seems to be related neither to Peridinium nor the Scrippsiella/lomnickii-group based on SSU rDNA phylogeny (Logares et al. 2007). The palatinum-group belongs to the subgenus Cleistoperidinium (i.e. an apical pore is lacking), but the presence of 6 cingular- and only 2 anterior intercalary plates, indicates that the palatinum-group is only distantly related to the cinctum-, willei- and striolatum-groups of the cleistoperidinioids.

Another large genus is Peridiniopsis. According to Bourrelly's (1968) revision, this genus is defined as peridinioids either lacking or having only one anterior intercalary plate (1a). This includes species with plate formulas: 3-5', 0-1a (2a), 6-8", 5"', 2"”. However, this clearly seemed to be an oversimplification. The number of cingular plates within this group varies from 3 to 6 . Thus, $P$. penardiforme has only 3 cingulars and Boltovskoy (1999) created the genus Glochidinium to accommodate this species. Peridiniopsis penardii and $P$. kevei have 5 cingular plates, but molecular and ultrastructural data show that these two species are closely related, e.g. both have a diatom endosymbiont and an eyespot bound by 3 membranes, type $\mathrm{D}$ eyespot sensu Moestrup \& Daugbjerg (2007), and will probably need to be transferred to a genus of their own (Takano et al. 2008). Peridiniopsis occulata also has 5 cingular plates and its plate tabulation and arrangement are exactly the same as in the brackish water species Durinskia baltica, and it has been transferred to this genus in the present study. A number of species, including the type $P$. borgei have 6 cingular plates, but differ in the numbers of apical- (3-5) or precingular plates (6 or 7). The relationships of these species, particularly of $P$. borgei, await molecular analyses. However, P. polonica seems to be related to Scrippsiella based on a SSU rDNA phylogeny (Logares et al. 2007).

\section{RESULTS AND DISCUSSION}

\section{Family Gymnodiniaceae (Bergh) Schütt}

Cells are unarmoured, i.e. no visible traces of thecal plates can be seen at the light microscope level. The family comprises species with or without chloroplasts, and is, as presently defined, polyphyletic (see also Daugbjerg et al. 2000, Saldarriaga et al. 2004).

\section{Gymnodinium aeruginosum Stein (Figs 2A-B).}

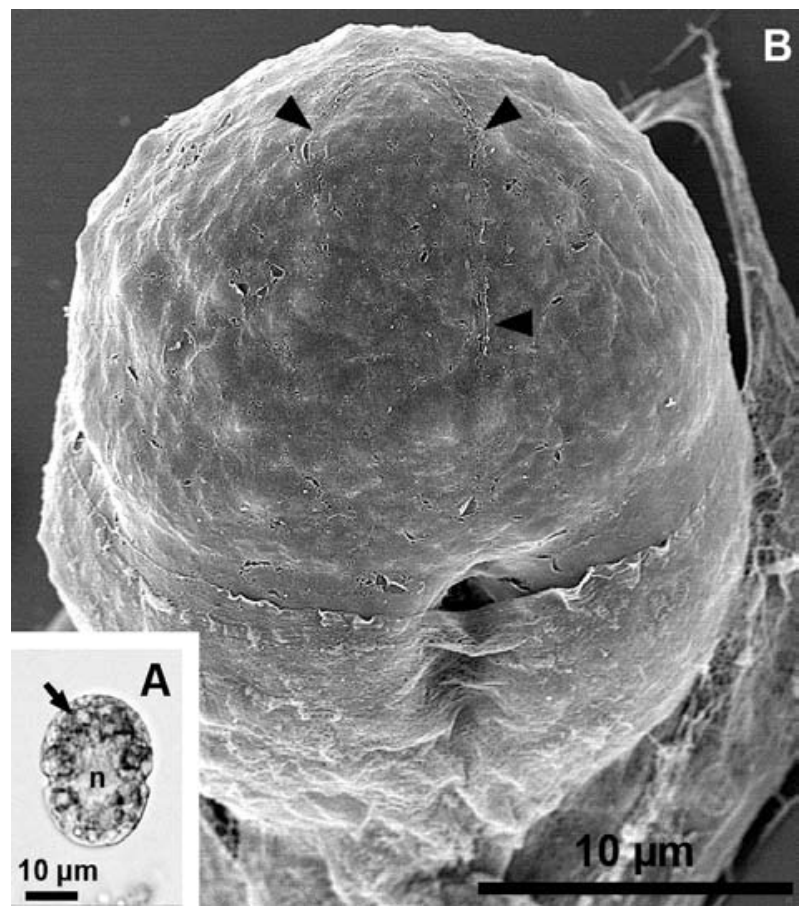

Figs 2A, B. Gymnodinium aeruginosum. A. Light microscopy (LM) of a live cell, chloroplasts (arrow), nucleus (n). B. SEM, the apical groove is marked by arrowheads. 
The cell is more or less ovoid, with hemispherical epi- and hyposome. The cingulum is not displaced and is usually slightly sub-median, i.e. the episome is slightly larger than the hyposome. A 'fish-hook'-shaped apical groove running in an anticlock-wise direction is present. Numerous, distinctly blue-green chloroplasts are present and the nucleus is situated in the central part of the cell. No eyespot is present. Length: $28-30 \mu \mathrm{m}$; width: 22-24 $\mu \mathrm{m}$. Cells often immobile and imbedded in mucilage, making SEM preparation difficult.

Distribution. Only found in Ampola pond in July, where it was quite abundant.

Comments. Often restricted to smaller neutral or slightly acidic ponds, with rich macrophyte vegetation
The nucleus is located in the episome, slightly above the cingulum. Cells are often lying immobile in mucilage. Length: $70-80 \mu \mathrm{m}$, width: $45-50 \mu \mathrm{m}$.

Distribution. Only found in Rane pond in July.

Comments. The resting cyst of this species is round with a characteristic outer wall with ridges arranged in a hexagonal pattern (e.g. Hansen et al. 2000). In our survey, this dinoflagellate was only found in a slightly acidic pond, confirming Höll's (1928) observation that it is often found in Sphagnum-bogs and seems to prefer slightly acidic conditions and low calcium concentrations. G. fuscum is the type species of the genus Gymnodinium and its ultrastructure was studied in detail by Hansen et al. (2000). They found it to be quite dif-
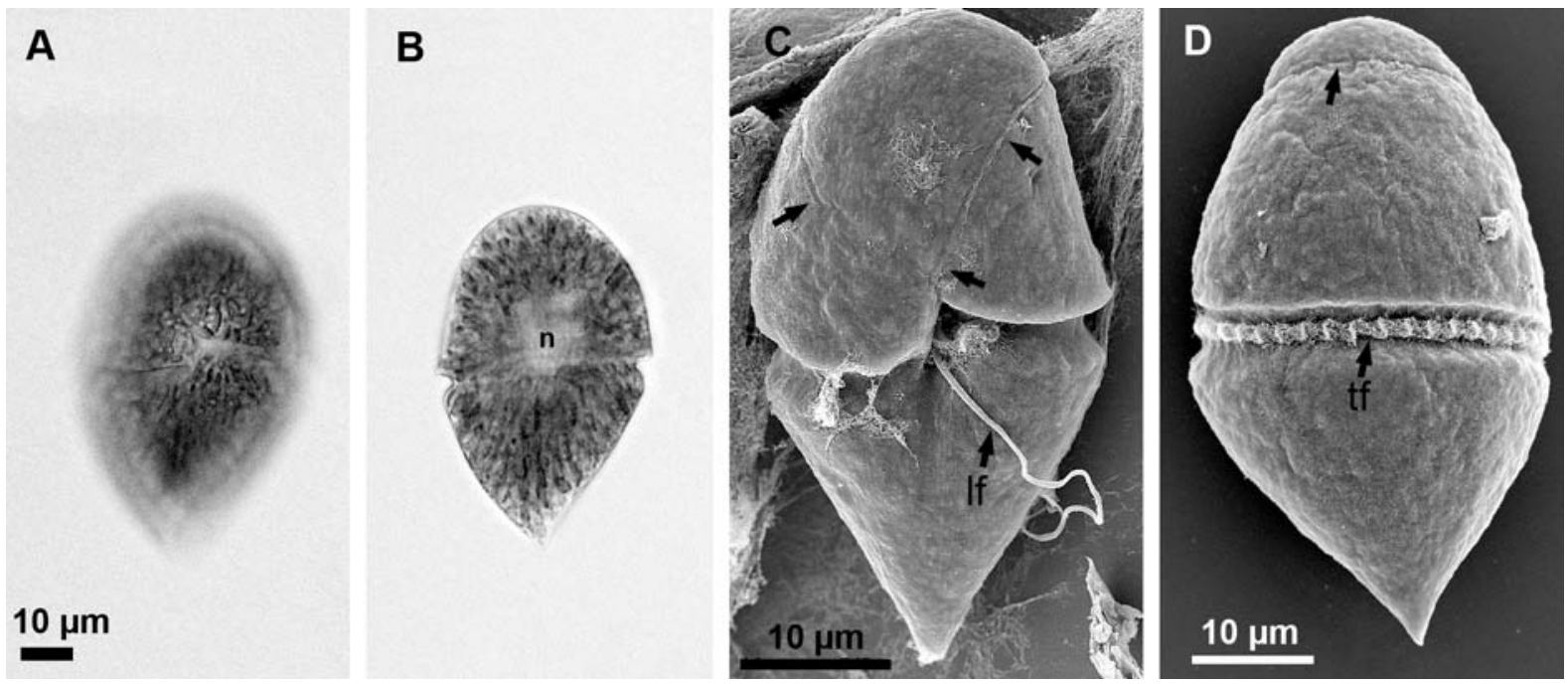

Figs 3A-D. Gymnodinium fuscum. A-B. LM of a live cell, high and low focus, respectively. C-D. SEM, ventral and dorsal views, respectively. The apical groove is marked by arrows. tf: transverse flagellum; lf: longitudinal flagellum.

(Huber-Pestalozzi 1968). Ampola pond meets the first of these criteria but has a rather high conductivity (Tab. 1). The ultrastructure has been studied in some detail by (Schnepf et al. 1989) and revealed a cryptophyte affinity of the chloroplasts, but whether they represent permanent endosymbionts or rather 'kleptochloroplasts' is not known. The present material differs from Stein's (1883) original description by not being dorso-ventrally flattened. It can be confused with G. acidotum Nygaard, but this species has a pointed hyposome.

\section{Gymnodinium fuscum (Ehrenberg) Stein (Figs 3A-D).}

The cell has a hemispherical episome and a distinctly pointed conical hyposome that sometimes is furnished with a more or less pointed hyaline protrusion (not shown). The cingulum is median and displaced one cingular width. A delicate horseshoe-shaped apical groove is present. The cell contains numerous brownish chloroplasts arranged in a somewhat radiating pattern. ferent from other Gymnodinium species sensu Daugbjerg et al. (2000), based on features of the flagellar apparatus.

\section{Gymnodinium mirabile Penard (Figs 4A-E).}

The cell is ovoid, the episome being hemispherical and the hyposome is usually more flattened. The cingulum is median or slightly submedian. The sulcus is narrow extending onto the episome in a straight course. The apical groove is anticlockwise and almost circular. Its distal end nearly reaches its proximal end. The cell contains numerous chloroplasts arranged in a somewhat radiating pattern. Their colour is variable ranging from yellowish green to brown. These are often restricted to the central part of the cell leaving a distinct hyaline border along the periphery, where rod-shaped bodies are situated. A distinct circular pusule is situated in the central part of the cell. No eyespot is present. Motile division pairs are quite common. The nucleus is large and typically wider than long, but its shape and position within 

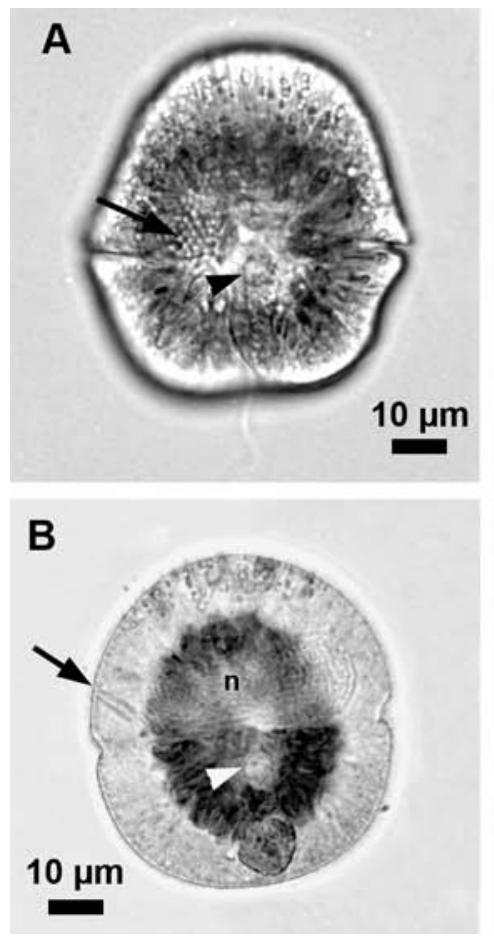
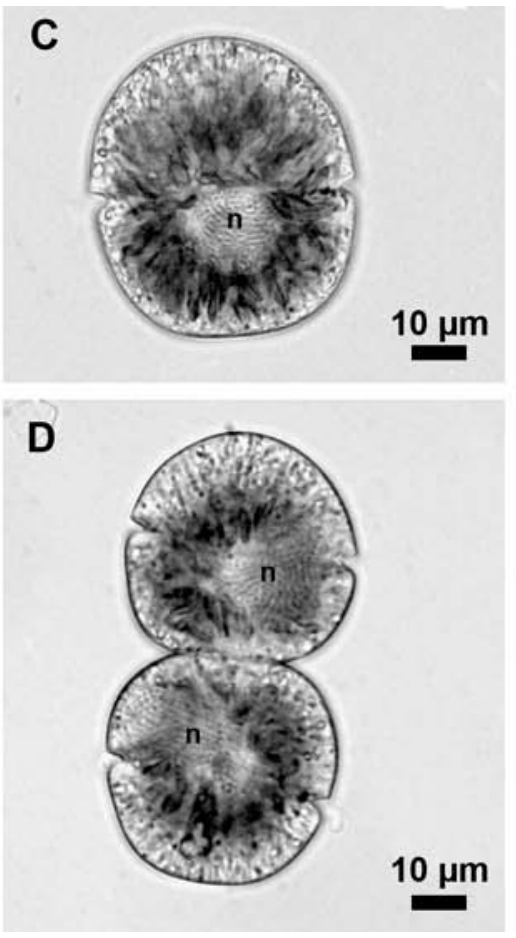

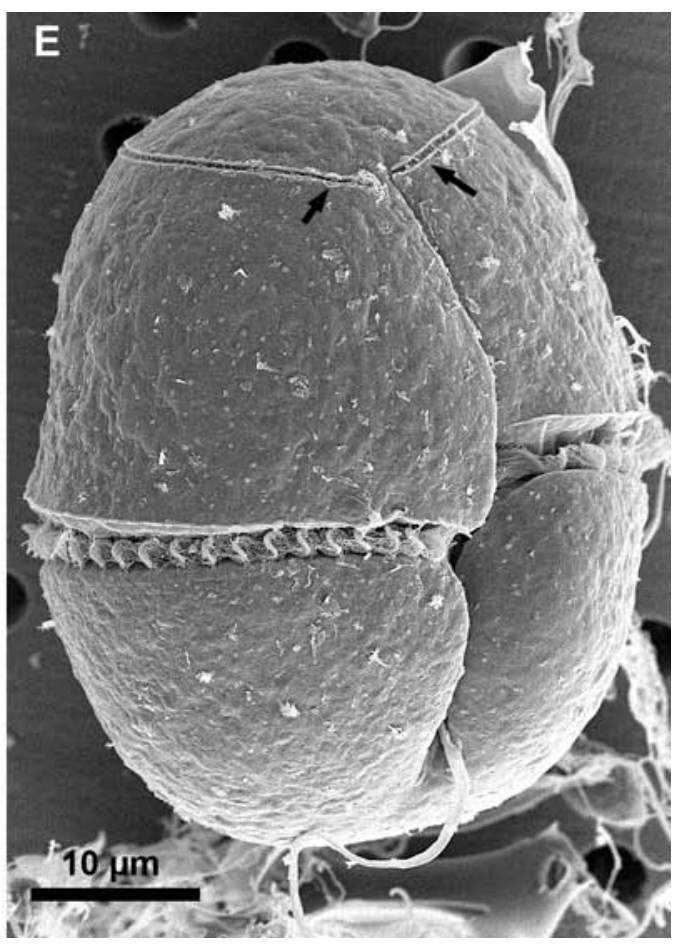

Figs 4A-E. Gymnodinium mirabile. A-D. Light microscopy of live cells. Notice peripheral rod-shaped bodies (arrow) and pusule (arrowhead). Fig. D shows a division pair. E: SEM, ventral view, apical groove (arrows).

the cell is quite variable, which could be due to the division mode. Thus, the nucleus always seems to be situated in the hypo- or episome of the top- and bottom cell of a division pair, respectively. Length: $68-48 \mu \mathrm{m}$; width $62-46 \mu \mathrm{m}$. The length/width ratio is typically slightly above one but can also be as high as 1.3.

Distribution. Colbricon (July), Colomba (July), Levico (July), Santo (July), Tenno (July) and Tovel (June, July, August).

Comments. Some confusion on the identity of this species exists since it was brought into synonymy with G. uberrimum (Allmann) Kofoid et Swezy by Popovský $\&$ Pfiester (1990). However, according to the original description of Allmann $(1854,1855$, as Peridinium uberrima Allmann) G. uberrimum differs in several aspects from G. mirabile. It is considerably smaller, 25-50 $\mu \mathrm{m}$ in dia., though the upper range is still within the lower range of G. mirabile. But more importantly its shape is quite different. The episome is conical rather than hemispherical and the hyposome has a distinct antapical indentation. Also no pusule was depicted, a feature that is very distinct in $G$. mirabile and seems unlikely to have been overlooked by Allman, as he emphasised the presence of numerous minute oil-drops. Finally, G. uberrimum was described from a large park pond in Ireland, where it caused discolouration of the water, whereas $G$. mirabile was originally described from the alpine Lac Léman in Switzerland (Penard 1891).
The present material fits the original description of G. mirabile, except that its size is generally smaller. Penard (1891) noted that the presence of an eyespot was rare and is not included in his illustrations. We never observed an eyespot, and it seems likely what Penard interpreted as an eyespot could have been a red inclusion body. He also distinguished between G. mirabile and G. mirabile var. rufescens, the latter differing by its smaller size measuring only $45 \mu \mathrm{m}$ in length and $40 \mu \mathrm{m}$ in width. This variety was later raised to species by Lemmermann (1910) as G. rufescens Lemmernann. However, we consider them as similar species. The smaller size of var. rufescens being due to recent cell division and does not justify varietal status. G. mirabile seems to be a 'summer-species' restricted to sub-alpine or alpine oligotrophic lakes (Huber-Pestalozzi 1968), but has also been found outside the Alps e.g. in certain mountain lakes of Japan (Senzaki \& Horiguchi 1994). While our findings confirm that it is a summer species, G. mirabile was not restricted to oligotrophic lakes but can also be found in mesotrophic environments (e.g. Levico and Santo, Table 1).

\section{Gymnodinium obesum Schiller (Figs 5A-C).}

The cell is ovoid with a median cingulum that is displaced nearly one cingular width. The sulcus is narrow and deep and only reaches about halfway down the hyposome. It deflects to the left on its entry onto the episome and continues in a somewhat sigmoid manner before making an anticlockwise loop around the cell's 


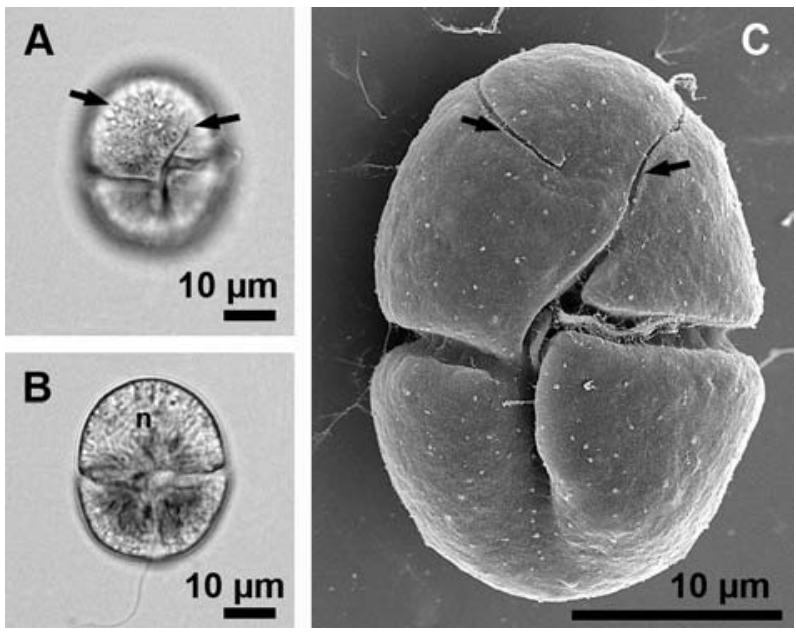

Figs 5A-C. Gymnodinium obesum. A, B. Live cell, high and low focus, respectively. Apical groove (arrows). C. SEM, ventral view.

apex - a horseshoe-shaped apical groove. The nucleus is situated in the episome (but see below). The yellowish chloroplasts are elongated and often situated in the central part of the cell, but individuals with more evenly distributed chloroplasts have occasionally been observed (not shown). No eyespot is present. One or more red accumulation bodies (or food vacuoles?) may be present in the hyposome (not shown). Length: 30-37 $\mu \mathrm{m}$, width: $26-30 \mu \mathrm{m}$.

Distribution. Found in Caldonazzo, Colbricon, Lavarone, Levico and Malghette all in July.
Comments. Schiller (1933) originally described this species in summer samples from L. Attersee in Austria, indicating that it is a warm water species. This characteristic was confirmed in our survey and the dinoflagellate is also common in certain Danish lakes during the summer period, further supporting Schiller's (1933) observations. Although his description is relatively scanty, its distribution, the characteristic shape of the sulcus, and the cell shape fit with the present material. This species very much resembles Gymnodinium mirum Utermöhl with respect to the location of the nucleus and the left displacement of the sulcus on the episome. Both species also appear to be restricted to the summer period (Utermöhl 1925). However, G. mirum has a conical hyposome, a sulcus reaching the antapex, numerous small chloroplasts and delicate plates (Utermöhl 1925). Due to the latter feature it was transferred to the genus Woloszynskia by Kisselev (1954) (as W. mira (Utermöhl) Kisselev). However, plates were not depicted by Utermöhl and have to our knowledge never been verified. Gymnodinium mirum sensu Nygaard (1949) most likely represents $G$. obesum, due to the characteristic sulcus deflecting to the left on the episome and not reaching the antapex. Variation in the position of the nucleus (episomal to central) has been observed (Gert Hansen unpubl. obs.). Another very similar species is $G$. limitatum Skuja, but in this species the sulcus also reaches the antapex and the nucleus is sometimes furnished with a distinct outer layer (Skuja 1956), a feature that has never been observed in the present material or in Danish lakes.
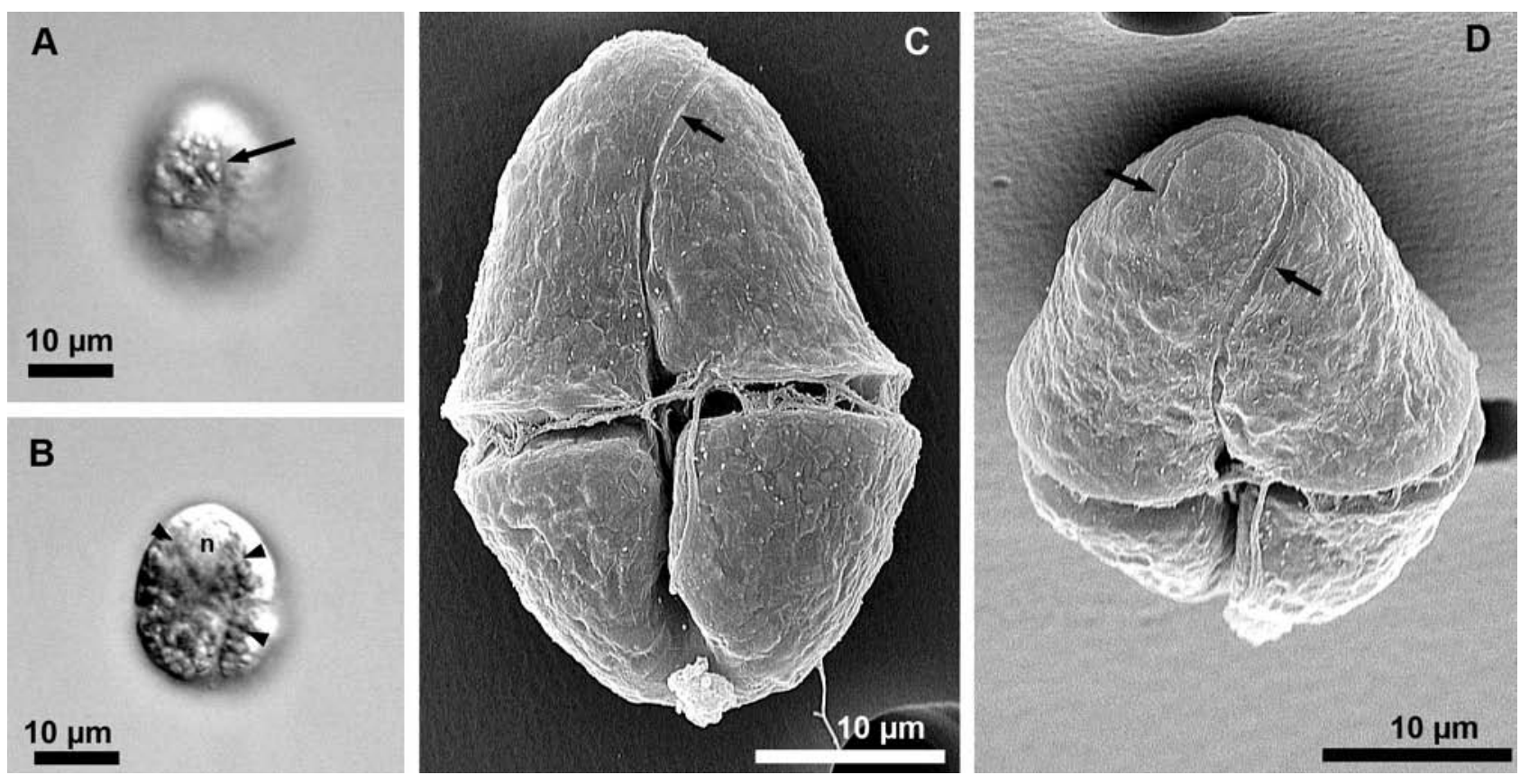

Figs 6A-D. Gymnodinium palustriforme sp. nov. A, B. Live cell, high and low focus, respectively. Sulcal extension (arrow); chloroplast(s) (arrowheads). C, D. SEM, ventral and apical views, respectively. Apical groove (arrows). 


\section{Gymnodinium palustriforme sp. nov. Gert Hansen et Flaim (Figs 6A-D).}

Latin diagnosis: Cellula elliptica vel ovata inter dorsum et ventrem complanata. Epitheca campanae forma et latior hypotheca hemisphaerica. Cingulum submedianum non amotum, nisi leviter. Sulcus angustus altusque, sed extenditur antequam partem antapicalem contingat. Continuatur lineariter parum plus quam media parte usque ad epithecam sic ut in canaliculum apicale, quod cellulae apicem circumdat, vertatur. Chloroplastus flavovirens leviter irregularis radiansque a parte media ad superficiem.

Nucleus sphaericus in epitheca situs. Stigma non est. Longae $35 \mu \mathrm{m}$, latae $25 \mu \mathrm{m}$ (cellulae parvae $22 \mu \mathrm{m} \times 17 \mu \mathrm{m}$ ).

Holotypus: Figs 6B, C.

Etymology: palustriforme 'form like palustre' as this species is very similar to G. palustre.

The cell is elliptical or ovoid and dorso-ventrally flattened. The episome is bell-shaped and longer than the hemispherical hyposome. The submedian cingulum is not or only slightly displaced. The sulcus is narrow and deep but widens slightly before reaching the antapex. It continues in a straight manner a little over halfway onto the episome and then transforms into a 'fishhookshaped' apical groove that partly encircles the cell's apex. The yellowish green chloroplast(s) is somewhat irregularly shaped and radiating from the central part of the cell towards the surface. The rounded nucleus is situated in the episome. No eyespot is present. Length: c. 35 $\mu \mathrm{m}$, width c. $25 \mu \mathrm{m}$ (small cells: $22 \mu \mathrm{m} \times 17 \mu \mathrm{m}$ ).

Distribution. Only observed in L. Tovel, the present material originates from a culture established from a water sample collected in November, but cells with a similar shape have also been observed in preserved samples collected in January.

Comments. This species is very similar to G. palustre Schilling, but does not have numerous parietal chloroplasts (Schilling 1891). Also G. palustre is generally considered as a summer species restricted to oligotrophic localities with relatively low $\mathrm{pH}$ and calcium levels, e.g. lakes with a granite watershed (Höll 1928). On the contrary $G$. palustriforme is unable to grow at temperatures above $12{ }^{\circ} \mathrm{C}$ and seems to be a coldwater
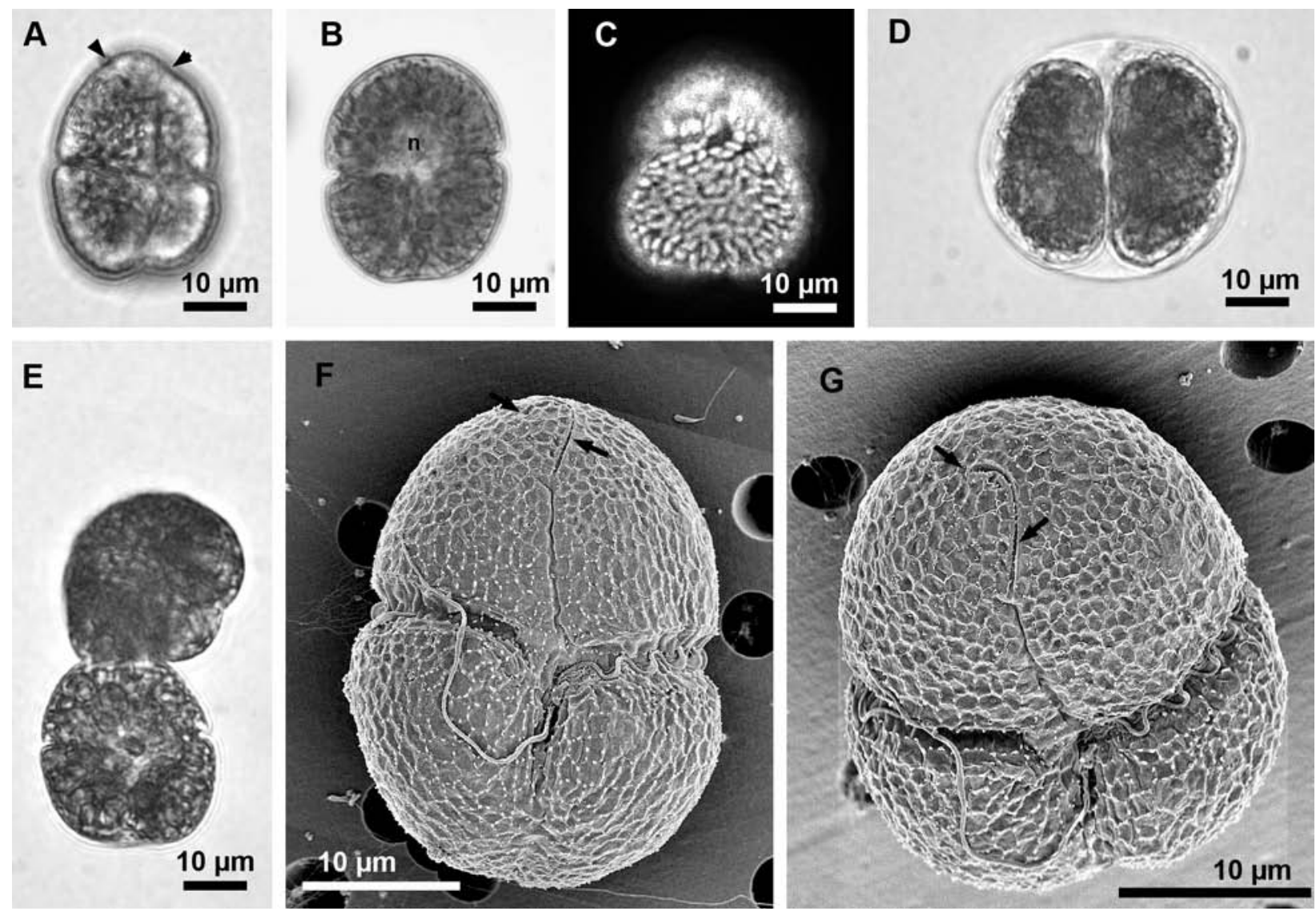

Figs 7A-G. Gymodinium pseudomirabile sp. nov. A-E. Live cells. A. The apical groove is barely visible (arrowheads). B. The typical cell shape. C. Fluoresence microscopy revealing the auto fluorescence of numeous chloroplasts. D. Division cyst. E. Division or fusing pairs. F, G. SEM, ventral and ventral-apical views, respectively. Apical groove (arrows). 
species. Furthermore, the $\mathrm{pH}$ and calcium levels of $\mathrm{L}$. Tovel are fairly high as the catchment area is dominated by dolomite and limestone (e.g. Corradini et al. 2001).

\section{Gymnodinium pseudomirabile}

\section{sp. nov. Gert Hansen et Flaim (Figs 7A-G).}

Latin diagnosis: Cellulae forma ovata, inter dorsum et ventrem complanata. Epitheca et hypotheca hemisphaericae, hypotheca cum minuta antapicali carina (indentatione). Cingulum medium et non amotum. Sulcus angustus et parum altus, non extensus ad punctum antapicale. Extenditur circiter duas partes ad epithecam et continuatur ad canaliculum apicalem in hami forma. Nucleus sphaericus, in media parte situs et leviter praemedianus. Plures chloroplasti virides fuscique radiantes usque ad cellulae partem mediam. Stigma non est. Divisionis cystae cellulaeque geminae interdum observatae.

Holotypus: Fig. 7F.

Etymology: 'pseudomirabile' the false G. mirabile.

The cell shape is ovoid and slightly dorso-ventrally flattened. The epi- and hyposome are hemispherical, the latter with a minute antapical indentation. The cingulum is median and not displaced. The sulcus, which is narrow and shallow, does not reach the antapex. It extends about $2 / 3$ onto the episome and continues into a "fish- hook-shaped' apical groove. The rounded nucleus is situated centrally and is slightly premedian. The cell contains numerous greenish-brown chloroplasts that radiate towards the centre of the cell. No eyespot is present. Division cysts and cells in pairs were occasionally observed. Length: 31-36 $\mu \mathrm{m}$, width: $28-31 \mu \mathrm{m}$.

Distribution. Culture established from sample collected in L. Tovel in November.

Comments. This species superficially resembles $G$. mirabile, which also has cells swimming in pairs. This feature is puzzling in G. pseudomirabile, as it also possessed division cysts and two different divisional modes within the same species are very unusual. Alternatively, the cell pairs could represent a mating event. $G$. pseudomirabile differs from G. mirabile by its smaller size, lack of cingular displacement and most importantly a different apical groove. It also has a different distribution as $G$. mirabile is a summer species, whereas $G$. pseudomirabile appears to be an autumn or winter species, although it grows quite well at $15{ }^{\circ} \mathrm{C}$. It has some resemblance to G. palustriforme and G. palustre, but is less dorso-ventrally flattened and has a median rather that a sub-median cingulum. Interestingly, they all share the same fishhook-type of apical groove as does G. aeruginosum indicating a close relationship (Gert Hansen unpubl. obs for G. palustre).
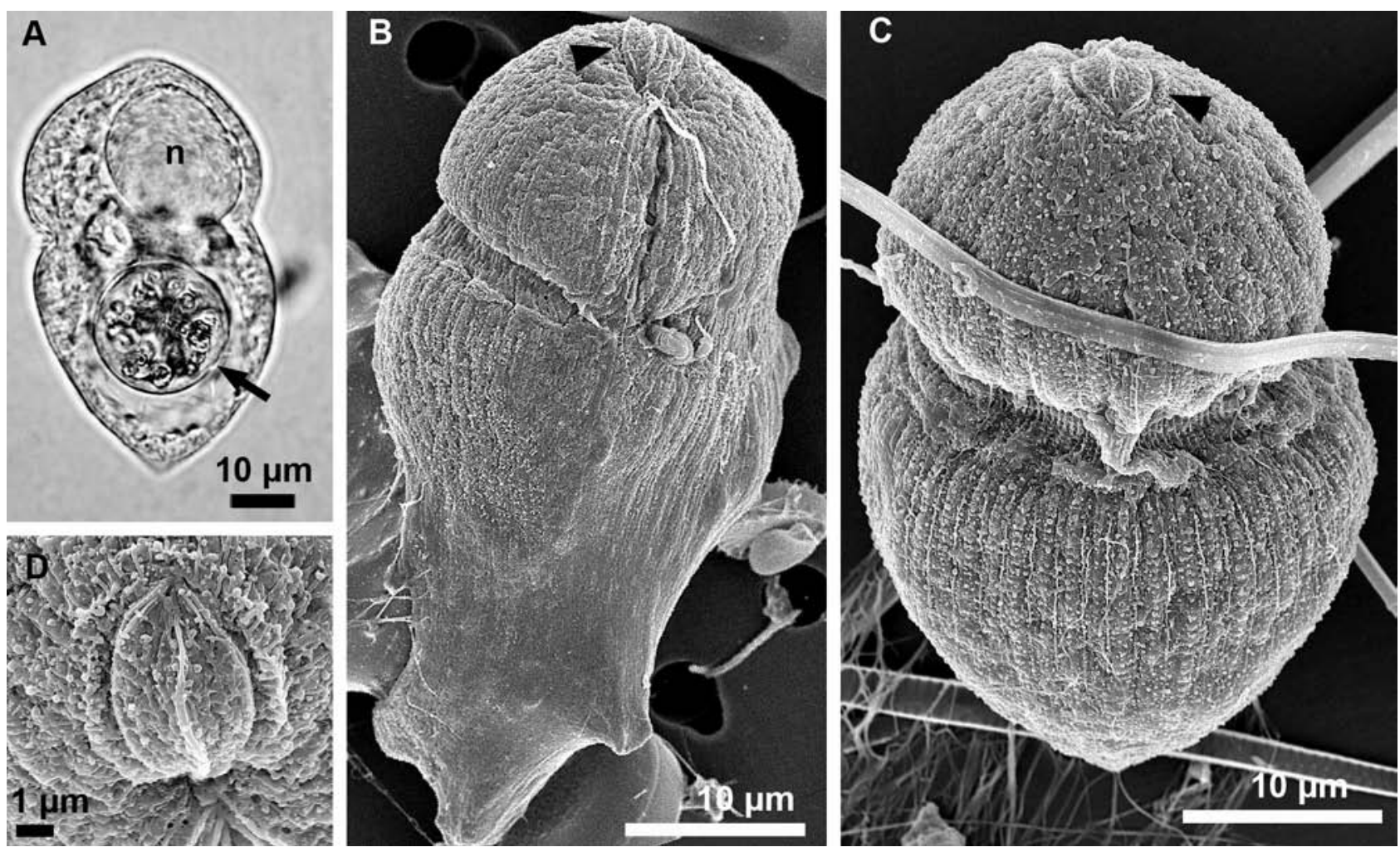

Figs 8A-D. Gyrodinium helveticum. A. LM of fixed cell, food vacuole (arrow), nucleus (n). B-D. SEM, ventral and dorsal views, respectively. Apical groove arrowhead. B. Ingested prey is causing the distorted hyposome of this cell. D. Apical groove at higher magnification. 


\section{Gyrodinium helveticum \\ (Penard) Takano et Horiguchi (Figs 8A-D).}

The cell is elongated with a hemispherical episome furnished with an elliptical apical groove that is bisected by a central ridge, an arrangement that sometimes may be seen as three small 'spines'. The hyposome is conical and at least 1.5 times longer than the episome. The cingulum is not displaced. The sulcus is narrow and extends onto the episome. Numerous surface ridges are present. The colour of the cell sometimes has a pinkish tinge. The nucleus is large and usually situated in the episome. Chloroplasts are absent. The cells shape and length are extremely variable due to ingestion of prey organisms, often diatoms, but also other unidentifiable prey items. Length: 56-71 $\mu \mathrm{m}$, width: 33-55 $\mu \mathrm{m}$ (measurements based on fixed material).

Distribution. Canzolino (March, May), Caldonazzo (March), Lases (April), Lavarone (April, March, July), Madrano (March), Tovel (all year round).

Comments. Höll (1928) considered it to be a cold water species that only occurs during the winter in shallow lakes, but could also occur during the summer in lakes with a permanently cold deep layer. This is for example the situation in L. Tovel, where it is euplanktonic all year round (Flaim et al. 2003). G. helveticum var. apiculatum (Zacharias) Utermöhl differs by the lack of the 3 apical 'spines' (Utermöhl 1925), while G. helveticum f. achroum Skuja differs by being colourless (Skuja 1948). However, considering the great variability in morphology and colour these varieties and forma seem meaningless. The food uptake was studied by Popovský (1982) and seems to involve a 'lobopode' extruding from the sulcus. Its affinity to Gyrodinium rather than Gymnodinium has been confirmed recently by molecular data (Takano \& Horiguchi 2004).

\section{Family Tovelliaceae Moestrup, Lindberg et Daugbjerg}

Dinoflagellates with an eyespot not bound by any membranes, type $\mathrm{C}$ eyespot sensu Moestrup \& Daugbjerg (2007). Chloroplasts present or absent. Usually a thin theca consisting of many plates and an apical line of narrow plates as in e.g. Tovellia (Lindberg et al. 2005)

\section{Tovellia sanguinea Moestrup, Gert Hansen, Daugbjerg, Flaim et D'Andrea (Figs 9A-I).}

The cell is bright red due to the presence of numerous red-pigmented bodies. The epi- and hyposome are usually conical but might also be hemispherical. The episome is often slightly larger than the hyposome. The cingulum is displaced one cingular width. The yellowish green chloroplast(s) radiates from the central part of the cell, but the presence of pigment bodies often masks the chloroplast. A distinct red eyespot is situated in the sulcus. The theca consists of many polygonal plates that are visible in LM using oil-immersion and phase contrast (not shown), and are easily observed using SEM. An apical line of plates (ALP) is present. Length: 22-32 $\mu \mathrm{m}$, width: $15-28 \mu \mathrm{m}$, but putative gametes measuring $12-15 \mu \mathrm{m}$ in length and planozygotes measuring up to $43 \mu \mathrm{m}$ in length have been observed in old or ageing cultures.

The resting cyst is bipolar with a paracingulum that usually is bounded with numerous knobs (not shown).

Distribution. Campo (August), Colbricon (July), Lases? (July), Tovel (June to October).

Comments. This species is the organism responsible for the cyclic reddening of L. Tovel in the past (see e.g. Cavalca 2001, and references therein). It usually was referred to as Glenodinium sanguineum Marchesoni, but this is a homonym of another species, G. sanguineum (H.J. Carter) Diesing (see Moestrup et al. 2006). Species of the newly erected family Tovelliaceae are characterised by an eyespot that is not bound by any membranes or located inside a chloroplast. The genus Tovellia is characterised by the bipolar cyst and the presence of an ALP (Lindberg et al. 2005). Tovellia sanguinea is closely related to $T$. coronata (Woloszyńska) Lindberg, Moestrup et Daugbjerg, but differs genetically and by having a compound pyrenoid, fewer but larger pigment bodies and a peculiar thickened antapical plate (Moestrup et al. 2006). The material from Campo, Colbricon, and Tovel have been verified to represent the same species based on analysis of the large ribosomal DNA gene (Moestrup et al. 2006), while the morphotype from Lases has only been observed by SEM of fixed material.

It is notable that the distribution of $T$. sanguinea includes quite different lakes with respect to geological substrate, conductivity and trophic status (Table 1), but only in Tovel did it occur in bloom concentrations in the past.

\section{Family Glenodiniopsidaceae Schiller}

Cells with plate formula: 2-9', 0-4a, 6-12", c, s, 512", 0-2p, 1-2"'" (Schiller 1937).

\section{Glenodiniopsis uliginosa (Schilling) Woloszyńska (Figs 10A-D).}

The cell is ovoid with rounded epi- and hyposome. The episome is longer and slightly wider than the hyposome. The cingulum is relatively deep and displaced one cingular width. The greenish brown chloroplast(s) were difficult to observe due the presence of numerous corpuscles, but seemed to be restricted to the central part in most cells. The nucleus was elongated and located ecentrically in the right part of the episome (not shown). No eyespot was present. The plate pattern was not visible in LM, but in SEM the plate tabulation became evident. Highfill \& Pfiester (1992) found the plate tabulation to 

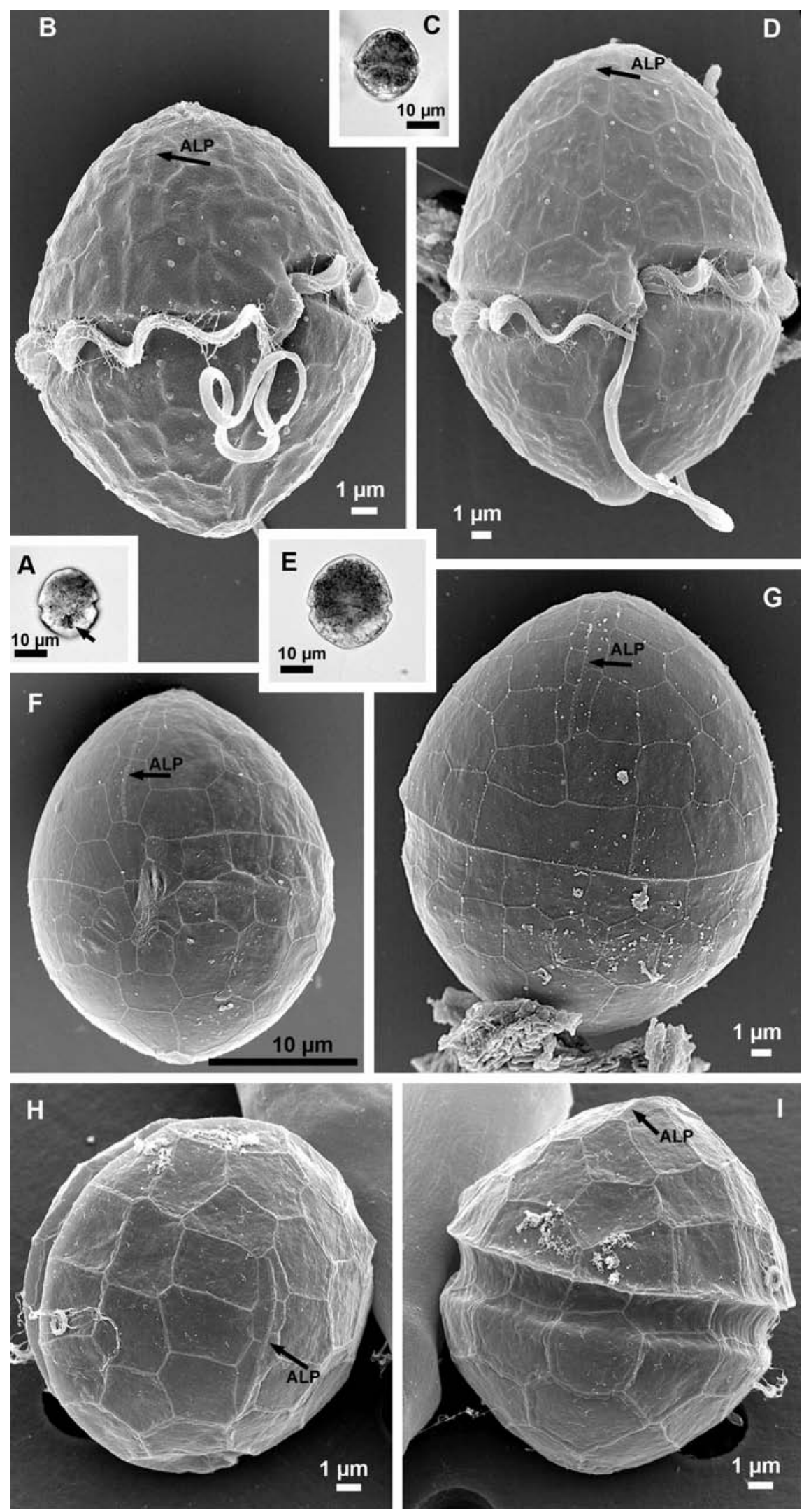

Figs 9A-I. Tovellia sanguinea. A, B. Cells from L. Tovel; LM and SEM, respectively. Eyespot (arrow); ALP: apical line of plates. C, D. Cells from L. Campo, LM and SEM, respectively. E-G. Cells from L. Colbricon. E: LM. F, G: SEM, ventral and dorsal view, respectively. Notice the cells have swollen during the fixation procedure. H, I. Cells from L. Lases, apical and dorsal views, respectively. 

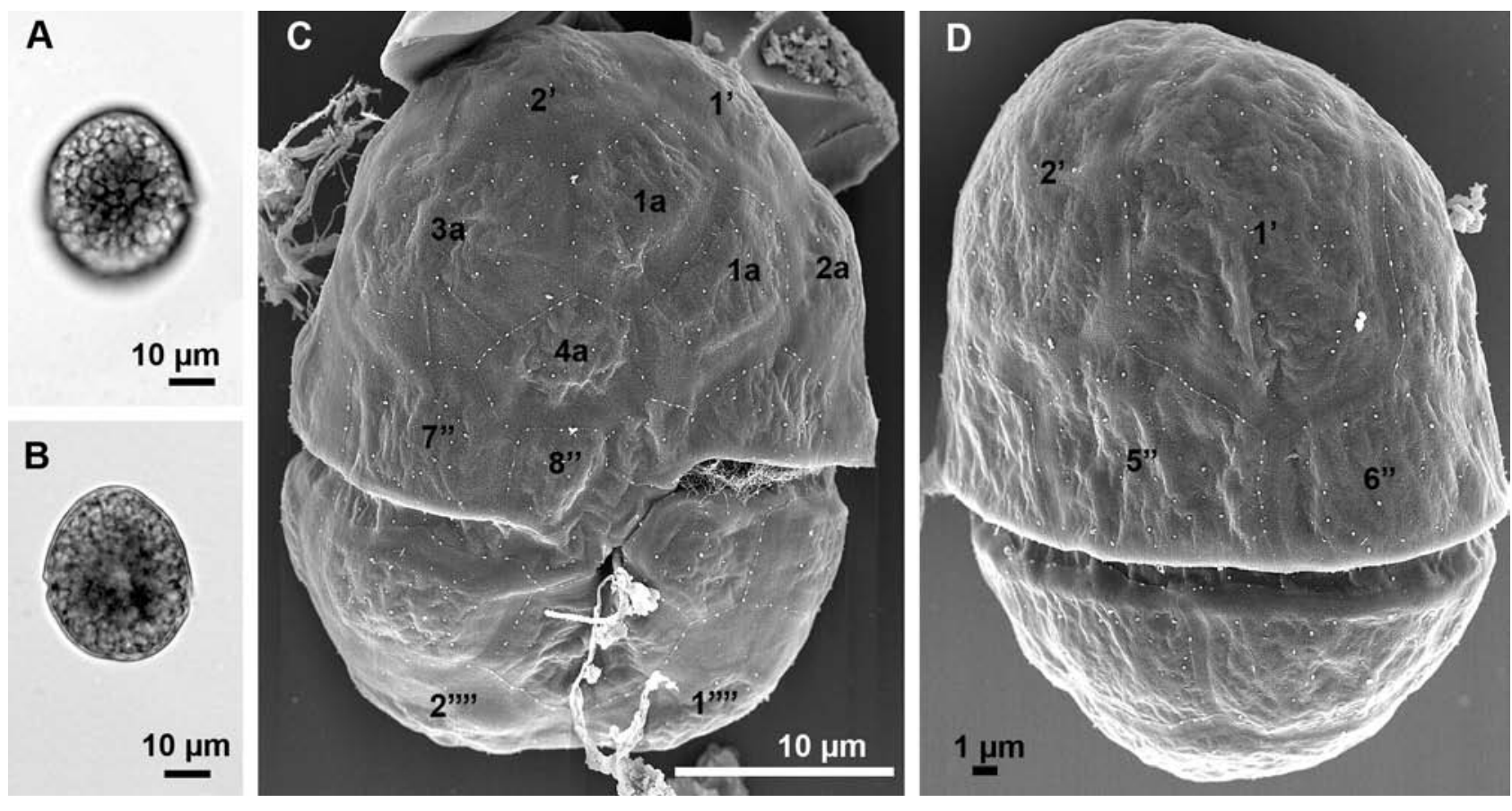

Figs 10A-D. Glenodiniopsis uliginosa. A, B. Live cells. C, D. SEM, ventral and dorsal views, respectively.

be: 2', 4a, 8", ?s, ?c, 7"', 2"'". The present material basically had a similar tabulation except for the 1a-plate, which was divided into two plates, very similar to the illustration of Popovský \& Pfiester (1990, fig. 151b). Length: ca. $40 \mu \mathrm{m}$, width: ca. $35 \mu \mathrm{m}$.

Distribution. Roncone (July).

Comments. This species is often referred to as $G$. steinii Woloszyńska (e.g. Popovský \& Pfiester 1990, Highfill \& Pfiester 1992), but Woloszyńska (1916) was unaware that Glenodinium uliginosum Schilling (1891) was a junior synonym of this species when she created the new genus Glenodiniopsis. The correct combination occurs in Lindemann (1928a), but he ascribed it to Woloszyńska rather than himself.

Highfill \& Pfiester (1992) made ultrastructural studies of this species and found that the numerous discoid chloroplasts seen in the light microscope represented one single multilobed chloroplast.

According to Höll (1928) this species prefers humus rich localities with low calcium contents $(4,8-25 \mathrm{mg} / \mathrm{L})$, e.g. peat bogs, and occurs only infrequently in areas with higher calcium levels. The geological substrate of Roncone is calcareous, calcium levels of the pond are about $47 \mathrm{mg} / \mathrm{L}$ (IASMA 1996-99). However this shallow pond is very turbid due to frequent resuspension of fine sediments.

\section{Family Peridiniaceae Ehrenberg}

Thecate cells with 5 postcingular and 2 antapical plates (e.g. Popovský \& Pfiester 1990).

\section{Genus Peridinium Ehrenberg}

Cells with plate formula: 4', 2-3a, 5-6c, 7", 5"', 2 "'. Chloroplasts are always present. Phylogenetic trees based on SSU rDNA, indicate that the genus as presently defined is polyphyletic (e.g. Saldarriaga et al. 2004).

\section{Subgenus Cleistoperidinium Lefèvre \\ Cells without an apical pore.}

\section{Peridinium apiculatum (Ehrenberg) Claparéde et Lachmann (Figs 11A-D).}

Cells are somewhat ovoid with an irregular margin. The cingulum is only slightly displaced (descending). The plate margins (sutures) are usually furnished with spiny flanges. A stigma could not be observed in the fixed material but has been observed on live material from Denmark (Gert Hansen, unpub. obs.). The plate tabulation is: 4', 2a, 7", 6c, ?s, 5"', 2"'” (Bourrelly 1970, as P. palatinum Lauterborn).

Length: 38-50 $\mu \mathrm{m}$, width: $32-44 \mu \mathrm{m}$.

Distribution. Canzolino (March), Lases (March), Madrano (March), Serraia (March), Terlago North (March), Terlago South (May, March).

Commments. This species is usually referred to as Peridinium palatinum Lauterborn (1896), but Lindemann (1928b) argued that it is identical to Glenodinium apiculatum Ehrenberg (1838) and made the 'new' combination Peridinium apiculatum (Ehrenberg) Lindemann, unaware that this combination 

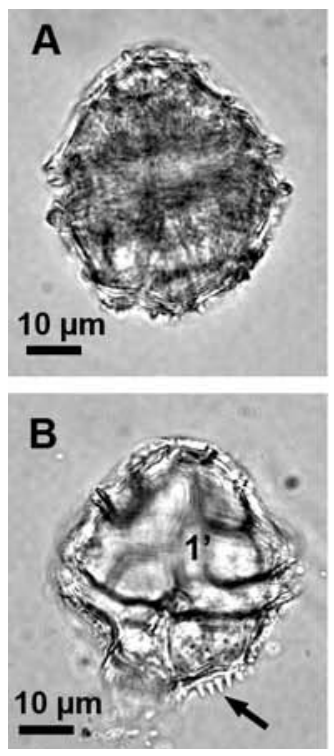
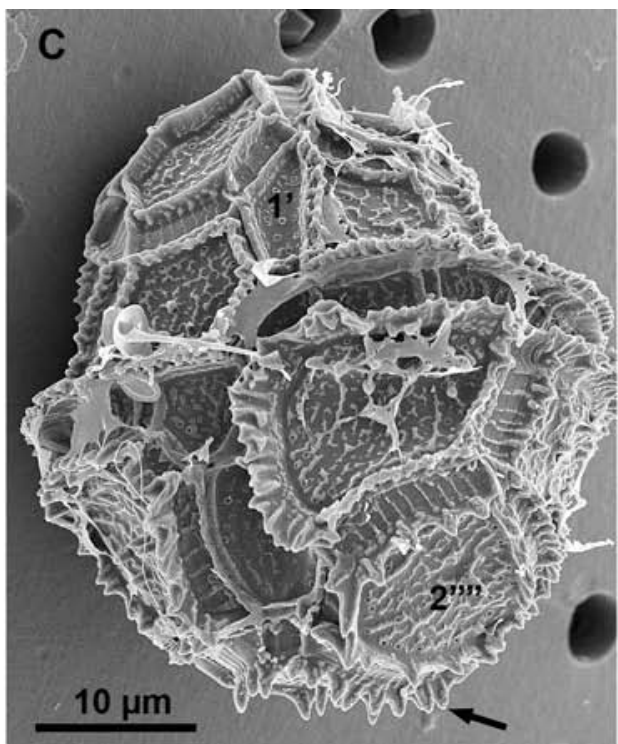

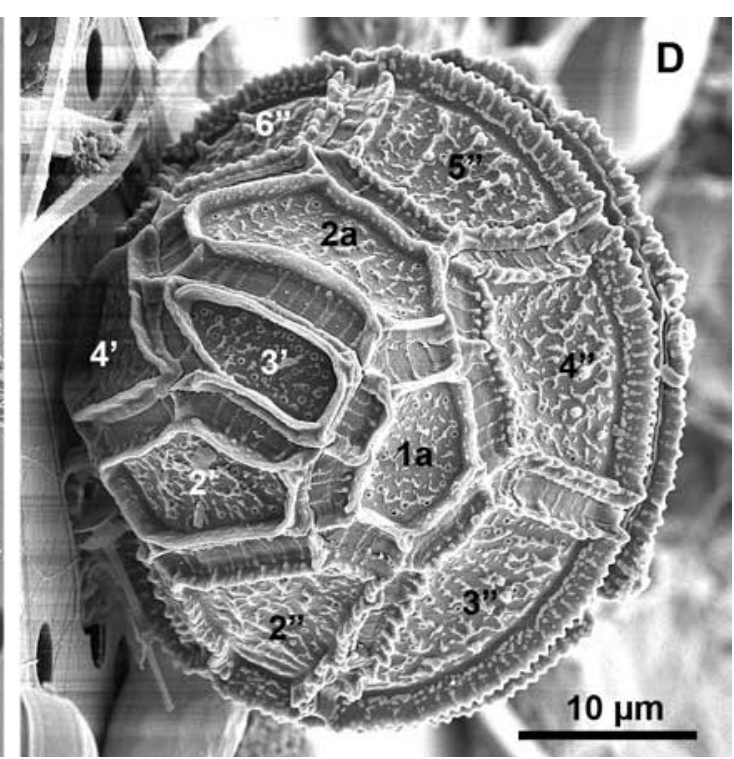

Figs 11A-D. Peridinium apiculatum. A, B. LM of fixed cells. C, D. SEM, ventral and apical views, respectively. Notice the spiny plate sutures (arrow).
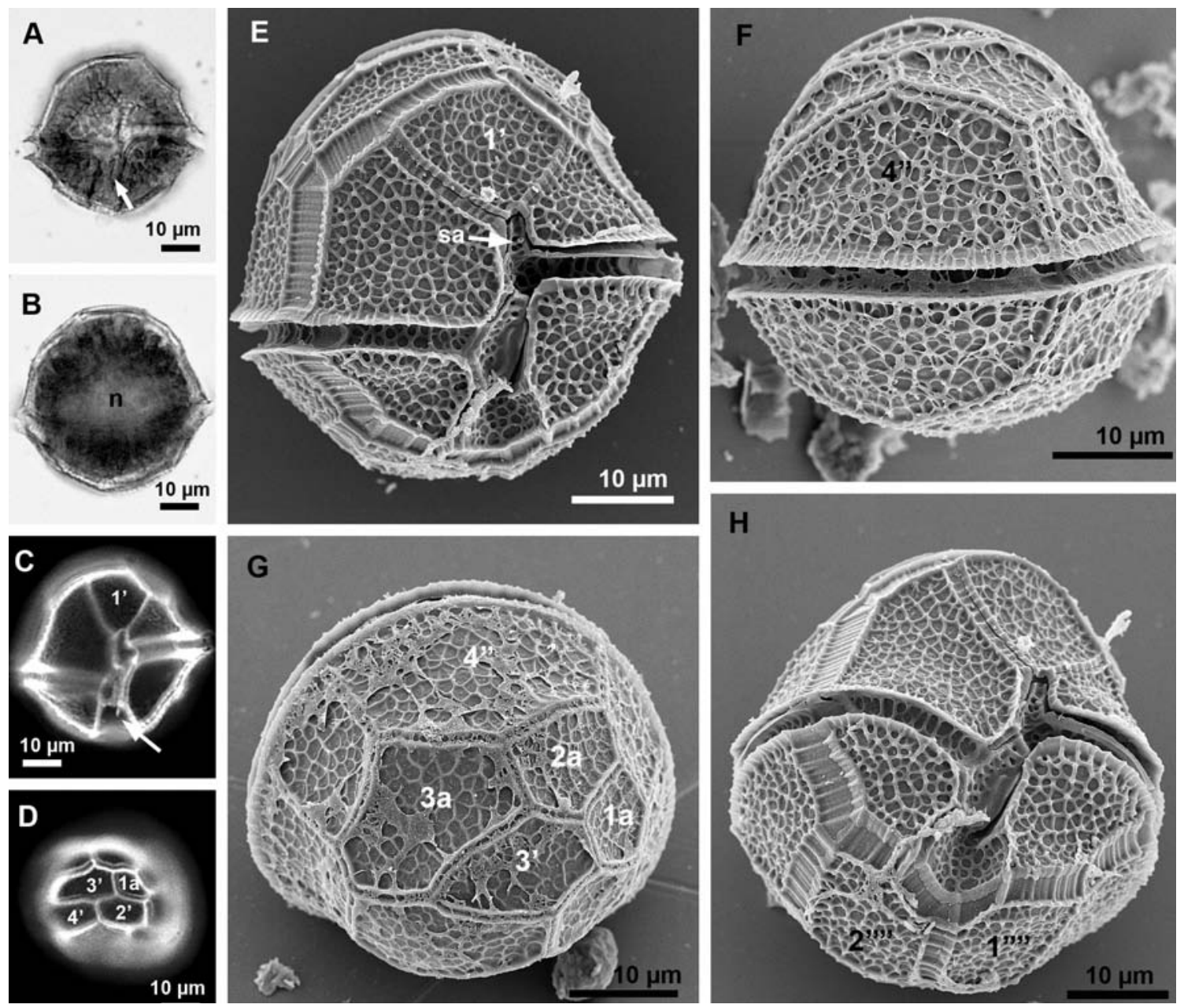

Figs 12A-H. Peridinium cinctum. A, B. LM of live cells; eyespot (arrow). C, D. Fluorescence microscopy of CalcoFluor White stained cells, revealing the plate pattern. Notice small spine on the sp-plate (arrow). E-H. SEM, E: ventral view, F: dorsal view, G: apical view, H: antapical-ventral view. 
had already been made by Claparède \& Lachmann (1859). Although, P. palatinum was generally accepted as a junior synonym of $P$. apiculatum in earlier literature (e.g. Höll 1928, Woloszyńska 1952), the name P. palatinum for unknown reasons has become common usage in later literature (e.g. Popovský \& Pfiester 1990). Höll (1928) considers $P$. apiculatum a coldwater species; our findings also suggest that this species is an early spring species, and it seems to be restricted to meso-eutrophic lakes.

\section{Peridinium cintum (O.F. Müller) Ehrenberg (Figs 12A-H).}

Cells are ovoid with a somewhat angular circumference. The episome is larger than the hyposome. The 1'plate is relative large and almost isohedrical or slightly longer than wide. Plate 3' has a characteristic pointed shape and plate 4 ' is large and bordered at its anterior by plate $2 \mathrm{a}$ and $3 \mathrm{a}$. The sa-plate is narrow and extends slightly onto the episome, i.e. is bordered by plate 1". The anterior left part of the posterior sulcal plate (sp) is usually furnished with a thickening that can develop into a small spine. The thecal plates are reticulated. Plate formula: 4', 3a, 7", 5c, ?s, 5"', 2"”. The cell contains numerous brownish chloroplasts and a narrow red stigma within the sulcus. The nucleus is located centrally in the cell. Length: $44-59 \mu \mathrm{m}$, width: $47-58 \mu \mathrm{m}$.

Distribution. Caldonazzo (July), Lases (March, July), Lavarone (April, July), Ledro (July), Malghette (July), Molveno (July), Tenno (July), Terlago South (May), Tovel (July).

Comments. This species was widely distributed in summer and was found in oligotrophic to eutrophic lakes or ponds in the littoral zone. It also appears to have a broad pH tolerance (Höll 1928). It can be distinguished from $P$. volzii (see below) by its more irregular cell shape and different shapes of plates 3' and 4".

\section{Peridinium gatunense Nygaard (Figs 13A-D).}

Cells are spherical and the epi- and hyposome are equal in size. The cingulum is deep and displaced about one cingular width. The first apical plate (1') is small, 4-
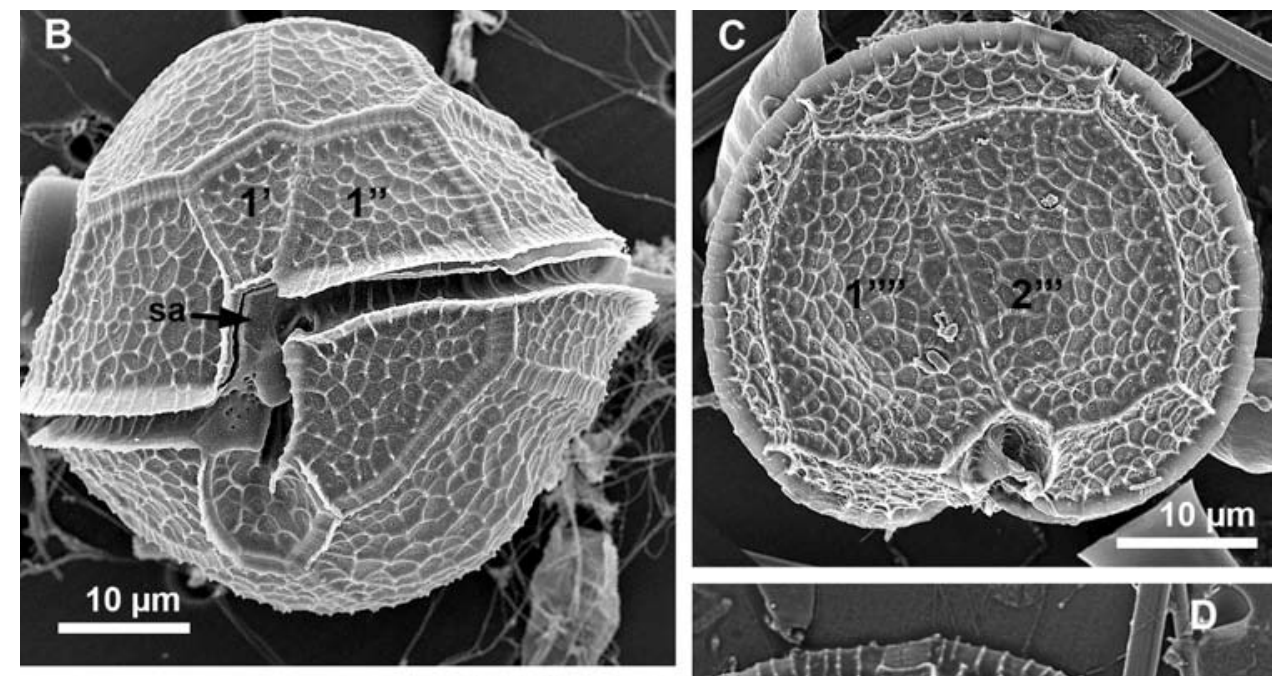

\section{A}

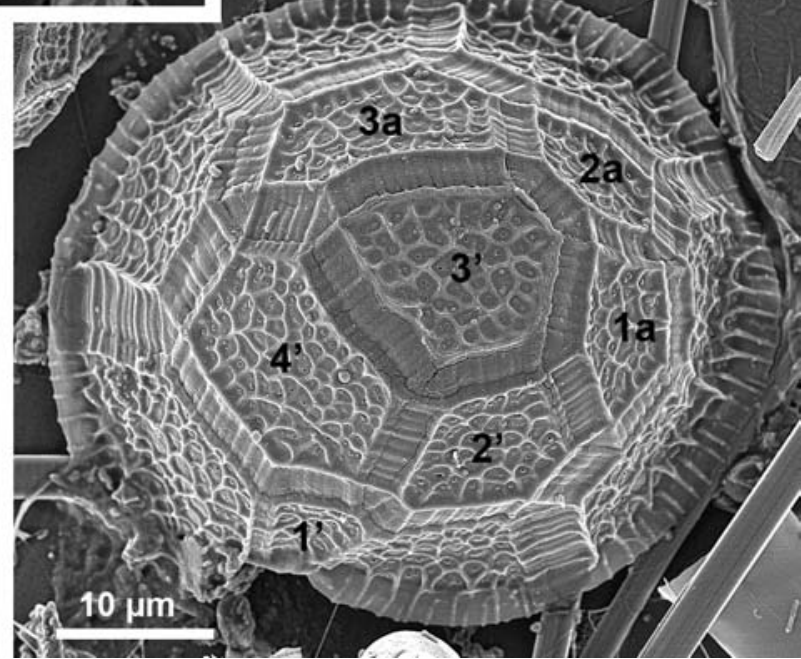

Figs 13 A-D. Peridinium gatunense. A. Live cell. B-D. SEM, B: ventral view, C: antapical view, D: apical view. 
sided and somewhat asymmetrical. Thecal plates are reticulated. The sa-plate is narrow and is not bordered by plate 1". Plate formula: 4', 3a, 7", 5c, ?s, 5"', 2"'”. The cell contains numerous small chloroplasts and the nucleus is situated in the central part of the cell. Length: 36-50 $\mu \mathrm{m}$, width: $40-47 \mu \mathrm{m}$.

Distribution. Terlago North (May, July, August), Terlago South (May, July). It was significantly more abundant in the northern basin.

Comments. This species may be found in warm mesotrophic waters and its yearly blooming in Lake Kinneret is well known (e.g. Pollingher 1987, as P. cinctum $\mathrm{f}$. westii). Its growth characteristics have been studied in details by Lindström $(1984,1991)$ and Alster et al . (2006). Highest growth rates were obtained at relatively high conductivity, $\mathrm{pH} 7-8$ and a temperature about 23 ${ }^{\circ} \mathrm{C}$. In addition a supplement of selenium was required. This dinoflagellate was found only in Terlago Lake. Significantly, this is the Trentino lake with the highest mineral content (conductivity $>450 \mu \mathrm{S} \mathrm{cm}^{-1}$ ).

\section{Peridinium volzii Lemmermann (Figs 14A-D).}

Cells are ovoid and slightly dorso-ventrally flattened. The cingulum is median or submedian and slightly displaced. Plate 1' is small and rhomboid to slightly elongate. The sulcus is narrow and the sa-plate extends onto the episome. Plate 4" is large, rectangular and is only bordered by plate $2 \mathrm{a}$ at its anterior margin. The thecal plates are reticulated. Plate formula: 4', 3a, 7", 5c, ?s, 5"', 2"'. The cell contains brownish chloroplasts and an elongated red stigma within the sulcus. Length: 33-43 $\mu \mathrm{m}$, width: 30-40 $\mu \mathrm{m}$.
Distribution. Colbricon (July), Roncone (July), Santo (August), Serraia (June), Terlago North (May, July).

Comments. Popovský and Pfiester (1990) considered $P$. volzii as a junior synonym of $P$. willei, but it can be distinguished from $P$. willei (see below) by its different cell shape, the considerably smaller 1'-plate and the extension of the sa-plate onto the episome. Furthermore, it also appears that ecological differences separate these two species. Thus, $P$. volzii seems to have more narrow limits with respect to seasonal occurrence and $\mathrm{pH}$. For example $P$. willei was found in Denmark at $\mathrm{pH} 4.2-8.5$, whereas $P$. volzii was confined to lakes with a slightly basic pH (Olrik 1992). However, these ecological differences were not apparent in the present study, where both species occurred in a broad range of lakes with respect to conductivity and trophy classes. However, this dinoflagellate was more common in eutrophic lakes and its distribution was limited to late-spring/summer.

\section{Peridinium volzii f. meandricum Lauterborn (Figs 15A-G).}

This form is distinguished from the typical $P$. volzii by the presence of raised plate margins and the distinctive ornamentation of the thecal plates consisting of 'worm-like' elevations or ridges. Length $40-45 \mu \mathrm{m}$; width $40-45 \mu \mathrm{m}$.

Distribution. Lavarone (July, August).

Comments. This form has primarily been found in the Alps (e.g. Lindemann 1925), but it has also been reported from Australia (Huber-Pestalozzi 1968) and has also been observed in Lac St. Croix, an artificial high altitude lake in Alpes de Provence (G. Hansen,
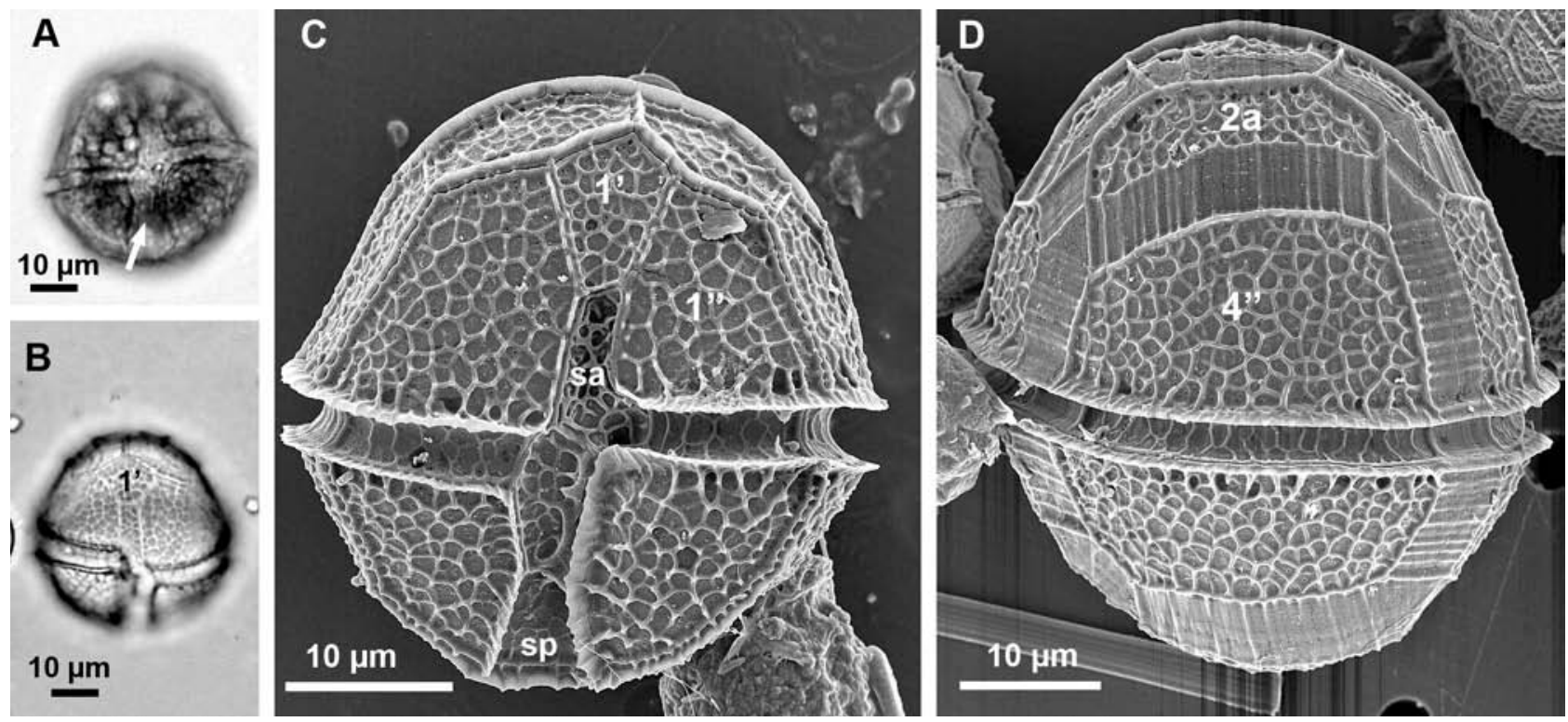

Figs 14A-D. Peridinium volzii. A. Live cell, eyespot (arrow). B. Empty theca. C, D. SEM, A: ventral view, B: dorsal view. 
A

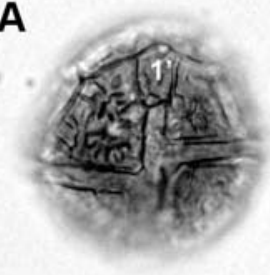

C
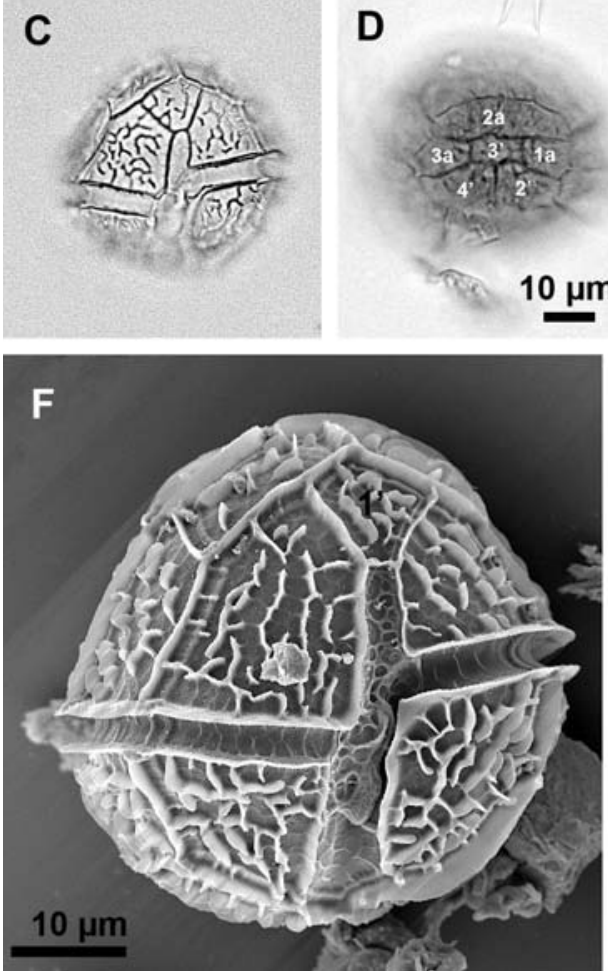

B

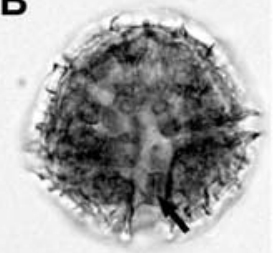

D

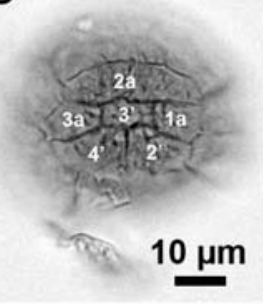

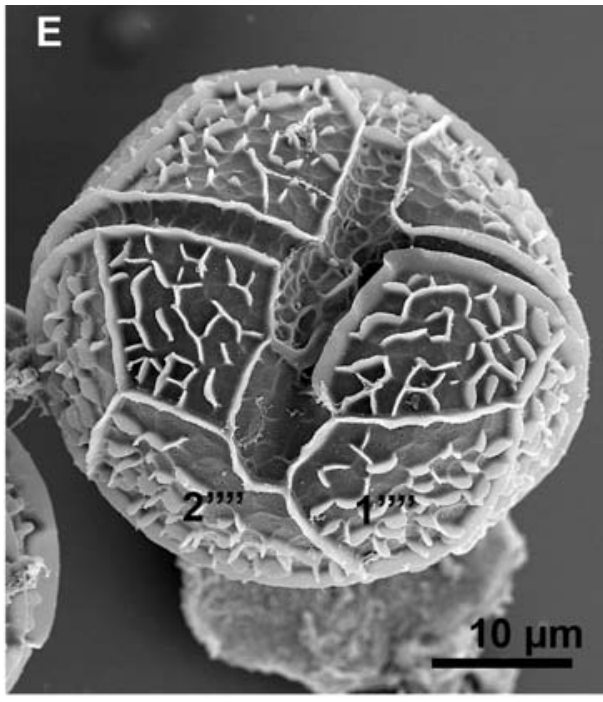

G

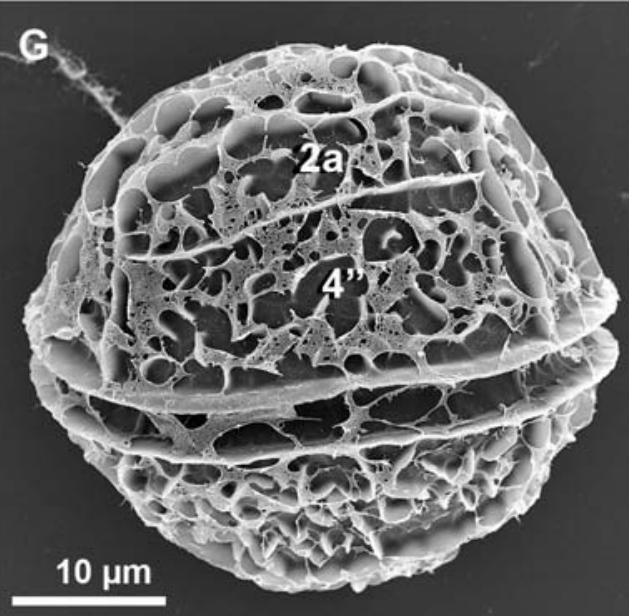

Figs 15A-G. Peridinium volzii f. meandricum. A, B. Live cells, eyespot (arrow). C, D. Empty thecae, ventral and apical view, respectively. E-G. SEM, E: antapical-ventral view F: ventral view, G: dorsal view.
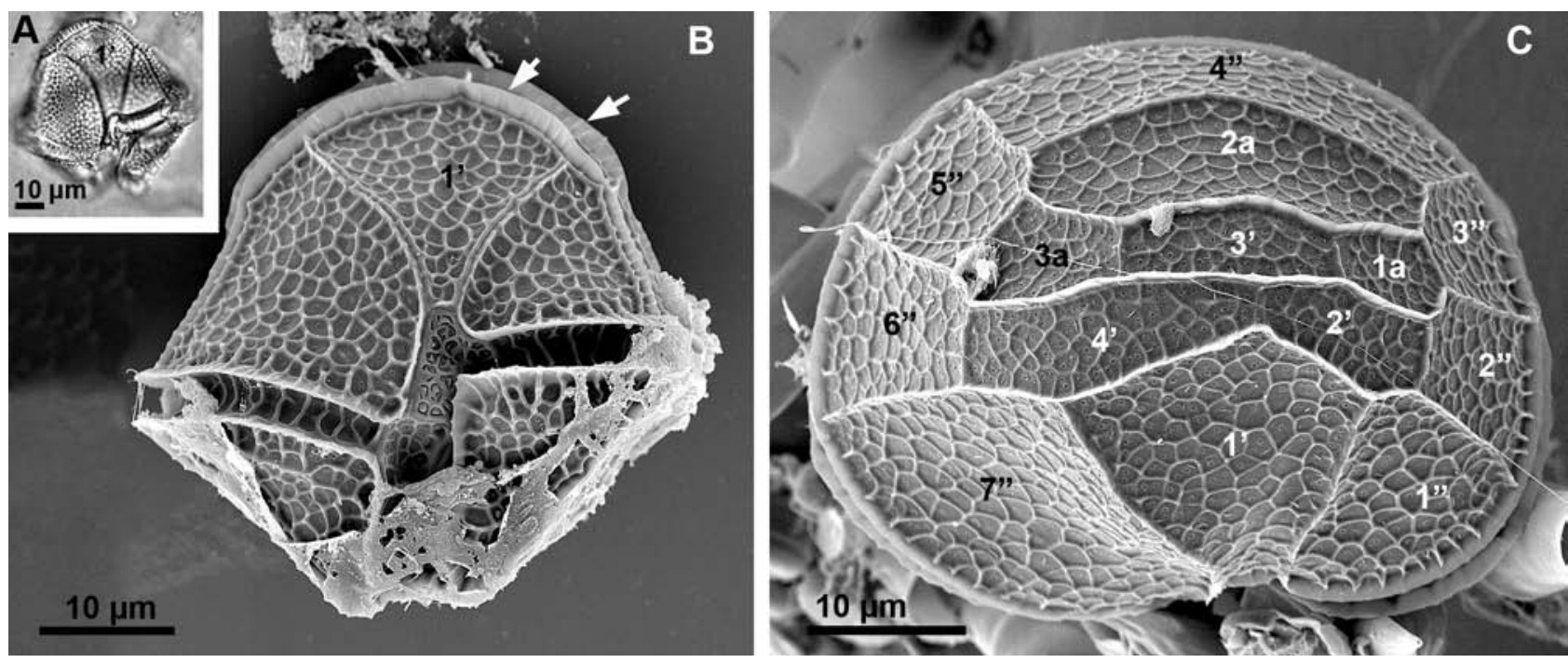

Figs 16A-C. Peridinium willei. A. LM of empty theca. B, C. SEM, ventral and apical view respectively. Notice wing-like extensions (arrows). 
unpubl. obs.). The very distinctive ornamentation is maintained in culture, indicating that it is a stable character (G. Hansen, unpubl.), but the LSU rDNA sequences of $P$. volzii and $P$. volzii f. meandricum are similar (Niels Daugbjerg, pers. com.).

\section{Peridinium willei Huitfeldt-Kaas (Figs 16A-C).}

The episome is hemispherical and slightly larger than the hyposome, which is somewhat conical. The submedian cingulum is displaced one cingular width. Plate 1' is rather large and wide. The sulcus is narrow. The thecal plates are reticulated. The epithecal plate borders often have wing-like extensions. The right and left sulcal borders also have well developed lists. Plate formula: 4', 3a, 7", 5c, ?s, 5"', 2"'”. Length: 42-63 $\mu \mathrm{m}$, width: $42-59 \mu \mathrm{m}$.

Distribution. Ampola (July), Caldonazzo (March, May, July), Lases (July), Rane (July), Serraia (July), Tovel (June).

Comments. According to Höll (1928), this species has a very broad distribution (see also comments on $P$. volzii); our survey also confirmed its wide distribution among lake types although it seemed to be restricted to spring/summer.

Subgenus Poroperidinium Lefèvre

Cells with an apical pore

\section{Peridinium aciculiferum Lemmermann (Figs 17A-C).}

The cell has a conical episome and a broadly rounded hyposome with tiny antapical spines. The cingulum is median and not displaced. The thecal plates are smooth and penetrated by numerous pores. The 2a-plate is 5 -sided and asymmetric. The plate tabulation is: Po, $\mathrm{x}, 4$ ', 3a, 7', $6 c, ? \mathrm{~s}, 5$ "', 2"'. Length: 36-40 $\mu \mathrm{m}$, width: $28-30 \mu \mathrm{m}$.

Distribution. Tovel (January, April), Canzolino (March), Lases (March), Lavarone (April), Serraia (March), Terlago North (March), Terlago South (March).

Comments. Peridinium aciculiferum is a cold water species, and seems to prefer hard water lakes. It may produce a toxic substance(s) that may function as an allelochemical (Rengefors \& Legrand 2001). In Lake Tovel it has occasionally produced winter blooms with discolouration of ice. Interestingly, molecular data have shown that $P$. aciculiferum and Scrippsiella hangoei (Schiller) Larsen, a brackish water species from the Baltic are similar with respect to SSU and LSU rDNA sequences (Logares et al. 2007).

\section{Peridinium centenniale (Playfair) Lefévre (Figs 18A-D).}

Cells are ovoid in shape and have a markedly larger epi- than hyposome. The nucleus is situated posteriorly and a spherical inclusion body may be situated anteriorly. The thecal plates are furnished with numerous scattered pores with an elevated rim, and also tiny knobs that generally are arranged in a single row along the plate margins. The sa-plate is relatively large and skewed towards the right. Plate formula Po, x, 4', 2a, 7', 6c, ?s, 5", 2"'. Length: 36-42 $\mu \mathrm{m}$, width: 28-34 $\mu \mathrm{m}$.

Distribution. Rane (July).
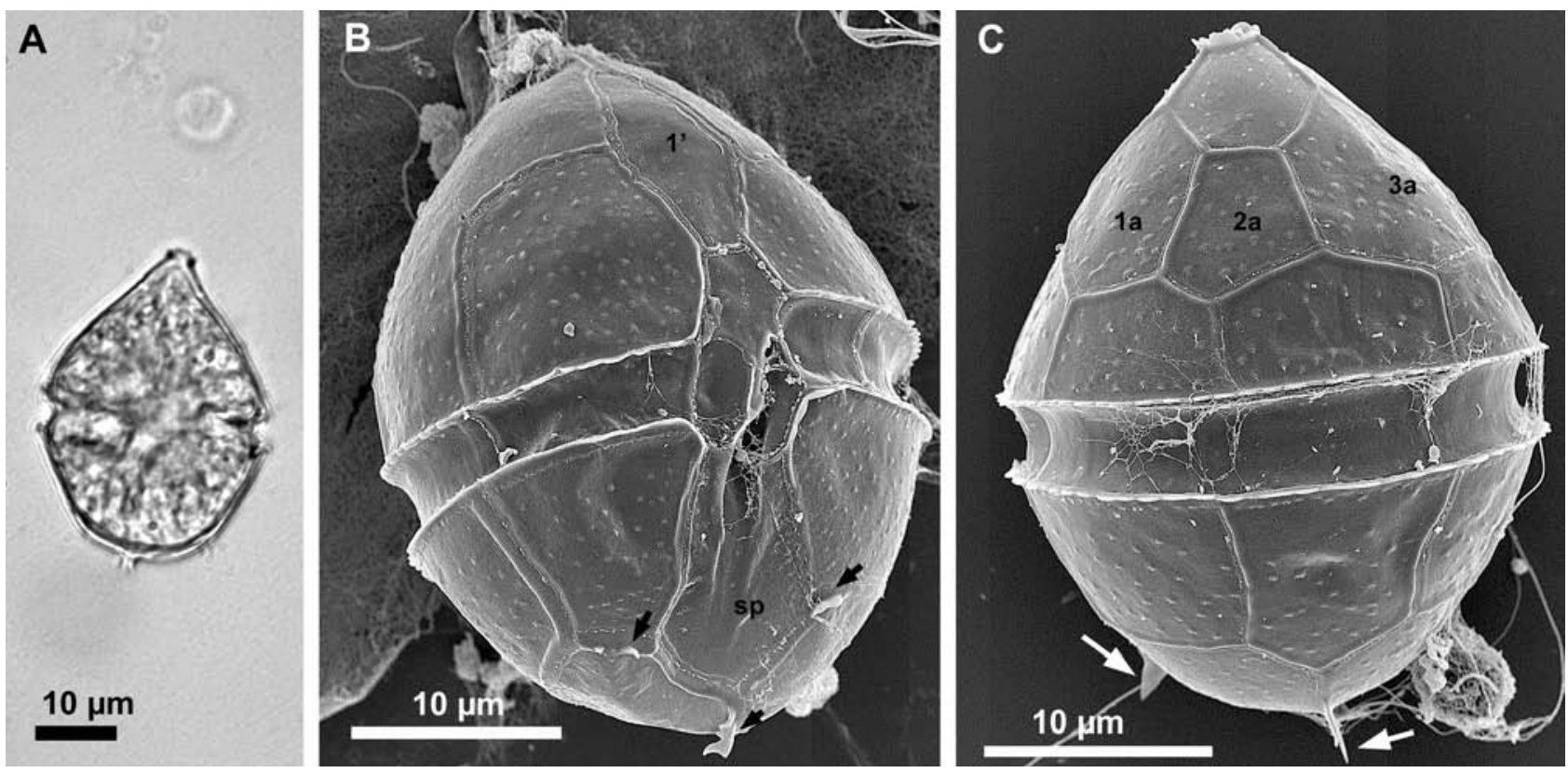

Figs 17A-C. Peridinium aciculiferum. A. LM of fixed cell. B, C. SEM, ventral and dorsal views, respectively. Antapical spines are marked by arrows. 


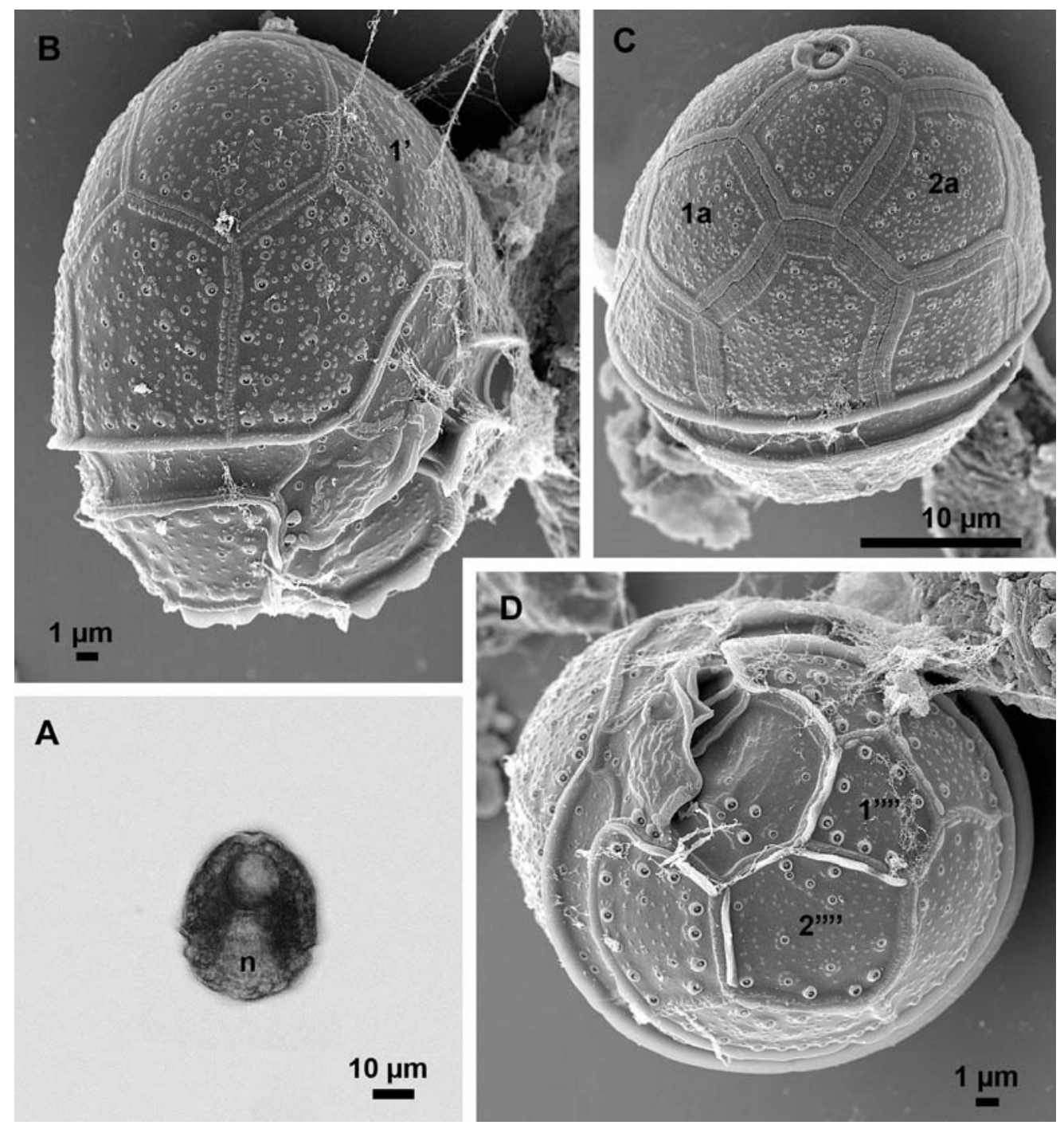

Figs 18A-D. Peridinium centenniale. A. Live cell. B-D. SEM, B: right ventral view, C: apical-dorsal view, E: antapical view.

Comments. Sometimes this species is considered a variety of $P$. umbonatum Stein, e.g. Popovský \& Pfiester (1990), however, its particular shape, sulcal arrangement and distinct thecal ornamentation justify it as a separate species. This dinoflagellate was only found in acidic Rane Pond.

\section{Peridinium goslavienses Woloszyńska (Figs 19A-F).}

Cells with conical and hemispherical epi- and hyposome, respectively. Cingulum is slightly submedian and not displaced. The thecal plates are smooth and furnished with pores with a small rim. The pores are scattered, though with a tendency for a distribution along the plate borders. The 1' plate has relatively long posterior margins, consequently the plates 1"- and 7" are also quite long. Plate 4" is also relatively long. Plate 1" "' is furnished with a prominent spine curving to the right. Plate formula: Po, x, 4', 2a, 7", 6c, ?s, 5"', 2"'.
Numerous chloroplasts are present. Length: ca. $30 \mu \mathrm{m}$, width: ca. $25 \mu \mathrm{m}$.

Distribution. Colbricon (July), Lavarone (July).

Comments. Popovskỳ \& Pfiester (1990) considered this species as a variety of Peridinium umbonatum. However, the different shape of the cell, the smooth thecal plates and the prominent right curving antapical spine, as opposed to $P$. umbonatum, justify it as a separate species. In Woloszyńska's (1916) original description there was uncertainty about the presence of chloroplasts, but these were consistently present in our material.

\section{Peridinium inconspicuum Lemmermann (Figs 20A-J).}

Small cells with a slightly larger epi- than hyposome. The latter is somewhat angular while the episome is ovoid or conical. The submedian cingulum is not or only slightly displaced. The ornamentation of the thecal plates is quite 

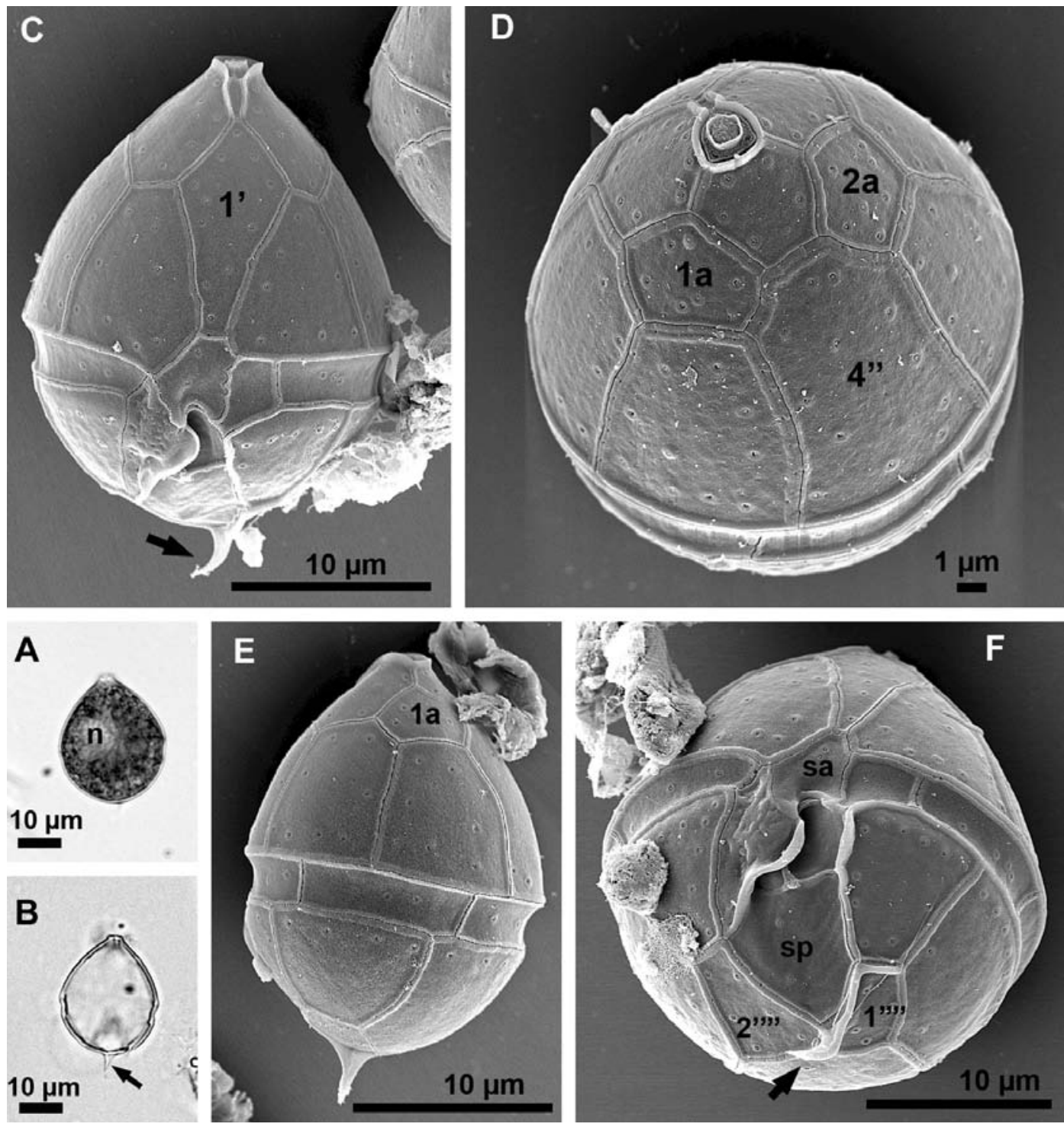

Figs 19A-F. Peridinium goslaviense. A. Live cell. B. Empty theca, antapical spine (arrow). C-F. SEM, C: ventral view, D: apical-dorsal view, E: Left-lateral view, F: antapical view, antapical spine (arrow).

variable, from relatively smooth to reticulated, and antapical spines are often present. Plate formula: Po, x, 4', 2a, 7", $6 \mathrm{c}, ? \mathrm{~s}, 5$ "', 2"'. Length: 15-25 $\mu \mathrm{m}$, width: $22-15 \mu \mathrm{m}$.

Distribution. Ampola (July), Caldonazzo (July), Canzolino (May, July), Columba (July), Lagorai (July), Lases (July), Lavarone (April, July, August), Levico (July), Madrano (March), Malghette (July), Piazze (July), Roncone (July), Santo (March, July, August), Serraia (March, April, May, June, July), Stellune (July), Terlago Nord (May, August), Terlago South (May, July), Tovel (June, July, August), Valle (July).

Comments. This species is very similar to and considered as conspecific with $P$. umbonatum Stein by Popovský \& Pfiester (1990). However, molecular data suggest these are separate species (Yoshito Takano, Univ. of Hokkaido, pers. com.). P. inconspicuum was originally described by Lemmermann (1900a) without any illustrations, but according to the diagnosis the cell is about $15 \mu \mathrm{m}$ in length and $12 \mu \mathrm{m}$ in width. The hyposome is truncated, somewhat concave ('ausgerandet') and furnished with two short spines. Later, Lemmermann (1910) provided illustrations, and it became apparent that $P$. inconspicuum and $P$. umbonatum are very similar. According to Lemmermann (1910) the two species are distinguished by the presence of 3 antapical spines in $P$. inconspicuum. However, this appears to be a very variable character of this species. In the present study $P$. inconspicuum is distinguished from $P$. umbonatum by its smaller size and angular hyposome often with spines. 

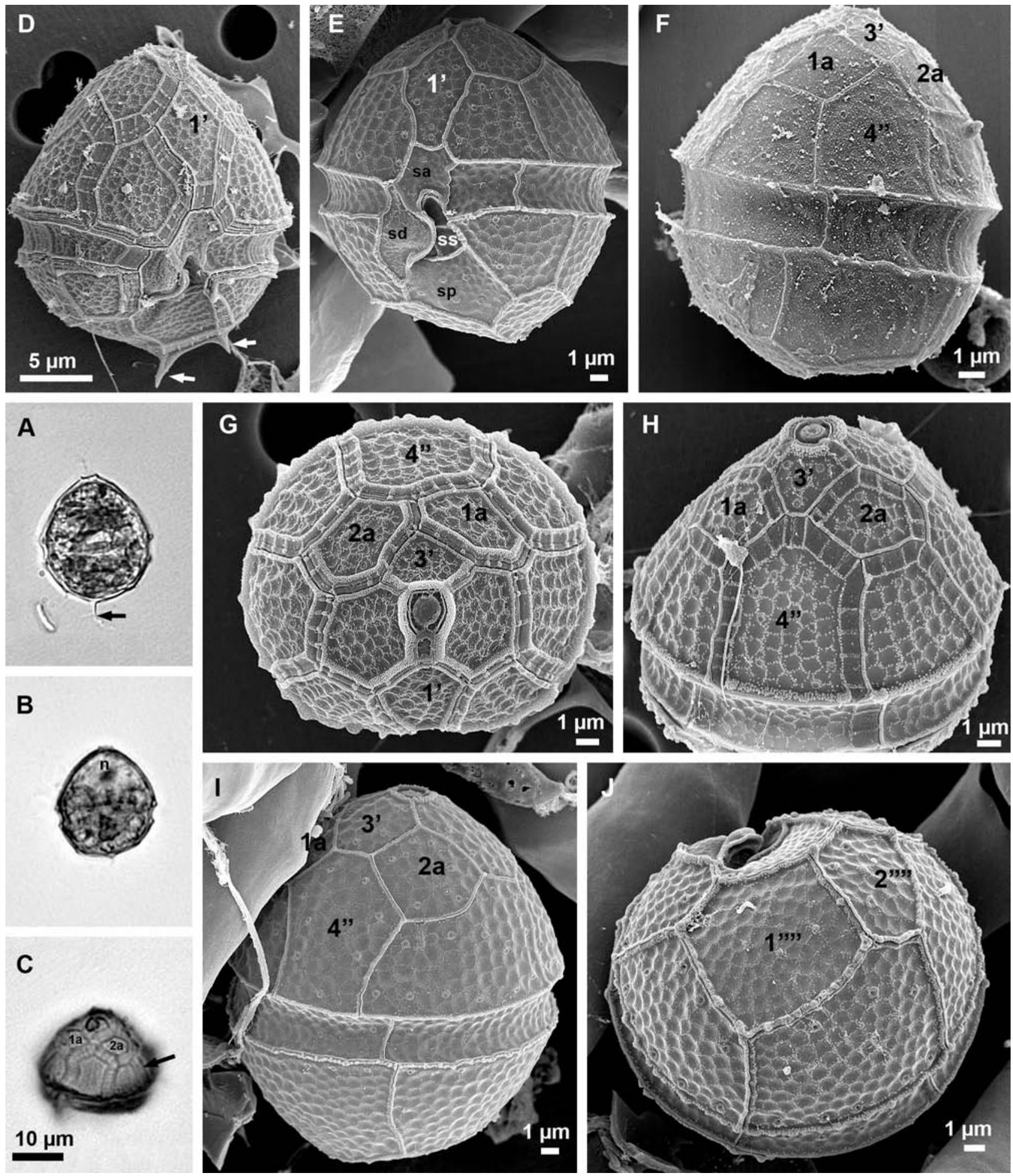

Figs 20A-J. Peridinium inconspicuum. A, B. Live cells, antapical spine (arrow). C. Empty theca. Notice broad intercalary bands (arrow). D-J. SEM, D: specimen with antapical spines, E: specimen without antapical spines and a more smooth theca, F: contactum type, G: remotum type, H, I: conjunctum type, J: antapical view. 
Plate 3' and 4" can occur in three different configurations: tab. contactum, i.e. the two plates border each other in one point (Fig. 20C, F), tab. remotum, i.e. the two plates are separated (Fig. 20G) or tab. conjunctum, i.e. the two plates are bordered by a suture (Fig. 20H, I) (Lefèvre 1932). Usually only one type dominates at a particular locality, but both remotum and conjunctum occurred simultaneously in L. Lases. Variability of this feature has also been shown in clonal cultures of $P$. umbonatum (Elbrächter \& Meyer 2001). According to Höll (1928) this species is restricted to high alkalinity lakes, but in the present study it was the most widespread species and also found in lakes with low conductivity (Table 1).

\section{Genus Peridiniopsis Lemmermann}

Cells with plate formula: 3-5', 0-1a (2a), 6-7" (8"), 5"', 2"'" (Bourrelly 1968). Chloroplasts present or absent.

\section{Peridiniopsis berolinensis (Lemmermann) Bourrelly (Figs 21A-E).}

Cells are ovoid and the epi- and hyposome are hemispherical. The latter is often furnished with one or two antapical spines. The cingulum is median or submedian and only slightly displaced. The thecal plates are smooth but minute spines are usually present along the borders of the hyposomal plates. Cells are colourless but an orange body, most likely a food vacuole, is usually present in the episome. Plate formula: Po, x, 4', 6", 6c, 6s, 5'”, 2"', (Fukuyo et al. 1990). Length: $30 \mu \mathrm{m}$, width: $30 \mu \mathrm{m}$.

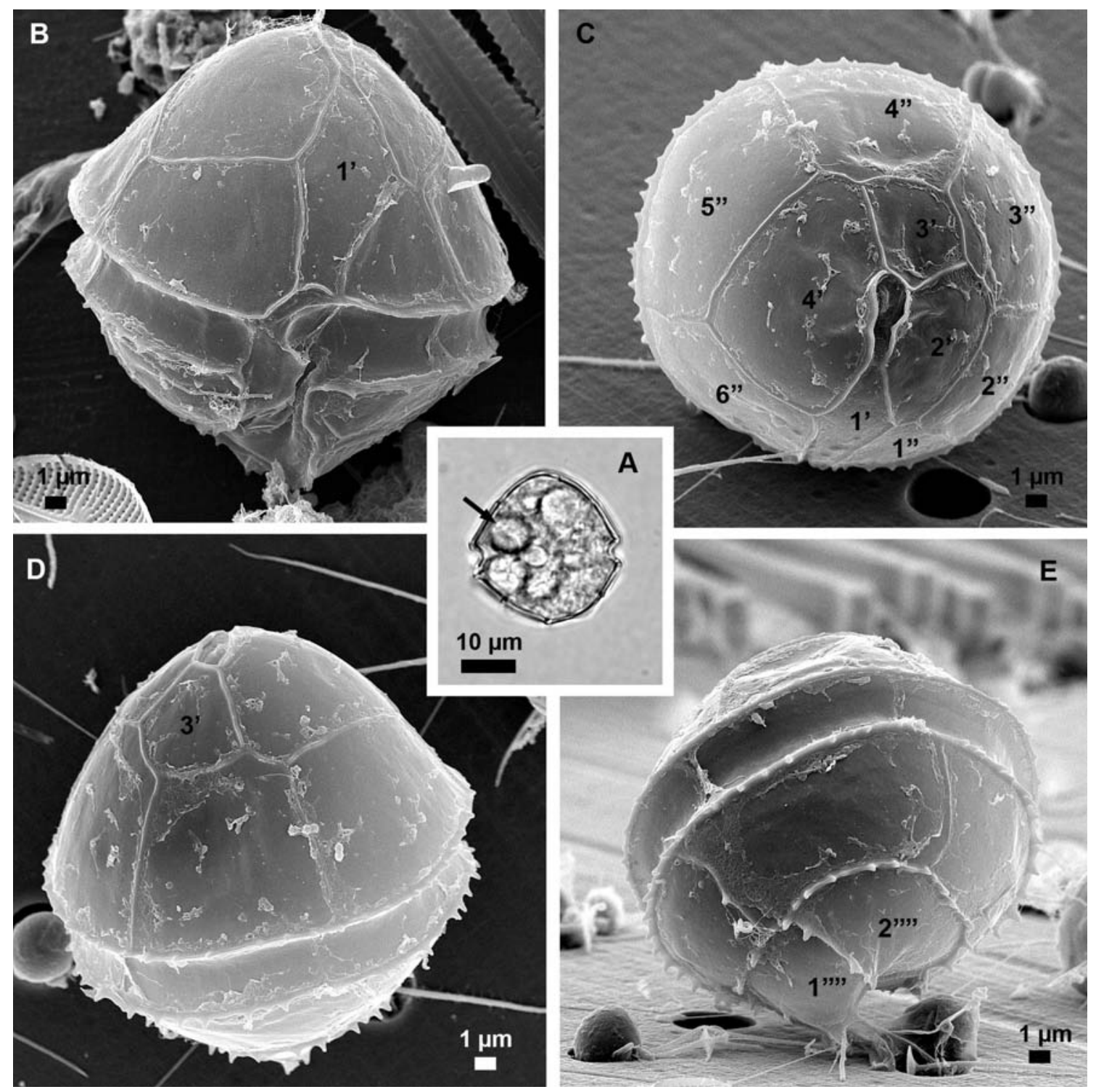

Figs 21A-E. Peridiniopsis berolinensis. A. Live cell. The orange inclusion body is marked by an arrow. B-E. SEM, B: ventral view, C: apical view, D: dorsal view, E: antapical view. 
Distribution. Columba, Lases, Lavarone, Serraia all in July.

Commments. The feeding behaviour of this heterotrophic dinoflagellate has been studied in detail (Calado \& Moestrup 1997). Feeding involves a peduncle (feeding tube), and it seems to be rather unselective with respect to prey items, which can be various chlorophytes, dinoflagellates, diatoms, Fungi Imperfecti and even injured nematodes. In some floras it is described as having chloroplasts (e.g. Huber-Pestalozzi 1968), which most likely represent food remnants or kleptochloroplasts.

\section{Peridiniopsis cunningtonii Lemmermann (Figs 22A-G).}

The cell is more or less ovoid and slightly dorso-ventrally flattened. The episome is conical, the hyposome rounded or somewhat angular. The cingulum is submedian, i.e. the episome is longer than the hyposome, and not displaced. The yellowish brown chloroplast(s) are arranged in a somewhat radiating pattern. A distinct red eyespot is present within the sulcus. The nucleus is situated in the hyposome. The thecal plates are reticulated and usually furnished with small spines. This is particularly evident along the borders of the hyposomal plates. In addition 4-6 prominent spines are always present on the hyposomal plates. Plate formula: Po, x, 4', 1a, 6", 6c, 5s, 5"', 2" (Fukuyo et al. 1990). Aberrant specimens with up to 3 anterior intercalary plates were occasionally observed (Fig. 22E). Length: 25-36 $\mu \mathrm{m}$, width 22-30 $\mu \mathrm{m}$.

Distribution. Caldonazzo (July), Canzolino (July), Columba (July), Lases (July), Levico, (July), Piazze (July), Roncone (July), Serraia (July, August), Santo (July, August), Terlago North (July, August), Terlago South (July).

Commments. P. cunningtonii is somewhat similar to P. quadridens (Stein) Bourrelly but this species has a different plate formula; Po, x, 5', 1a, 7", 6c, 5s, 5"', 2"', and never more than 4 antapical spines (Carty 1989). Also $P$. quadridens is apparently a coldwater species (Höll 1928), but P. cunningtonii only occurred in JulyAugust samples suggesting it is a warm water species. In this study, its presence was limited to meso-eutrophic lakes (Table 1).

\section{Peridiniopsis elpatiewskyi (Ostenfeld) Bourrelly} (Figs 23A-E).

Cells are ovoid, but both the epi- and hyposome have a somewhat angular appearance. The cingulum is slightly submedian and not displaced. The thecal plates are reticulated and furnished with numerous scattered pores. Often the surface reticulations form characteristic longitudinal striae. The hyposomal plates have numerous distinct spines along their borders. Plate formula: Po, x, 4', 7", 6c, 5s, 5"', 2"' (Fukuyo et al. 1990). The sp-plate is relative large oblique and displaced to the left. The 1'- plate is relatively narrow. Length: $34-36 \mu \mathrm{m}$, width: $30-$ $34 \mu \mathrm{m}$.

Distribution. Canzolino (July), Lases (July), Levico (July), Santo (August), Serraia (July, August), Terlago Nord (May, July), Tovel (July).

Comments. P. elpatiewskyi may be confused with $P$. cunningtonii as this species may also have spines along the plate margins and a similar sp-plate. However, $P$. cunningtonii is distinguished by the presence of 4-6 prominent spines in the centre of the hypothecal plates. In addition, it differs by the presence of 6 precingular plates and a 1a-plate. Meyer \& Elbrächter (1996) pointed out that Peridinium umbonatum var. elpatiewskyi Ostenfeld and P. marchicum var. simplex Woloszyńska considered as conspecific by Lindemann (1919) differ in plate tabulation and represent two different species, but the latter name has since become the common usage for Peridiniopsis elpatiewskyi. But rather than changing the name on this very common taxon, Meyer \& Elbrächter proposed to conserve the name, which has subsequently been done according to the rules of the ICBN.

According to Höll (1928) this species requires a relatively high $\mathrm{pH}$ and seems to be absent from humus rich habitats. In this study it was found in lakes with neutral to alkaline $\mathrm{pH}$, and occurred only during summer, suggesting it is a warm water species.

\section{Peridiniopsis kevei Grigorszky et Vasas (Figs 24A-C).}

The cell has a very characteristic biconical or rhomboid shape that is further accentuated by the distinct antapical spine on the 1"'"-plate. The hyposomal plates are furnished with minute spines along their borders. The cingulum is median, deep and only slightly displaced. The sulcus is narrow, deep and somewhat curved. The 1' plate has almost parallel sides and a somewhat irregular shape. The 1a-plate is rhomboid in shape. The cell contains numerous parietal yellowish chloroplasts. A distinct eyespot is present within the sulcus. Plate formula: Po, x, 3', 1a, 6", 5c, ?s, 5"', 2'”, (Grigorszky 1999). Length: 33-42 $\mu \mathrm{m}$ (ex. spine), width $30-38 \mu \mathrm{m}$.

Distribution. Terlago North (May), Terlago South (May, July), Caldonazzo (May).

Comments. There is some confusion about the correct epithet of this species. Leitao et al. (2001) described an identical species from River Loire and associated streams present in concentrations enough to discolour the water as $P$. corillionii Leitao, Ten-Hage, Mascarell et Couté. Grigorszky et al. (2001) made similar observations for a species collected from several European lakes and rivers, including L.Garda and the River Po. They described it as P. kevei Grigorszky et Vasas, at the same time pointing out that the species had previously been 

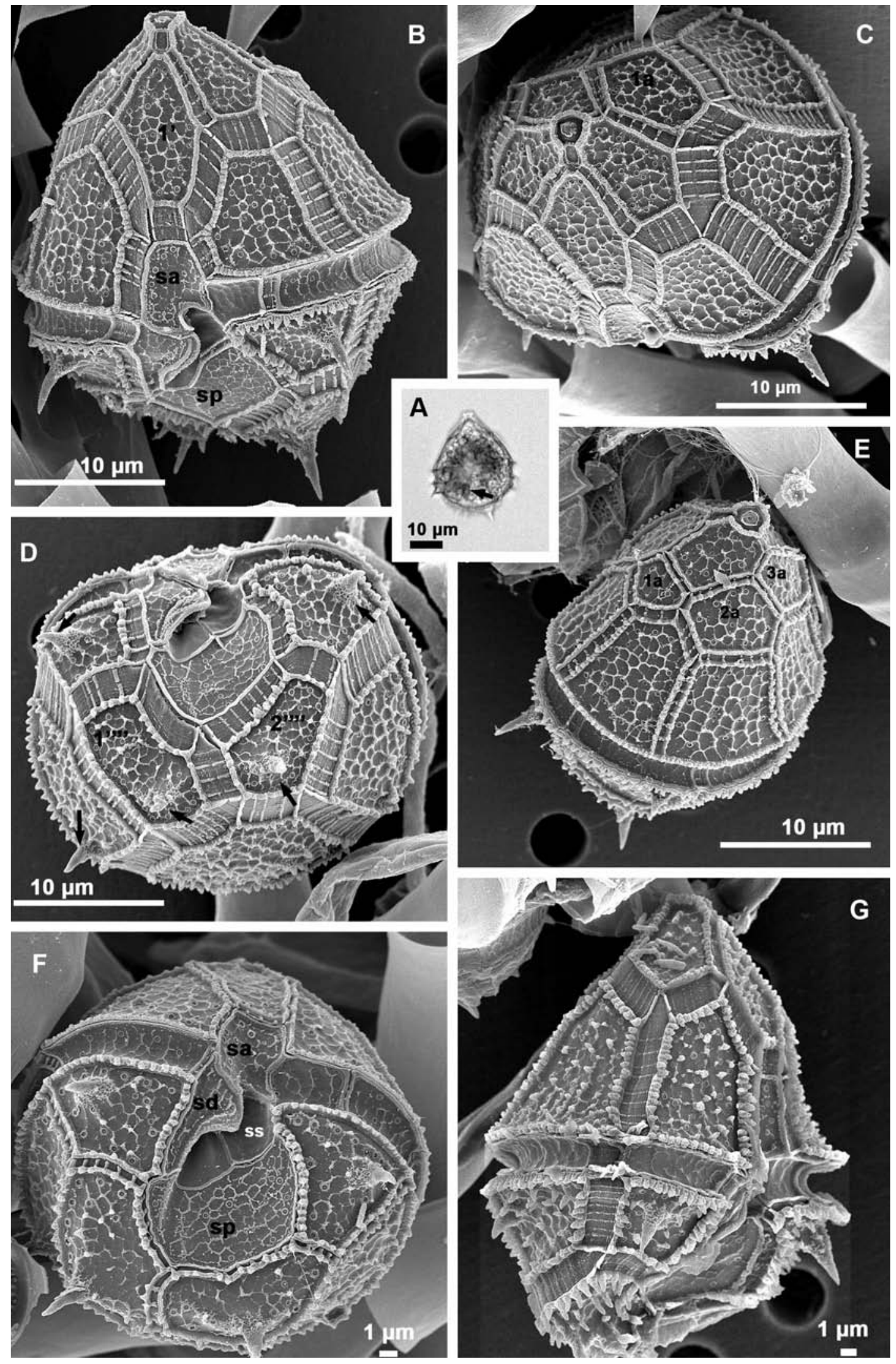

Figs 22A-G. Peridiniopsis cunningtonii. A. Live cell, eyespot (arrow). B-G. SEM. B: ventral view. C: apical view, D: antapical view. Notice antapical spines (arrows), E. Left lateral view of specimen with 3 intercalary plates, F: antapical-ventral view revealing the sulcal plates. G: right lateral view. 

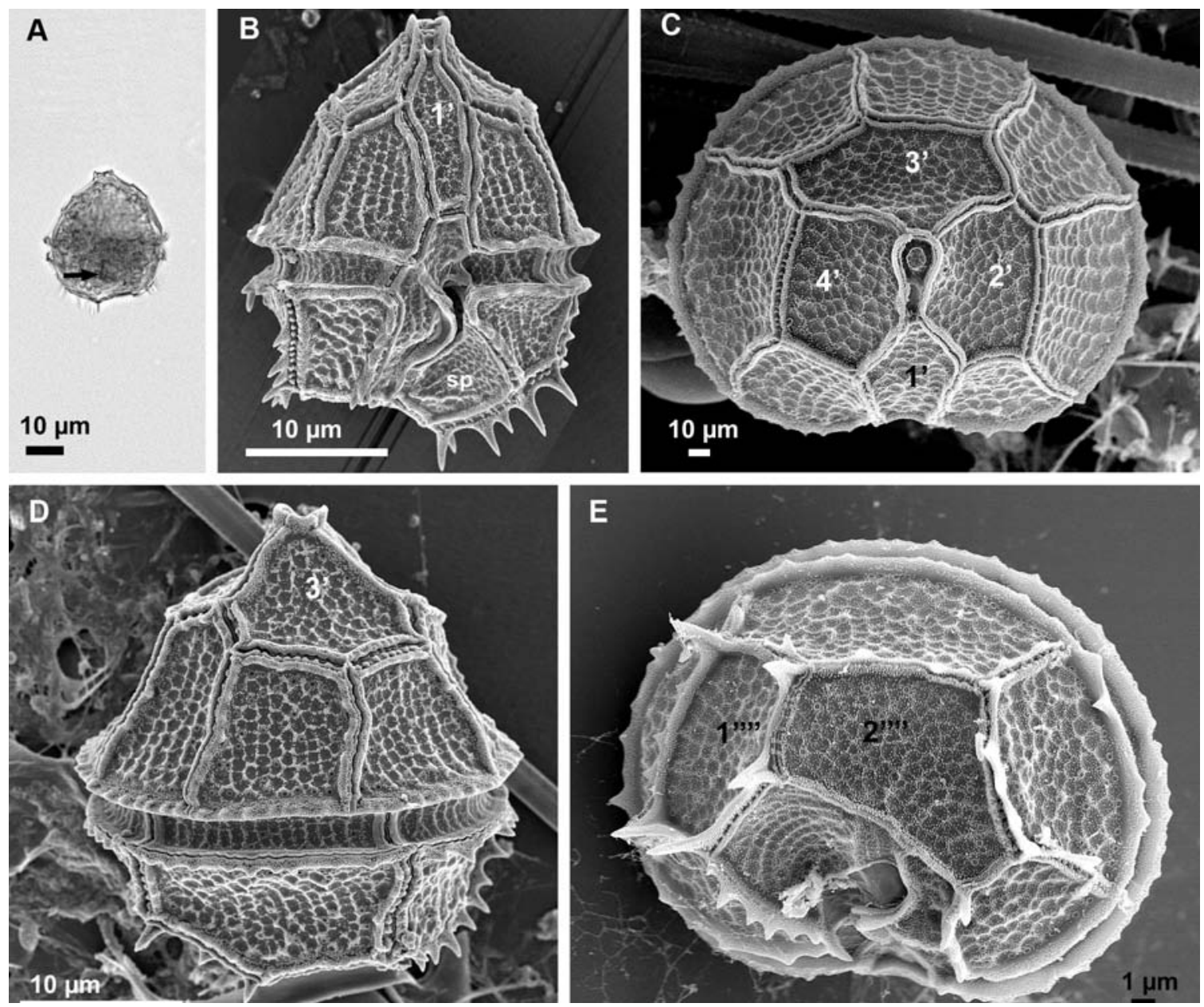

Figs 23A-E. Peridiniopsis elpatiewskyi. A. Live cell, eyespot (arrow). B-E. SEM, B: ventral view, C: apical view, D: dorsal view, E: antapical view.

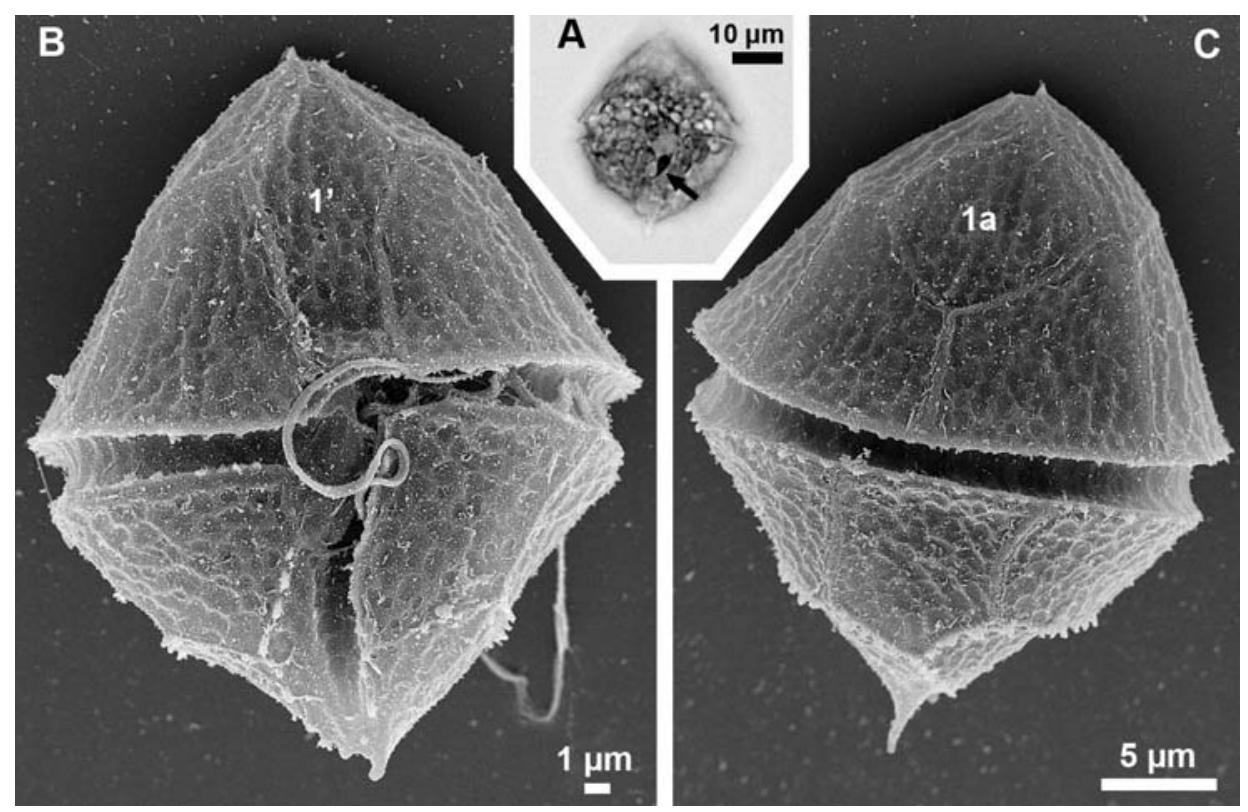

Figs 24A-C. Peridiniopsis kevei. A. Live cell, eyespot (arrow). B, C. SEM, ventral and dorsal views, respectively. 
described in Grigorszky's Ph. D. thesis (Grigorszky 1999). Finally, Krakhmalny (2002) described the same species collected in the Ukraine as $P$. rhombvoides Krakhmalny, also pointing out that it had been described previously in Algologia, 2001 11(4). However, Grigorszky (1999) fulfils the ICBN requirements for description of a new species, such as a Latin diagnosis, designation of a holotype and published in a publication with an ISBN number (ICBN Art 30.5 Note 2, McNeill et al. 2006). The epithet kevei therefore has priority.

Peridiniopsis amazonica Meyer, Rai, et Cronberg is very similar, but this species has two prominent antapical spines and apparently 6 rather than 5 cingular plates (Meyer et al. 1997).

Ultrastructural and molecular analyses have shown that $P$. cf. kevei. has a diatom endosymbiont and an eyespot bound by 3 membranes (Takano et al. 2008).

Peridiniopsis kevei was very abundant in the southern basin of Terlago suggesting it prefers high levels of trophy and conductivity.

\section{Peridiniopsis penardii (Lemmermann) Bourrelly} (Figs 25A-D).

The cell has a conical episome and a rounded or slightly conical hyposome usually with two or more small antapical spines, but cells without spines have been observed. The cingulum is median, only displaced half a cingular width and descending. The cell contains numerous discoid yellowish chloroplasts. A distinct eyespot with an anterior extension is situated in the sulcus. The nucleus is situated in the central part of the cell. The thecal plates typically have no ornamentations but can be reticulated (not shown). The plates are penetrated by scattered pores, though arranged in a regular row at the upper and lower cingular borders. The sa-plate is very small, the sp-plate relatively large. The plate formula is Po, x, 4', 0a, 6", 5c (or t+4c), ?s, 5"', 2"'” (Fukuyo et al. 1990). Length: 23-36 $\mu \mathrm{m}$, width: $23-31 \mu \mathrm{m}$.

Distribution. Ampola (July), Molveno-Bior (July, August).

Comments. Lemmermann (1900b) created the name Glenodinium penardii Lemmermann for a species from Lac Léman referred to as Glenodinium cinctum Ehrenberg by Penard (1891), clearly not $G$. cinctum due to the lack of a horseshoe-shaped eyespot. Later, Lemmermann (1910) provided illustrations of this species now with a distinct plate tabulation and transferred it to the genus Peridinium ( $P$. penardii (Lemmermann) Lemmermann). However, it may be questioned if the species depicted by Lemmermann (1910) is the same as Penard's species from Lac Léman. Penard's material indeed had very distinct yellow discoid chloroplasts, but Penard explicitly described his specimens being surrounded by a thin hyaline and flexible membrane without any plates ('dépourvue de toute trace de facettes'). His illustrations also indicate a very narrow sulcus that extends onto the episome and deflects slightly to the right, quite different from the $P$. penardii illustrated by Lemmermann (1910). Neither Penard nor Lemmermann illustrated or noted the presence of an eyespot, though Penard did mention the presence of red inclusion bodies ('corps rouge') and it could be argued that these were hiding the eyespot. Woloszyńska (1921) described Peridinium andrzejowskii Woloszyńska from lagoons of the River Dniepr as being similar to $P$. penardii except for the right $s b$ plate (plate 2"'") being larger than the left one. In our
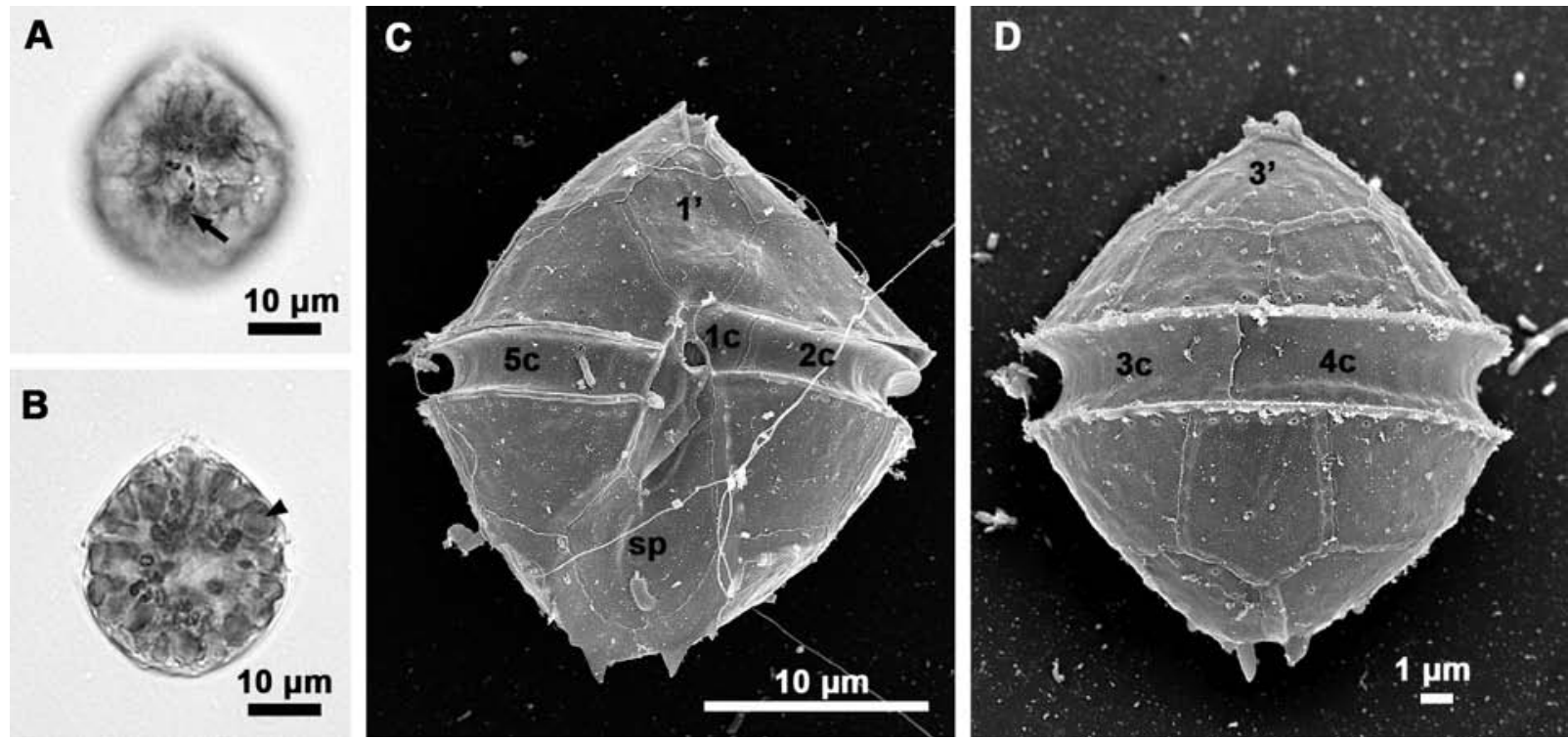

Figs 25A-D. Peridiniopsis penardii. A, B. Live cell, high and low focus, respectively. Notice eyespot with extension (arrow) and discoid chloroplasts (arrowhead). C, D. SEM, ventral and dorsal views, respectively. 
material the 2"'"-plate is usually larger than 1"', but variations may occur, so this character is in our opinion not enough to separate these two species and they are generally considered as synonymous (e.g. HuberPestalozzi 1968). However, andrzejowskii is the nomenclatural correct epithet if Peridiniopsis penardii is not the same as Penard's species. Nevertheless, we propose to keep the name $P$. penardii sensu Lemmermann (1910), as this name is a widely used name for a very common species. Furthermore, it may be argued that Penard (1891) was not able to see the relatively thin plates of this species.

The recently described Peridiniopsis durandii Rodriguez, Couté, Tenhage et Mascarell is distinguished from $P$. penardii by being more rhomboid and having a descending rather than an ascending cingulum (Rodriguez et al. 1999). However, re-examining Lemmermann's (1910, s. 658, fig. 16) illustrations clearly shows that the cingulum is also descending and Lindemann's (1919) illustrations also include a somewhat rhomboid specimens. In the present material we noted variations in cell shape from rhomboid to ovoid, in surface ornamentation - smooth to reticulated and in the numbers of antapical spines. The latter feature was not noted by Penard (1891), Lemmermann (1910), Lindemann (1919) or Woloszyńska (1921), though there seems to be some indication of a spine in Woloszyńska's (1921, fig. 2) drawing. We therefore considered Peridiniopsis durandii a junior synonym of $P$. penardii.

Ultrastructural and molecular analyses have shown that $P$. penardii has a diatom endosymbiont, similar to the symbiont of $P$. kevei, and also an eyespot bound by 3 membranes (Takano et al. 2008).

According to Höll (1928) this species occurs mainly in larger 'anorganotrophic' lakes. Peridiniopsis penardii formed massive summer blooms $\left(10^{7}\right.$ cells/L) in a small lagoon of L. Molveno usually referred to as L. Bior, and in L. Toblino, two hydrologically exploited (and artificially connected) lakes.

\section{Peridiniopsis polonica (Woloszyńska) Bourrelly (Figs 26A-D).}

The cell is dorso-ventrally flattened and the ventral side concave. The episome is rounded or slightly pointed, the hyposome rounded. The cingulum is median and displaced about one cingular width and is descending. A small antapical spine may be present at the left sulcal border. The cell contains numerous yellowish brown discoid chloroplasts. A distinct red eyespot is situated in the sulcus. The nucleus is located in the central part of the cell. The plate formula is: Po, $\mathrm{x}, 4^{\prime}, 2 \mathrm{a}$ (or 1a), 7', 6c (or t+5c), 6s, 5"', 2"' (Fukuyo et al. 1990). The anterior intercalary plates are somewhat square-shaped, the 1a-plate usually is considerably smaller than the 2a-plate. Woloszyńska (1916) depicted specimens with only one anterior intercalary plate. Length: $42-45 \mu \mathrm{m}$, width: $38-40 \mu \mathrm{m}$.
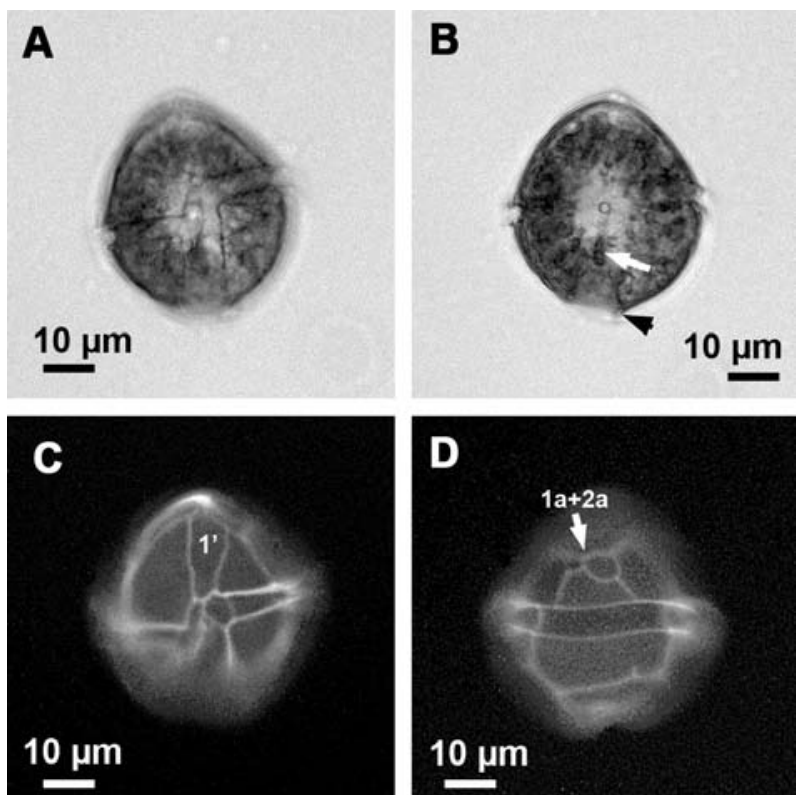

Figs 26A-D. Peridiniopsis polonica. A, B. Live cell, high and low focus, respectively. Notice eyespot (arrow) and antapical spine (arrowhead). C, D. Fluorescence microscopy of CalcoFluor White stained cell, ventral and dorsal views, respectively.

Distribution. Cavedine (July), Santo (August), Terlago South (May).

Comments. This species may produce an ichthyotoxin and has been associated with fish mortality (Oshima et al. 1989).

\section{Peridiniopsis quinquecuspidata (Nygaard)}

\section{Gert Hansen et Flaim comb. nov. (Figs 27A-D).}

This species has a conical episome with an apical horn. The hyposome is considerably smaller than the episome giving the overall cell shape a somewhat triangular appearance. The thecal plates are penetrated by scattered pores bordered with a rim. The hyposomal plates 1"', 2"', 4", 5" and 1"' are each furnished with prominent spine with a hollow basal part. Plate formula: Po, x, 4', 1a, 6", 6c, ?s, 5"', 2'. Length: $26 \mu \mathrm{m}$, width: $21 \mu \mathrm{m}$.

Distribution. Serraia (July, August).

Comments. This species was originally described by Nygaard (1926), as Peridinium cunningtonii Lemmermann var. quinquecuspidata Nygaard. However, Nygaard's species differs considerably from Heterocapsa quinquecuspidata Massart (1920) in the shape of the cells. A distinctive character in Massart's diagnosis was also the presence of a pyrenoid, which was absent in Nygaard's material. It is similar to Peridiniopsis cunningtonii with respect to plate tabulation, but we find it substantially different from this species with respect to cell shape, thecal plate ornamen- 


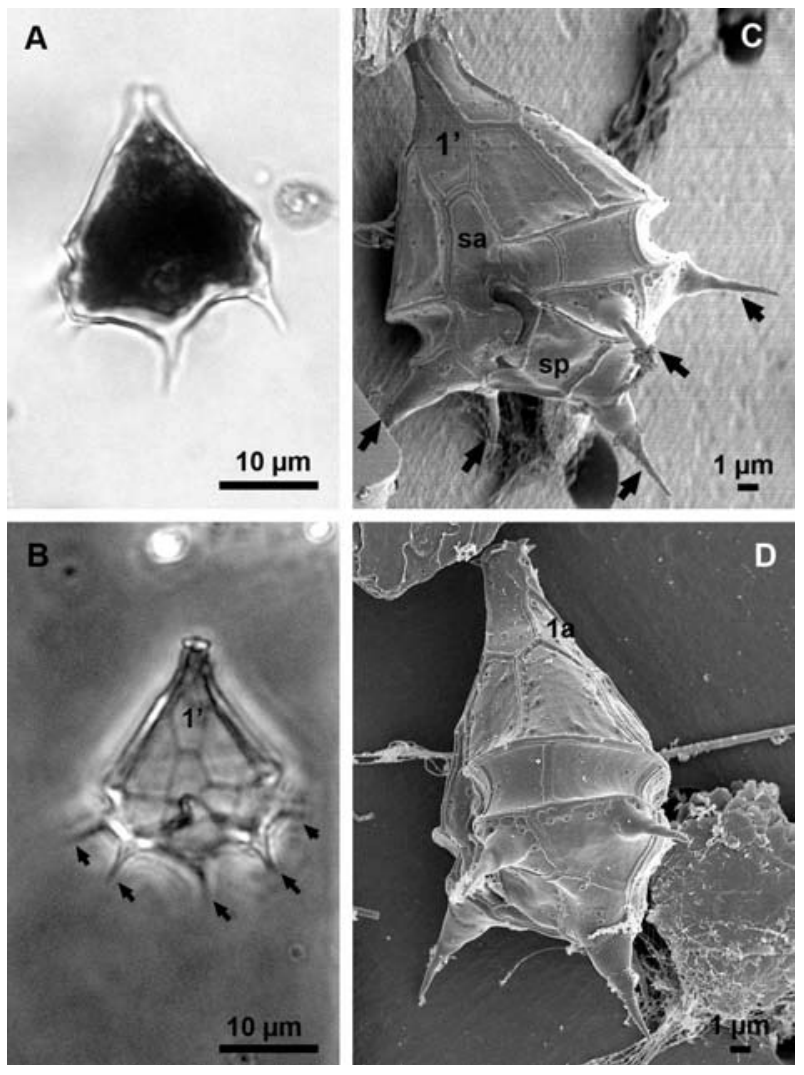

Figs 27A-D. Peridiniopsis quinquecuspidata comb. nov. A, B. LM of fixed cells. The antapical horns are marked by arrows. C, D. SEM, ventral and left lateral views, respectively.

tation and antapical spine structure. We therefore raise this variety to the rank of species:

Peridiniopsis quinquecuspidata (Nygaard) Gert Hansen et Flaim comb. nov, basionym: Peridinium cunningtonii Lemmermann var. quinquecuspidata Nygaard (1926), p. 208-9, pl III fig. 28, following the recommendation of ICBN Art 24B.2 (retaining the final epithet when an infraspecific taxon is raised to the rank of species).

\section{Family Ceratiaceae Willey \& Hickson}

Cells strongly asymmetric with one large apical horn and 2-3 antapical horns. Theca consists of 16-17 thick plates not including cingular and plates. Chloroplasts always present (e.g. Popovský \& Pfiester 1990).

\section{Ceratium cornutum (Ehrenberg) \\ Claparède et Lachmann not illustrated}

A very distinctively-shaped species. The cell is dorso-ventrally flattened with relatively short and robust horns. The apical horn is deflected to the right and its tip is truncate. The ventral side of the cell is concave. Length: $100-150 \mu \mathrm{m}$.

Distribution. Ampola (July), only one specimen.
Comments. According to Huber-Pestalozzi (1968) this species occurs primarily in shallow lakes and prefers colder temperatures. We could only confirm this author's first observation.

\section{Ceratium furcoides (Levander) Langhans (Figs 28A).}

Cells are long and slender. The episome gradually tapers into a long apical horn. The hyposome is furnished with 2-3 antapical horns made up by extensions of the antapical plates. Plate 4' does not reach the apex and is not an apical plate in strict Kofoidean plate terminology. Length: 165-260 $\mu \mathrm{m}$, width: 30-50 $\mu \mathrm{m}$.

Distribution. Serraia (April, May, June, July, August).

Comments. Occurs in oligo- to eutrophic lakes (Popovský \& Pfiester 1990). In eutrophic L. Serraia, it was present from early spring throughout summer.

\section{Ceratium hirundinella (O.F. Müller) Dujardin (Figs 28B).}

Cell body is relatively broad. The episome has a prominent apical horn sharply demarcated from the remainder of the episome. The hyposome is furnished with 2-3 antapical somewhat diverging antapical horns. All 4 apical plates reach the apex. Length: $155-200 \mu \mathrm{m}$, width: $45-63 \mu \mathrm{m}$.
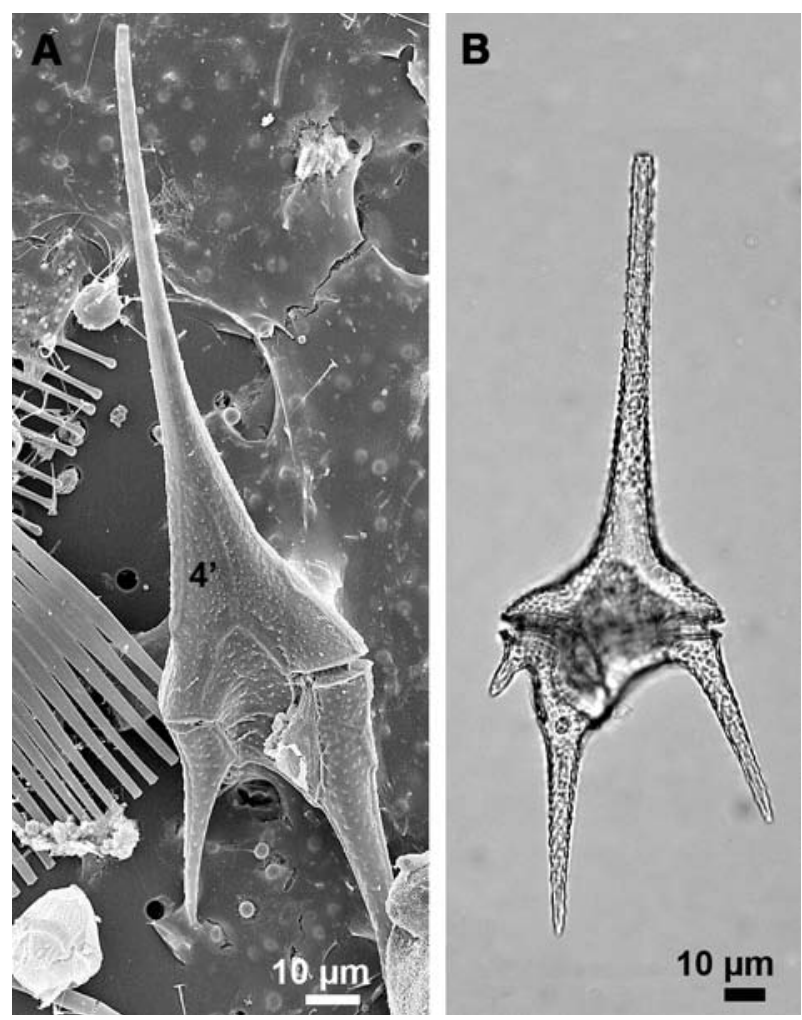

Figs 28A, B. Ceratium. A. C. furcoides (SEM), B. C. hirundinella (LM, fixed cell). 
Distribution. Caldonazzo (May, July), Canzolino (July), Cavedine (July, one empty theca), Lavarone (July), Ledro (July), Levico (May, July), Bior-Molveno (July), Serraia (May), Tenno (July), Terlago North (May, July).

Comments. Ceratium hirundinella has a worldwide distribution, but is often abundant in relatively small oligo-mesotrophic temperate lakes with limited phosphorus levels (Pollingher 1987). It is very form variable and numerous forms and varieties have been described in the literature (see e.g. Huber-Pestalozzi 1968). The presence of 2 or 3 antapical horns appears to be influenced by the water temperature/and or trace metals. Thus, culture studies have shown that individuals with only two antapical horns dominate at $21-25{ }^{\circ} \mathrm{C}$, but 3 horned individuals dominated at $15{ }^{\circ} \mathrm{C}$ (Bruno 1975, cited from Pollingher 1987). In our study, C. hirundinella appeared to be a summer species found in mesoeutrophic lakes.

\section{Incertae sedis}

The family affiliations of the following genera are uncertain.

\section{Baldinia anauniensis Gert Hansen et Daugbjerg (Figs 29A-D).}

The cell is ovoid with hemispherical epi- and hyposome. The cingulum is median and displaced one cingu-
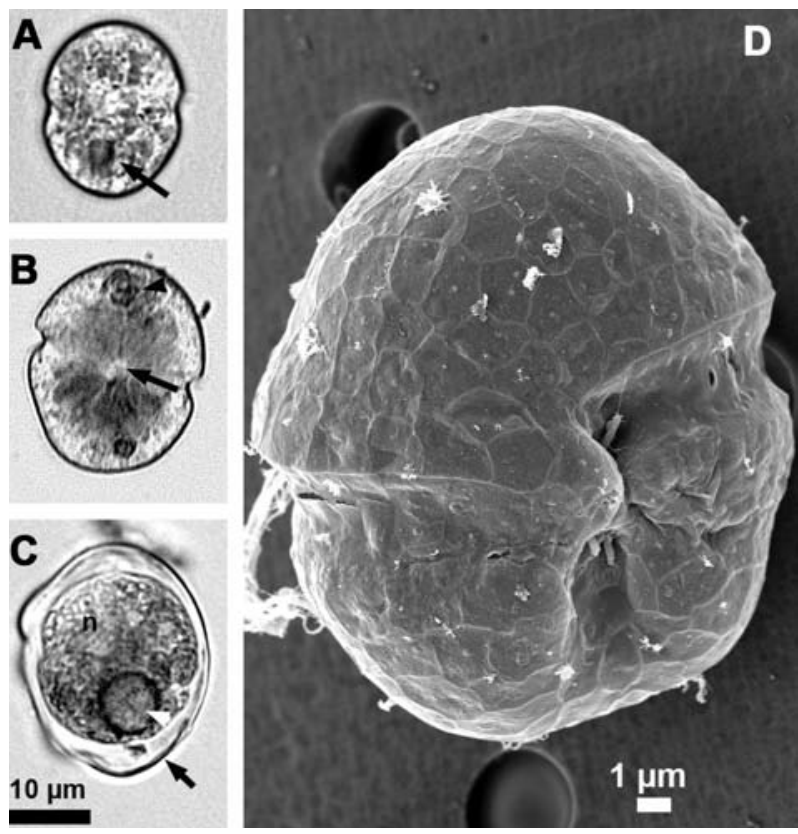

Figs 29A-D. Baldinia anauniensis. A, B. Live cells, notice eyespot (arrow in A), inclusion body (arrowhead) and central pyrenoid (arrow in B). C. Resting cyst, notice the inflated outer cysts wall (arrow) and red accumulation body (arrowhead). D. SEM, ventral view. lar width. The sulcus is narrow and does not reach the antapex. Thecal plates are absent, but the amphiesmal pattern can be seen in SEM. An apical groove or other apical structures are absent. The yellowish green chloroplast(s) radiates from a central pyrenoid. The pyrenoid is of the compound type, but this is only evident in TEM. Often the chloroplast(s) is restricted to the central part of the cell. A red eyespot or stigma is located within the sulcus. The nucleus is located in the central part of the cell (not shown). Red inclusion bodies are usually present in the epi- and/or hyposome. They most likely represent food vacuoles (see below). Length: 23-28 $\mu \mathrm{m}$, width: $18-24 \mu \mathrm{m}$, but small cells (15 $\mu \mathrm{m}$ in length) and large cells (36 $\mu \mathrm{m}$ in length) have occasionally been observed.

The resting cyst is very characteristic. It has an outer smooth and inflated wall, with a truncated apical part and an indented antapical part. The inner wall is thin and closely appressed to the rounded cytoplasmic part. Length: c. $35 \mu \mathrm{m}$, width: c. $28 \mu \mathrm{m}$.

Distribution. Tovel (abundant in June-August samples, but is very common from June to October (Calliari et al. 2006), Santo? (August).

Comments. This species corresponds to Baldi's (1941) 'green form' of 'Glenodinium sanguineum' (see Flaim et al. 2004). However, it is very different from the red form, which now has been named Tovellia sanguinea (see above), and represents a separate species. Due to significantly different ultrastructural- and genetic characteristics compared to other dinoflagellates, it has recently been transferred to the new genus Baldinia (Hansen et al. 2007).

Baldinia anauniensis seems to prefer temperatures above $10^{\circ} \mathrm{C}$, as in diurnal migrations it avoids the cold deeper layers of the lake (Flaim et al. 2003). The species is mixotrophic as food vacuoles with cryptophyte remnants have been observed as well as a retracted feeding tube (peduncle) (Hansen et al. 2007).

A similar morphotype has been observed in L. Santo, but it measured ca. $40 \mu \mathrm{m}$ in length, which is above the upper range found in L. Tovel. Detailed examination like SEM and TEM are needed to confirm this species as B. anauniensis.

\section{Borghiella dodgei Moestrup, Gert Hansen et Daugbjerg (Figs 30A-D).}

The cell is ovoid with a conical or hemispherical episome. The hyposome is usually also hemispherical. The cingulum is median and displaced ca. one cingular width. The nucleus is situated in the central part of the cell. The greenish chloroplast is mesh-shaped and located under the surface of the cell. No stigma is visible. The theca, which is only visible in SEM, consists of numerous polygonal plates and two rows of plates are present within the cingulum. A characteristic apical structure is 

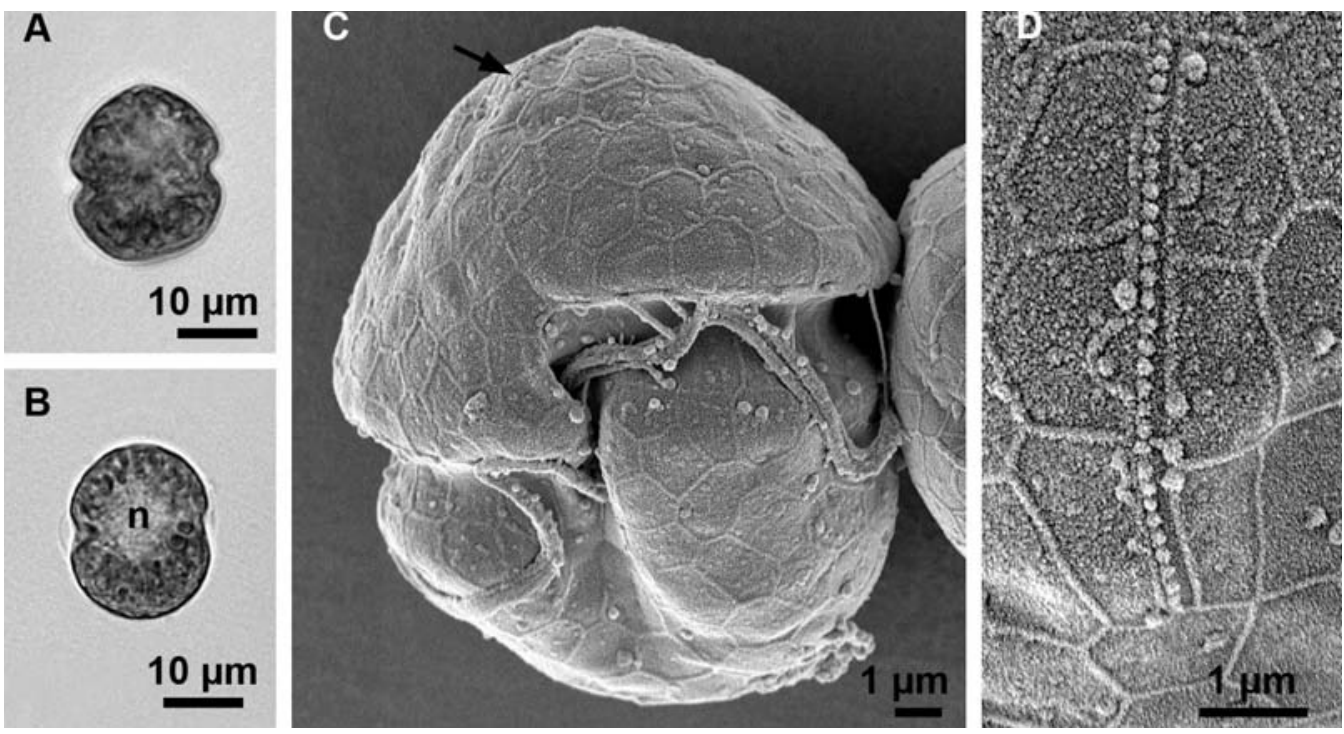

Figs 30A-D. Borghiella dodgei. A, B. LM of live cells. C, D. SEM. C: ventral view. Notice the apical PEV (arrow). D. The PEV at a higher magnification. The single row of knobs on one of the vesicles is evident.

present. It consists of a pair of elongated amphiesmal vesicles $(\mathrm{PEV})$ with numerous knob-like structures. Length: $12-26 \mu \mathrm{m}$, width: $12-22 \mu \mathrm{m}$.

Distribution. Tovel (January? June), can be present from January to June (see Calliari et al. 2006).

Comments. This species corresponds to 'Glenodinium sanguineum' sensu Dodge et al. (1987), but is very different from Tovellia sanguinea, (see above), and represents a separate species. Ultrastructural and genetic data have shown that it should be placed in a genus of its own. Borghiella is characterised by the PEV with associated knobs (Moestrup et al. 2008).

Its temperature preference is well below $10^{\circ} \mathrm{C}$ (Flaim et al. 2004). Most observations of this study were based on a culture based on incubated sediments collected in November 2002 but cells resembling B. dodgei have also been observed in preserved samples collected in January and a small dense coffee-brown patch was observed in early June 2004 (Calliari et al. 2006). Dodge's material was collected in late June, but this seems to be the latest time of the year this species has been observed. It is, however, possible that this species can be present in the colder areas of the lake all year round.

\section{Durinskia occulata}

(Stein) Gert Hansen et Flaim comb. nov. (Figs 31A-G).

The cell is globular or only slightly dorso-ventrally flattened. The cingulum is median and only slightly descending. Numerous small yellowish brown chloroplasts are present near the cell surface. A minute red eyespot is situated in the sulcus. The thecal plates are thin, smooth and penetrated by scattered minute pores, though with a tendency to be situated along the plate margins and/or cingulum. The pore- and canal plate are rather small. The number of cingular plates seems to be 5 . The number of sulcal plates has not been determined, but the anterior sulcal plate (sa) appears to be absent or alternatively the characteristically shaped sd-plate may be hiding the sa. The sp-plate is relatively wide. The 1aplate is small and rhomboid, the 2a-plate large and 6sided. The typical plate formula is Po, x, 4', 2a, 6", 5c, ?s, 5", 2". However, some specimens had only one antapical plate others an extra postcingular plate. Length: 28-34 $\mu \mathrm{m}$, width: 28-34 $\mu \mathrm{m}$.

Distribution. Ampola (July).

Comments. The present material fits well with Stein's (1883) original illustrations of Glenodinium occulatum Stein, with respect to cell shape, chloroplast shape and the minute eyespot. Although, Stein described the 'animal' as being evenly green coloured ('gleichförmig grün gefärbte Tier'), cell or chloroplast colour should be considered with caution. Stein didn't provide any information with respect to plate tabulation, but it may be argued that he overlooked the delicate plates. One of his illustrations indicates that the species was thecate (Stein 1883, Tf. III, fig. 6). The tabulation was later depicted by Woloszyńska (1917) for a species considered to be Peridinium occulatum (Stein) Woloszyńska (=Glenodinium occulatum). The tabulation illustrated by Woloszyńska differs from the present material by having only one 5-sided symmetrically placed anterior intercalary plate and seven rather than 6 precingulars. Furthermore, a canal plate appears to be absent, but it could have been overlooked. Lindemann (1926) illustrated the variations in plate pattern of what he considered to represent Glenodinium occulatum. 

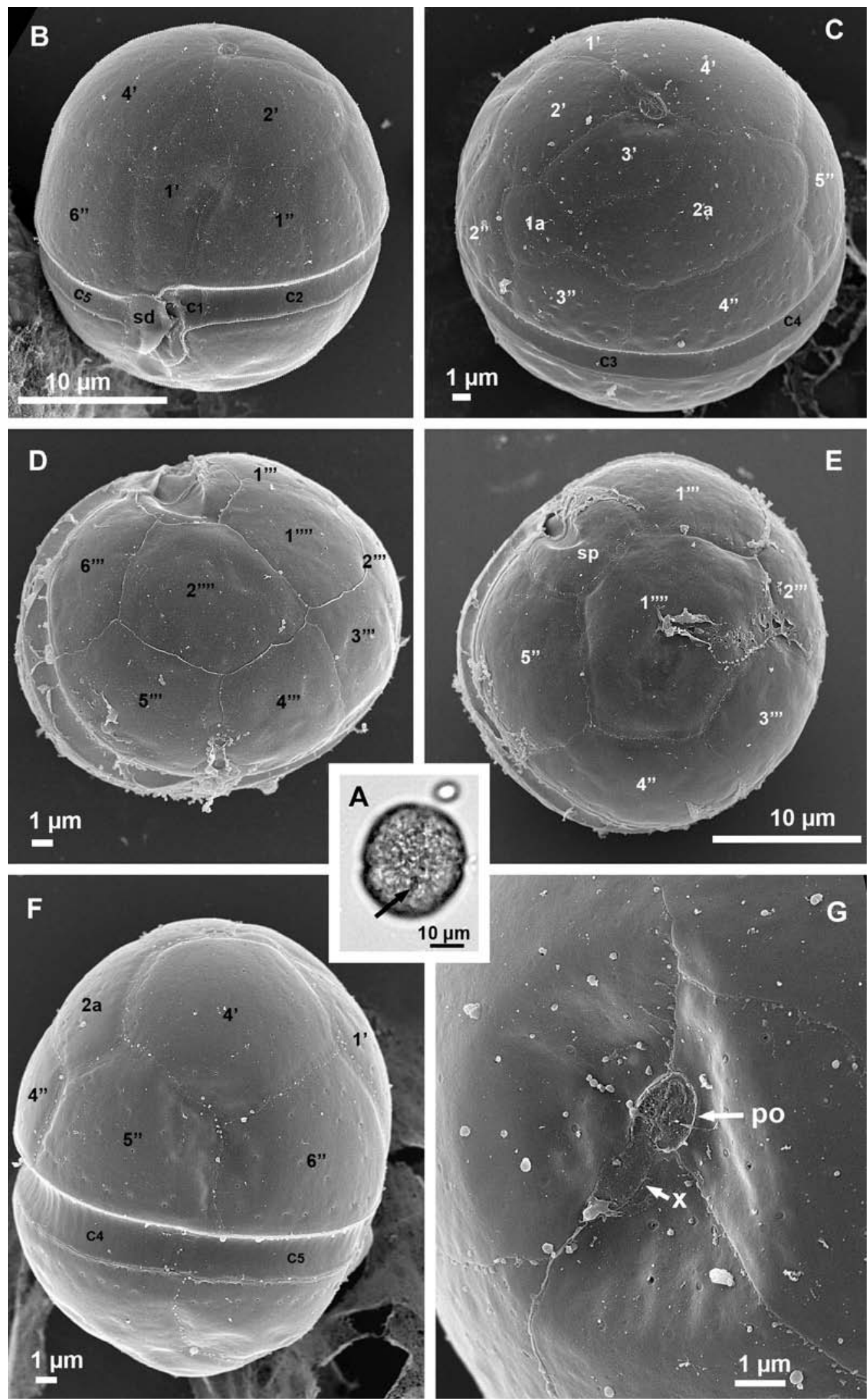

Figs 31A-G. Durinskia occulata comb. nov.. A. Live cell, notice the minute eyespot (arrow). B-G. SEM. B: ventral view, C: apicaldorsal view, D: antapical view, E: antapical view of specimen with only one antapical plate, F: right lateral view, G: the small apical pore (po) and canal plate (x) at a higher magnification. 
Some specimens were in agreement with Woloszyńska's material, but other specimens fit exactly the cells from Ampola, including the presence of a tiny canal plate. Neither Woloszyńska nor Lindemann provided illustrations of the internal part of the cell, making it very uncertain if their material really represents G. occulatum. The tabulation of the present material is similar to Peridinium dybowskii Woloszyńska and Durinskia balti$c a$ (Levander) Carty et Cox, two species that usually are considered to be conspecific (e.g. Schiller 1937, Popovský \& Pfiester 1990). However, Woloszyńska (1916) illustrated the thecal plates of $P$. dybowskii with numerous transversely orientated pores, a feature that is absent in Durinskia baltica. Furthermore, D. baltica usually occurs in brackish waters and harbours a diatom endosymbiont. It is unknown whether or not $P$. dybowskii has an endosymbiont, but it seems to prefer humus rich habitats with low $\mathrm{pH}$ like sphagnum bogs (Höll 1928). Although, the present material fits with $P$. dybowskii with respect to habitat and $D$. baltica with respect to plate ornamentation, it differs by its more globular shape compared to the pronounced dorso-ventral flattening of both $P$. dybowskii and D. baltica. We therefore consider D. occulata, $P$. dybowskii and $D$. baltica as separate species. The recently desribed $D$. capensis Pienaar, Sakai et Horiguchi, which was found in tidal pools, differs from the aforementioned species by a displaced cingulum, partly visible sa-plate and a relatively large 1a-plate (Pienaar et al. 2007). Carty \& Cox (1986) erected the new genus Durinskia to accommodate Peridinium balticum (Levander) Lemmermann, as the plate tabulation of this species fitted neither Peridinium nor Peridiniopsis. We agree with this and make the following new combination:

Durinskia occulata (Stein) Gert Hansen et Flaim comb. nov., basionym Glenodinium occulatum Stein (1883), Taf III, Figs 5-7.

\section{Glochidinium penardiforme (Lemmermann) Boltovskoy (Figs 32A-G).}

The cell is somewhat ovoid and dorso-ventrally flattened. The episome is slightly conical; the hyposome has an antapical indentation. The cingulum is median and not displaced, the sulcus is relatively wide. The nucleus is located in the centre of the cell. Chloroplasts are absent. The thecal plates are furnished with numerous minute knobs or spines. Plate formula: Po, x, 3', 1a, $6 ", 3 \mathrm{c}, 4 \mathrm{~s}, 5$ "', 2". The 1'-plate has a characteristic shape, it is 4-sided (ortho), the 2 anterior sides are considerably shorter than posterior sides and they form a large angle with respect to each other. Another characteristic is the very long C2-plate. Length: $20-30 \mu \mathrm{m}$, width: $20-26 \mu \mathrm{m}$.

Distribution. Caldonazzo (May), Lases (July), Terlago North (May, August), Terlago South (May).
Comments. This species was transferred to the newly erected genus Glochidinium based on the presence of only 3 cingular plates (Boltovskoy 1999). Chloroplasts may be present (e.g. Huber-Pestalozzi 1968) but were never observed in the present material. In our survey, it appeared to be a warm-water species but was never very abundant.

\section{Staszicella dinobryonis Woloszynska (Figs 33A-I).}

The hyposome is usually longer and slightly wider than the episome. Cells often contain a large, and more or less round inclusion body, probably a food vacuole. Chloroplasts appear to be absent, but this observation is based on preserved samples. The thecal plates are thin, smooth and penetrated by minute pores. The plate formula is Po, x, 5', 1a, 7", 6c, 5s?, 5"', 2"'”. The 1'-plate is usually very narrow though there may be some variations of this feature. The pore plate often seems to lack a pore opening. The $\mathrm{C} 1$ plate is narrow and the 2a-plate small and rhomboid. The sd-plate has a distinct left protrusion and the sp-plate is relatively narrow. Length: 19$23 \mu \mathrm{m}$, width: $18-23 \mu \mathrm{m}$.

Distribution. Caldonazzo (March, May, July), Canzolino (March, May), Columba? (July), Lases (March, July), Lavarone (April), Levico (July), Madrano (March), Santo (March), Terlago North (March, May), Terlago South (March), Tovel (January, April, June, July).

Comments. Woloszyńska (1916) noted that cells often were attached to Dinobryon colonies. We didn't observe this in the present material, but cells may have become detached during fixation. Dinobryon spp. were present in the samples. The original description is not very explicit with respect to the presence of chloroplasts and eyespot. According to Skuja (1956) this species has numerous small disc-shaped chloroplasts but lacks an eyespot, though it is not possible based on Skuja's illustrations to verify if his specimen is $S$. dinobryonis. Variation in epithecal tabulation may occur. Thus, Woloszyńska (1917) illustrated a specimen with 8 rather than 7 precingular plates, despite claiming that plate tabulation was constant for this species. Lindemann (1926) also depicted variations of the epithecal plate pattern, 6 or 7 precingular plates and from 1-3 anterior intercalary plates. However, the minute apical poreplate in Lindemann's material indicates that it may represent another species. We observed a cell, presumably representing this species, with 3 anterior intercalary plates in a sample from L. Colomba. Woloszyńska (1916) created the monospecific genus Staszicella for this species due to its smaller epi- than hyposome. Bourrelly (1968) transferred it to the genus Peridiniopsis due to the presence of only one anterior intecalary plate (see above). However, we find the plate pattern of this species different enough from the type species Peridiniopsis borgei Lemmermann to warrant its own genus. 

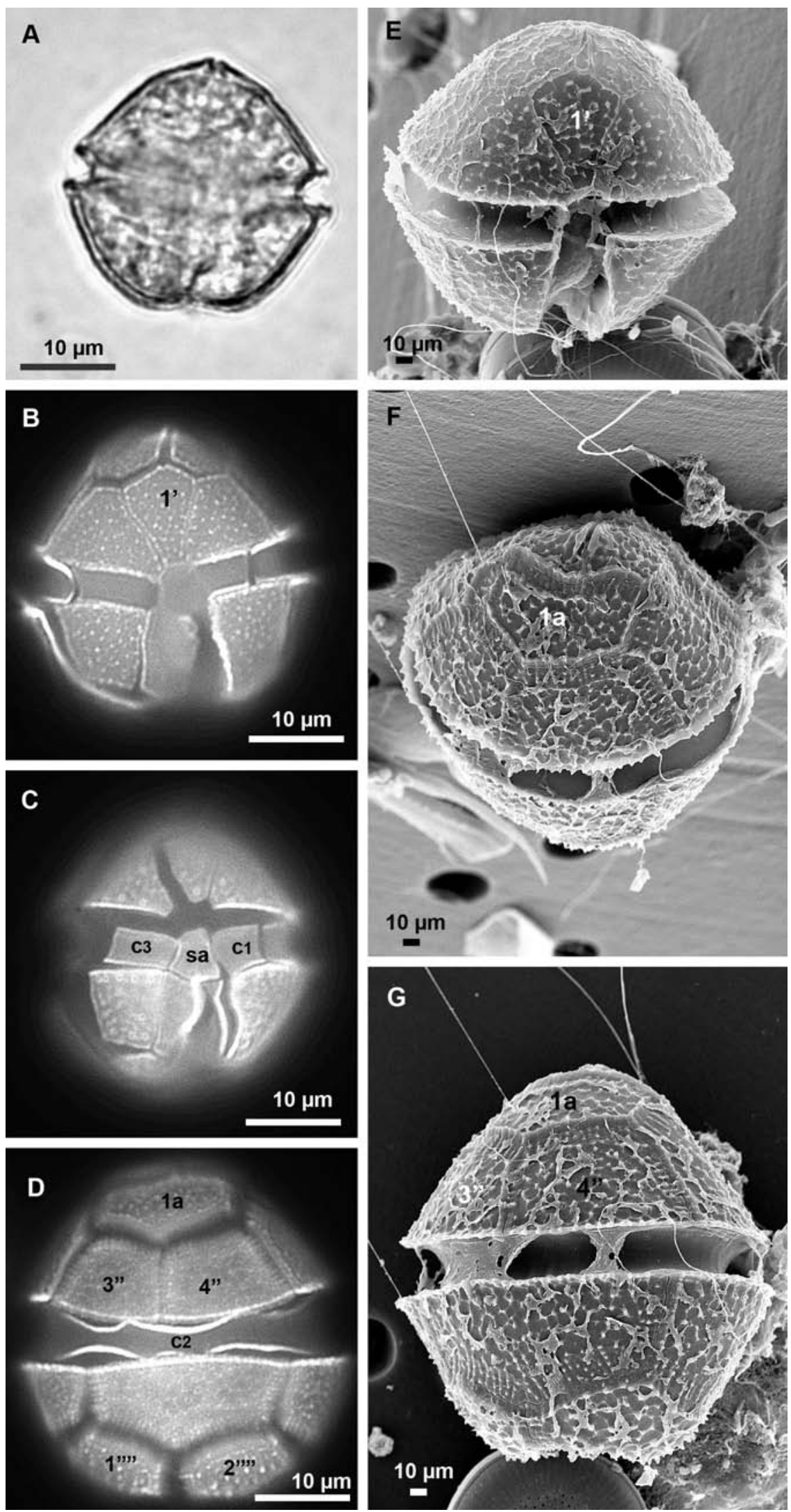

Figs 32A-G. Glochidinium penardiforme. A. Fixed cell (LM). B-D. Fluorescence microscopy of CalcoFluor White stained cells. EG. SEM. E: ventral view, F: apical view, G: dorsal view. 

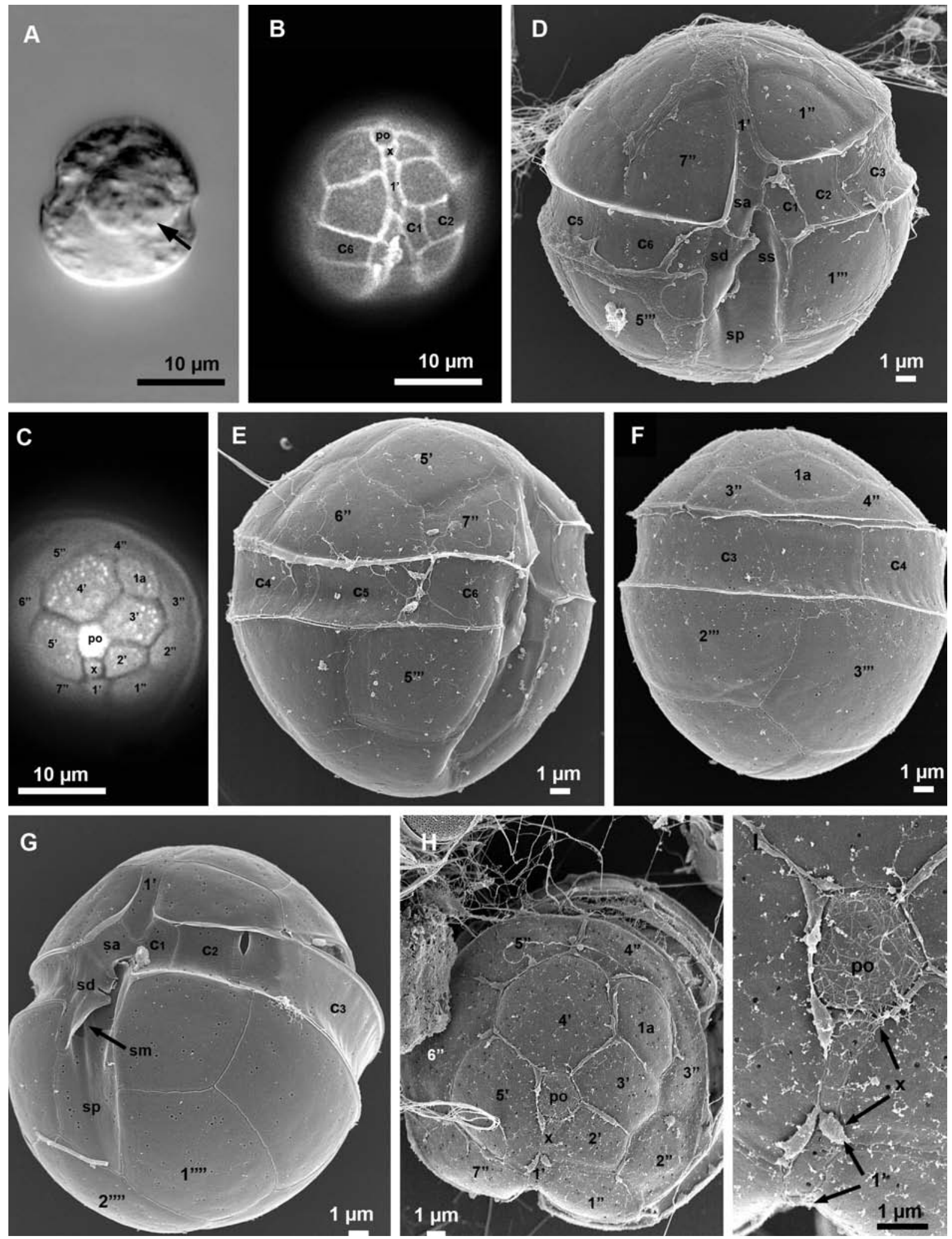

Figs 33A-I. Staszicella dinobryonis. A. Fixed cell, notice putative food vacuoles (arrow) (LM). B-C. Fluorescence microscopy of CalcoFluor White stained cells. D-I. SEM. D: ventral view, E: right lateral view, F: left lateral view, G: antapical-ventral view, H: apical view, I: pore- and canal plate at a higher magnification. Notice po lacks an opening. 


\section{ACKNOWLEDGEMENTS}

The authors thank Prof. Antonella Inama for the Latin translations, Vigilio Pinamonti and Gino Leonardi for some of the samples and Prof. Øjvind Moestrup and Karin Lindberg for critical reading of the manuscript. Dr. Andrzej Witkowski and Dr. István Grigorszky are thanked for translation of Polish and Hungarian texts. GH thanks Dr. Antonio Calado for valuable discussions and advice on nomenclatural issues, and Lisbet, Julie and Tobias Bøllingtoft for their tireless help with sampling. This study was financed by the Carlsberg Foundation (to GH) and the ECOPLAN/SALTO Project - Province Trento (Italy).

\section{REFERENCES}

Allmann, G.J. 1854. Communication to the Irish Royal Academy. Proc. Royal. Irish Acad., 6: 115-120.

Allmann, G.J. 1855. Observations on Aphanizomenon flosaquae, and a species of Peridinea. Quarterly J. Micros. Sci., 3: 21-25, Pl. III.

Alster, A., Z. Dubinsky \& T. Zohary. 2006. Encystment of Peridinium gatunense: occurrence, favourable environmental conditions and its role in the dinoflagellate life cycle in a subtropical lake. Freshwater Biology, 51: $1219-1228$

Balech, E. 1974. El genero 'Protoperidinium' Bergh, 1981 ('Peridinium' Ehrenberg, 1831, partim). Rev. Mus. Arg. Cienc. Nat. 'Bernadino Revista', Hydrobiolgia, 4: 1-79.

Balech, E. 1980. On thecal morphology of dinoflagellates with special emphasis on cingular and sulcal plates. An. Centro Cien. Mar Limnol. Univ. Autón. Mexico, 7: 57-68.

Baldi, E. 1941. Ricerche idrobiologiche sul lago di Tovel. Mem. Mus. Storia Nat. Venezia Tridentina, 6: 1-297.

Boltovskoy, A. 1999. The genus Glochidinium gen. nov., with two species: G. penardiforme comb. nov. and G. platygaster sp. nov. Grana, 38: 98-107.

Borghi, B., A. Borsato, M. Cantonati, F. Corradini \& G. Flaim, 2006. Studio sul mancato arrossamento del Lago di Tovel. Studi Trentini Sci. Nat. 81(2004) suppl 2: 1-476.

Bourrelly, P. 1968. Notes sur les Péridiniens d'éau douce. Protistologica, 4: 5-16.

Bourrelly, P. 1970. Les Algues d'eau douce. Tome III. Les Algues bleues et rouges. Les Eugleniens, Peridiniens et Cryptomonadines. N. Boubée \& Cie, Paris: 512 pp.

Bruno, S.F. 1975. Cultural studies on the ecology of Ceratium hirundinella (OFM) Bergh, with notes on cyclomorphsis. $\mathrm{Ph}$. D. Thesis, Fordham Univ.

Calado, A. \& Ø. Moestrup. 1997. Feeding in Peridiniopsis berolinensis (Dinophyceae): new observations on tube feeding by an omnivorous, heterotrophic dinoflagellate. Phycologia, 36: 47-59.

Calliari, D., F. Corradini \& G. Flaim. 2006. Dinoflagellate diversity in Lake Tovel. Stud. Trentini Sci. Nat., Acta Biologica 81 (2004) Suppl. 2: 351-355.

Carty, S. 1989. Thompsodinium and two species of Peridiniopsis (Dinophyceae): Taxonomic notes based on scanning electron microscopy. Trans. Am. Microsc. Soc., 108: 64-73.

Carty, S. \& E.R. Cox. 1986. Kansodinium gen. nov. and Durinskia gen. nov.: two genera of freshwater dinoflagellates (Pyrrhophyta). Phycologia, 25: 197-204.

Cavalca, L., P. Ferrari \& V. Andreoni. 2001. Glenodinium san- guineum March. and the reddening phenomenon of Lake Tovel. Annals Microbiol. 51: 159-177.

Claparède, E. \& J. Lachmann. 1859. Etudes sur les Infusoires et les Rhizopodes. Ordre III. Infusoires Cilioflagellés. Mem. Inst. Nat. Genevois, 6: 392-412.

Corradini, F., G. Flaim \& V. Pinamonti. 2001. Five years of limnological observations on lake Tovel (1995-1999): some considerations and comparisons with past data. Atti dell'Ass. Ital. Oceanogr. Limnol., 14: 209-218.

Daugbjerg, N., G. Hansen, J. Larsen \& Ø. Moestrup. 2000. Phylogeny of some of the major genera of dinoflagellates based on ultrastructure and partial LSU rDNA sequence data, including the erection of three new genera of unarmoured dinoflagellates. Phycologia, 39: 302-317.

Dodge, J.D., P. Mariani, A. Paganelli \& R. Trevisan. 1987. Fine structure of the red-bloom dinoflagellate Glenodinium sanguineum from Lake Tovel (N. Italy). Algol. Stud., 47: 125138.

Ehrenberg, C.G. 1838. Die Infusionstiere als vollkommene Organismen. Voss, Berlin und Leipzig: 546 pp.

Elbrächter, M. \& B. Meyer. 2001. Plate pattern variability and plate overlap in a clonal culture of the freshwater dinoflagellate Peridinium umbonatum Stein species complex (Dinophyceae). N. Jb. Geol. Paläont. Abh., 219: 221-227.

Flaim, G., E. Rott, F. Corradini, G. Toller \& B. Borghi. 2003. Long-term trends in species composition and diurnal migration of dinoflagellates in Lake Tovel (Trentino, Italy). Hydrobiologia, 502: 357-366.

Flaim, G., G. Hansen, Ø. Moestrup, F. Corradini. \& B. Borghi. 2004. Reinterpretation of the dinoflagellate 'Glenodinium sanguineum' in the reddening of Lake Tovel, Italian Alps. Phycologia, 43: 737-743.

Fritz, L. \& R.E. Triemer. 1985. A rapid simple technique utilizing CalcoFluor White M2R for the visualization of dinoflagellate thecal plates. J. Phycol., 21: 662-666.

Fukuyo, Y., H. Takano, M. Chihara \& K. Matsuoka. 1990. Red tide organisms in Japan. An illustrated taxonomic guide. Uchida Rokakuho, Tokyo, Japan: 407 pp.

Grigorszky, I. 1999. A magyarországi Dinophyta fajok taxonómiájának, chorológiájának és ökológiájának vizsgálata. Kossuth Egyetemi Kiadó, Debrecen: 143 pp.

Grigorszky, I., F. Vasas, G. Borics, R. Klee, A. Schmidt \& G. Borbély. 2001. Peridiniopsis kevei sp. nov., a new freshwater dinoflagellate species (Peridiniaceae, Dinophyta) from Hungary. Acta Bot. Hung., 43: 163-174.

Hansen, G., Ø. Moestrup \& K.R. Roberts. 2000. Light and electron microscopical observations on the type species of Gymnodinium, G. fuscum (Dinophyceae). Phycologia, 39: 365-376.

Hansen, G., N. Daugbjerg \& P. Henriksen. 2007. Baldinia anauniensis gen. et sp. nov. a 'new' dinoflagellate from Lake Tovel. Phycologia, 46: 86-108.

Highfill, J.F. \& L.A. Pfiester. 1992. The ultrastructure of Glenodiopsis steinii (Dinophyceae). Am. J. Bot., 79: 1162-1170.

Huber-Pestalozzi, G. 1968. Das Phytoplankton des Süsswassers. Cryptophyceen, Chloromonadineen, Peridineen. Die Binnengewässer, 16(3): 322 pp.

Höll, K. 1928. Öekologie der Peridineen. Pflanzenforschung, 11: 1-105.

IASMA 1996-1999. Limnological characteristics of Trentino lakes. Istituto Agrario di S. Michele all'Adige.TN Annual Reports (in Italian).

Kisselev, J.A. 1954. Pirofitovye vodorosli. Opredelitel presnovod. vodoroslej, 6: 1-212.

Krakhmalny, A.F. 2002. A new species of the genus Peridiniopsis Lemm. (Peridiniales, Dinophyta). Int. J. Algae, 4: 51-58.

Lauterborn, R. 1896. Diagnosen neuer Protozoen aus dem Gebiete des Oberrheins. Zool. Anzeiger, 19: 14-18.

Lefèvre, M. 1932. Monographie des espècies d'eau douce du genre Peridinium. Arch. Bot., 2(5): 1-210. 
Leitao, M., L. Ten-Hage, G. Mascarell \& A. Couté, 2001. Peridiniopsis corillionii sp. nova (Dinophyta), une nouvelle dinophycée d'eau douce de France responsible de marées rouges en rivière. Algol. Stud., 102: 1-15.

Lemmermann, E. 1900a. Ergebnisse einer Reise nach dem Pacific. Planktonalgen. Abh. Naturw. Ver. Bremen, 16: 313-398.

Lemmermann, E. 1900b. Beiträge zur kenntniss der Planktonalgen. VIII. Peridiniales aquae dulcis et submarinae. Hedwigia, 29: 8-121.

Lemmermann, E. 1910. Algen I (Schizophyceen, Flagellaten, Peridineen). III. Klasse. Peridiniales. Kryptogamen Flora der Mark Brandenburg, 3: 563-686.

Lindberg, K., Ø. Moestrup \& N. Daugbjerg. 2005. Studies on woloszynskioid dinoflagellates I: Woloszynskia coronata re-examined using light and electron microscopy and partial LSU rDNA sequences, with description of Tovellia gen. nov. and Jadwigia gen. nov. (Tovelliaceae fam. nov.). Phycologia, 44: 416-440.

Lindemann, E. 1919. Untersuchungen über Süsswasserperidineen und ihre Variationsformen. Arch. Protistenkd., 39: 209-261.

Lindemann, E. 1925. Peridíneen des Oberrheins und seiner Altwässer. Zeitschr.f. gesamte Bot., 11: 474-481.

Lindemann, E. 1926. Bewegeliche Hüllenfelderung und ihr Einfluss auf die Frage der Artbildung bei Glenodinien. Arch.f. Hydrobiol., 16: 437-458.

Lindemann, E. 1928a. Peridineae (Dinoflagellatae) In: Engler, A. \& Prantl, K. (Eds), Die natürlichen Pflanzenfamilien, 2. Aufl., Bd. 2. Engelmann, Leipzig: 13-104.

Lindemann, E. 1928b. Vorläufige Mitteilung. Arch. Protistenkd., 63: 259-260.

Lindström, K. 1984. Effect of temperature, light and pH on the growth, photosynthesis, and respiration of the dinoflagellate Peridinium cinctum fa. westii in laboratory cultures. $J$ Phycol., 20: 212-220.

Lindström, K. 1991. Nutrient requirements of the dinoflagellate Peridinium gatunense. J. Phycol., 27: 207-219.

Logares, R., K. Rengefors, A. Kremp, K. Shalchian-Tabrizi, A. Boltovskoy, T. Tengs, A. Shurtleff \& D. Klaveness. 2007. Phenotypically different microalgal morphospecies with identical ribosomal DNA: A case of rapid adaptive evolution? Microb. Ecol., 53: 549-561.

Massart, J. 1920. Recherches sur les organismes inférieurs. VIII. Sur la motilité des flagellates. Acad. Roy. de Belgique, Bull., Classe de Sciences 5. Ser, T. VI: 116-141.

McNeill, J., F.R. Barrie, H.M. Burdet, V. Demoulin, D.L. Hawksworth, K. Marhold, D.H. Nicolson, J. Prado, P.C. Silva, J.E. Skog, \& J.H. Wiersema. 2006. International Code of Botanical Nomenclature (Vienna Code). Regnum Vegetabile 146. A.R.G. Gantner Verlag KG, Ruggell: $568 \mathrm{pp}$.

Meyer, B. \& M. Elbrächter. 1996. Proposal to conserve the name Peridinium elpatiewskyi (Dinophyceae) with a conserved type. Taxon, 45: 531-532.

Meyer, B., H. Rai. \& G. Cronberg. 1997. The thecal structure of Peridiniopsis amazonica spec. nov. (Dinophyceae), a new cyst-producing freshwater dinoflagellate from Amazonian floodplain lakes. Nova Hedwigia, 65: 365-375.

Moestrup, $\varnothing \&$ N. Daugbjerg. 2007. On dinoflagellate phylogeny and classification. In: J. Brodie, \& J. Lewis, J. (Eds), Unravelling the Algae: The Past, Present, and Future of Algae Systematics. Systematics Association Special Volumes, vol 75, CRC Press, Boca Raton: 215-230.

Moestrup, Ø., G. Hansen, G. Daugbjerg, N. Flaim, \& M. D'Andrea. 2006. Studies on woloszynskioid dinoflagellates II: On Tovellia sanguinea sp. nov., the dinoflagellate responsible for the reddening of Lake Tovel, N. Italy. Eur. J. Phycol., 41: 47-65.

Moestrup, Ø., G. Hansen \& N. Daugbjerg. 2008. Studies on woloszynskioid dinoflagellates III: On Borghiella gen. nov., and $B$. dodgei sp. nov., a cold-water species from Lago di Tovel, N. Italy, and on B. tenuissima comb. nov. (syn. Woloszynskia tenuissima). Phycologia, 47: 54-78.

Nygaard, G. 1926. Plankton from two lakes of the Malayan region. Vidensk. Medd. Dansk. naturh. Foren, 82: 197-240, Pl. 1-8.

Nygaard, G. 1949. Hydrobiological studies on some Danish ponds and lakes. Part II. The quotient hypothesis and some new or little known phytoplankton organisms. Det Kongelige Danske Videnskabernes Selskab, Biol. Skr., 7(1): 1-293.

Olrik, K. 1992. Ecology of Peridinium willei and P. volzii (Dinophyceae) in Danish lakes. Nord. J. Bot., 2: 557-568.

Oshima, Y., H. Minami, Y. Takano \& T. Yasumoto. 1989. Ichthyotoxins in a freshwater dinoflagellate Peridinium polonicum. In: T. Okaichi, D.M. Anderson \& T. Nemoto (Eds), Red tides: biology, environmental science and toxicology. Elsevier Sci. Publ., N.Y.: 375-378.

Penard, E. 1891. Les Péridiniacées du Léman. Bull. Trav. Soc. Bot. Genève, 6: 1-63, $5 \mathrm{pl}$.

Pienaar, R.N., H. Sakai \& T. Horiguchi. 2007. Description of a new dinoflagellate with a diatom endosymbiont, Durinskia capensis sp. nov. (Peridiniales, Dinophyceae) from South Africa. J. Plant Res., 120: 247-258.

Pollingher, U. 1987. Freshwater ecosystems. In: F.J.R. Taylor (Ed.), The biology of the dinoflagellates. Bot. Monographs, 21: 502-529.

Popovský, J. 1982. Another case of phagotrophy by Gymnodinium helveticum Penard f. achroum Skuja. Arch. Protistenk., 125: 73-78.

Popovský, J. \& L.A. Pfiester. 1990. Dinophyceae (Dinoflagellida) In: H. Ettl, J. Gerloff, H. Heynig \& D. Mollenhauer (Eds), Süsswasserflora von Mitteleuropa begründet von A. Pascher, Gustav Fischer Verlag, Jena: 272 pp.

Rengefors, K. \& C. Legrand. 2001. Toxicity in Peridinium aciculiferum - an adaptive strategy to outcompete other winter phytoplankton? Limnol. Oceanogr., 46: 1990-1997.

Rodriguez, S., A. Couté, L. Ten-Hage \& G. Mascarell. 1999. Peridiniopsis durandi sp. nova (Dinophyta), une nouvelle Dinophycée d'eau douce responsible de marées rouges. Algol. Stud., 95: 15-29.

Saldarriaga, J.F., F.J.R. Taylor, T. Cavalier-Smith, S. MendenDeuer \& P.J. Keeling. 2004. Molecular data and the evolutionary history of dinoflagellates. Eur. J. Protistol., 40: 85-111.

Schiller, J. 1933. Dinoflagellatae. I. In: Rabenhorsts Kryptogamenflora, 10(3): $617 \mathrm{pp.}$

Schiller, J. 1937. Dinoflagellatae. II. In: Rabenhorsts Kryptogamenflora, 10(3): 590 pp.

Schilling, A.J. 1891. Die Süsswasser-Peridineen. UniversitätsBuchdruckerei (R. Friedrich), Marburg: $81 \mathrm{pp}$.

Schnepf, E., S. Winter \& D. Mollenhauer. 1989. Gymnodinium aeruginosum (Dinophyta): a blue-green dinoflagellate with a vestigial, anucleate, cryptophycean endosymbiont. $\mathrm{Pl}$. Syst. Evol. 164: 75-91.

Senzaki, S. \& T. Horiguchi. 1994. A taxonomic survey of freshwater dinoflagellates of Nagano Prefecture, Japan. Jpn. J. Phycol., 42: 29-42.

Skuja, H. 1948. Taxonomie des Phytoplanktons einiger Seen in Uppland, Schweden. Symbolae Bot. Upsalienses, 9: 1-399, Pl. 1-39.

Skuja, H. 1956. Taxonomische und biologische Studien über das Phytoplankton schwedischer Binnengewässer. Nova Acta Reg. Soci. Sci. Upsal., Ser. IV, 16: 1-404.

Stein, F.R. von 1883. Der Organismus der Infusionsthiere nach eigenen Forschungen in systematischer Reienfolge bearbeitet. III. Abteilung. II. Hälfte. Die Naturgeschichte der arthrodelen Flagellaten. Wilhelm Engelmann: 30 pp., $25 \mathrm{Pl}$.

Takano, Y. \& T. Horiguchi. 2004. Surface ultrastructure and molecular phylogenetics of four unarmored heterotrophic dinoflagellates, including the type species of the genus Gyrodinium (Dinophyceae). Phycol. Res., 52: 107-116. 
Takano, Y., G. Hansen, D. Fujita \& T. Horiguchi. 2008. Serial replacement of diatom endosymbionts in two freshwater dinoflagellates, Peridiniopsis spp. (Peridiniales, Dinophyceae). Phycologia, 47: 41-53.

Tomasi, G. 2004. I trecento laghi del Trentino. Artimedia Casa Editrice. Trento: $535 \mathrm{pp}$.

Utermöhl, H. 1925. Limnologiche Phytoplanktonstudien. Die Besiedelung Ostholsteinischer Seen mit Swebpflanzen. Arch. Hydrobiol., Suppl. 5: 1-527.

Woloszyńska, J. 1916. Polnische Süsswasser-Peridineen. Bull. Int. Acad. Sci. Crocovie Ser. B 1915: 260-285.

Received: August 2007

Accepted: December 2007
Woloszyńska, J. 1917. Neue Peridineen-Arten, nebst Bemerkungen über den Bau der Hülle bei Gymno- und Glenodinium. Bull. Int. Acad. Sci. Crocovie Ser. B: 114122, Pl. 11-13.

Woloszyńska, J. 1921. Glony okolic Kijowa. Rozpr. Wydz. mat.-Przyr. Polsk. Akad. Umiej. ser. 3., 20B: 127-140.

Woloszyńska, J. 1952. Peridineae montium Tatrensium et Carpathorum Orientalium. Acta Soc. Bot. Poloniae, 21: 311-316. 